\title{
DIVERSIDADE GENÉTICA DE ENTEROBACTÉRIAS ENDOFÍTICAS DE DIFERENTES HOSPEDEIROS E COLONIZAÇÃO DE Catharantus roseus POR ENDÓFITOS EXPRESSANDO O GENE gfp
}

\author{
AdALGISA RIBEIRO TORRES
}

Tese apresentada à Escola Superior de Agricultura "Luiz de Queiroz", Universidade de São Paulo, para obtenção do título de Doutor em Agronomia, Área de Concentração: Genética e Melhoramento de Plantas.

PIRA CICAB A

Estado de São Paulo - Brasil

Fevereiro - 2005 


\title{
DIVERSIDADE GENÉTICA DE ENTEROBACTÉRIAS ENDOFITICAS DE DIFERENTES HOSPEDEIROS E COLONIZAÇÃO DE Catharantus roseus POR ENDÓFITOS EXPRESSANDO O GENE gfp
}

\author{
AdALGISA RIBEIRO TORRES
}

Bióloga

Orientador: Prof. Dr. JOÃO LÚCIO DE AZEVEDO

Tese apresentada à Escola Superior de Agricultura "Luiz de Queiroz", Universidade de São Paulo, para obtenção do título de Doutor em Agronomia, Área de Concentração: Genética e Melhoramento de Plantas.

PI R A C I C A B A

Estado de São Paulo - Brasil

Fevereiro - 2005 
Dados Internacionais de Catalogação na Publicação (CIP) DIVISÃO DE BIBLIOTECA E DOCUMENTAÇÃO - ESALQ/USP

Torres, Adalgisa Ribeiro

Diversidade genética de enterobactérias endofíticas de diferentes hospedeiros e colonização de Catharantus roseus por endófitos expressando o gene gfp / Adalgisa Ribeiro Torres. - - Piracicaba, 2005.

$137 \mathrm{p}$.

Tese (Doutorado) - - Escola Superior de Agricultura Luiz de Queiroz, 2005. Bibliografia.

1. Bactéria endofítica 2. Diversidade genética 3. Enterobactéria 4. Marcador molecular 5. Vinca I. Título

CDD 635.98372

"Permitida a cópia total ou parcial deste documento, desde que citada a fonte - O autor" 
Aos meus pais,

Regina Dalva Ribeiro Torres e Itúrbides Fabiano Torres, pela formação e por me apoiarem sempre, mesmo distantes.

DEDICO

Aos meus queridos irmãos Luís Henrique, Heloisa Helena, Virgínia e sobrinhos, Júlia e Breno.

OFEREÇO 


\section{AGRADECIMENTOS}

A Deus, por renovar minhas forças a cada amanhecer...

Ao Prof. Dr. João Lúcio de Azevedo pela orientação, por todo apoio e pelo exemplo.

Ao Dr. Welington Luiz de Araújo pela co-orientação, por todo apoio e valiosas sugestões.

Aos meus familiares, Itúrbides, Regina Dalva, Luís Henrique, Heloisa Helena, Virgínia, Breno, tios e tias, primos e primas pelo carinho, incentivo e apoio durante a execução deste trabalho.

À Profa. Dra. Aline A. Pizzirani-Kleiner pela amizade e agradável convívio durante o desenvolvimento da tese.

À Dra. Mariangela Hungria, pela oportunidade de realização das análises computadorizadas no Laboratório de Biotecnologia do Solo -Embrapa/Soja.

A Fábio Mostasso e Fábio Plotegher, pela cooperação durante as análises computadorizadas.

Ao Rudi E. Procópio, pela disponibilidade do uso de algumas seqüências de enterobactérias de eucalipto.

À amiga Luciana Cursino, pela amizade, inestimável cooperação e incentivo durante a realização deste trabalho.

Ao amigo Fernando Gomes Barcelos pela amizade, incentivo e apoio durante esses anos. 
Às amigas Ana Paula, Denise, Eulália, Juliana, Kerlyng, Luciana Cursino, Patrícia Cardoso, Sula e Taís pela amizade, carinho e apoio.

Aos amigos e colegas do Departamento de Genética Andréa Guelfi, Bira, Clideana, Dieme, Fábia, Farias, Fernando Cardenas, Fredi, Karen, Maria Rita, Marisa, Rodrigo Brogin, Rudimar, Vanderlei dos Santos, pela agradável convivência e companheirismo. Aos amigos e colegas do Laboratório de Genética de Microrganismos: Ágata, Aline Romão, Ana Carolina, Beatriz, Carlos Eduardo, Carolina Quecine, Cláudia, Cristina Maki, Fernanda, Fernando Andreote, Heloize, Joelma, José Antônio, Júlia, Luciana, Manuella, Maria Clara, Mayra, Natalie, Paulo Lacava, Priscilla, Ricardo, Rodrigo Mendes, Rodrigo Stuart, Rudi, Sérgio, Sônia, Taís, Uirá e Vívian, pela amizade, colaboração, apoio, incentivo, valiosas sugestões e agradável convivência.

Aos funcionários do Departamento de Genética da ESALQ/USP, em especial à Léia, Glória e Vitor, pelo apoio administrativo.

Ao Dr. Ricardo Harakava (Instituto Biológico-SP) e Dra. Helaine Carrer (CBTEC/ESALQ/USP), pelos serviços prestados no seqüenciamento das amostras.

Aos colegas do laboratório de Bioquímica de Plantas, coordenado pelo Prof. Dr. Ricardo Azevedo, pela disponibilidade de alguns equipamentos.

A todos os professores e colegas de curso do Departamento de Genética da ESALQ/USP.

À CAPES pela bolsa de doutorado concedida e à FAPESP pelo apoio financeiro. 
"Recordarei os feitos do SENHOR;

recordarei os teus antigos milagres.

Meditarei em todas as tuas obras e considerarei todos os teus feitos."

Salmos 77: 11- 12

"Por tudo o que tens feito,

por tudo o que vais fazer.

Por tuas promessas e tudo o que és,

eu quero te agradecer com todo o meu ser.

Te agradeço, meu SENHOR. "

(CD Diante do Trono) 


\section{SUMÁRIO}

Página

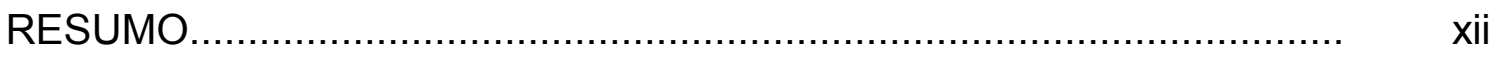

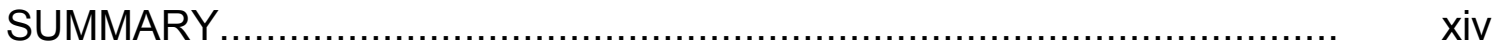

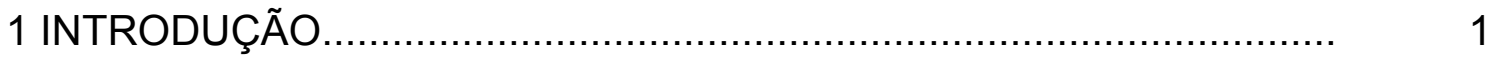

2 REVISÃO DE LITERATURA.........................................................

2.1 Microrganismos endofíticos...................................................

2.1.1 A família Enterobacteriaceae........................................................ 6

2.1.2 Bactérias endofíticas e o controle de patógenos............................ 8

2.1.3 Variabilidade genética em microrganismos endofíticos

e técnicas utilizadas para seu estudo.......................................... 12

2.2 Manipulação genética de microrganismos endofíticos....................... 19

2.2.1 Genes repórteres............................................................. 20

2.2.2 Genes repórteres em vetores de expressão em

bactérias endofíticas

3 IDENTIFICAÇÃO DE ENTEROBACTÉRIAS ENDOFÍTICAS DE

DIFERENTES PLANTAS HOSPEDEIRAS PELO USO DA

ANÁLISE DE RESTRIÇÃO DO DNA RBOSSÔMICO(rDNA)

AMPLIFICADO E POR SEQÜENCIAMENTO DO rDNA........ 26 
Resumo

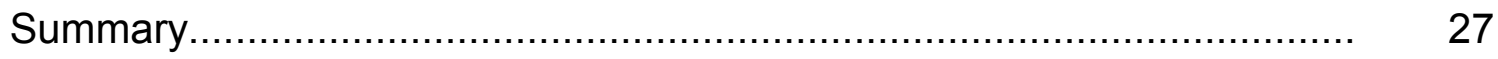

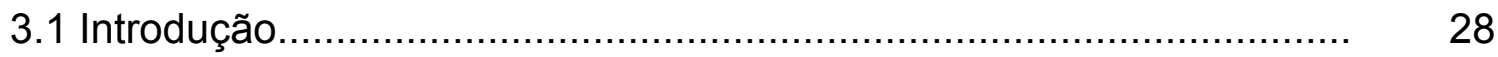

3.2 Material e Métodos............................................................. 30

3.2.1 Seleção de bactérias endofíticas fermentadoras de glicose............ 30

3.2.2 Isolados bacterianos selecionados e condições de cultivo............... 31

3.2.3 Extração de DNA genômico........................................................ 33

3.2.4 Amplificação do rDNA 16S...................................................... 34

3.2.5 Procedimentos de ARDRA ................................................... 35

3.2.6 Seqüenciamento do rDNA 16S e análise das seqüências................ 36

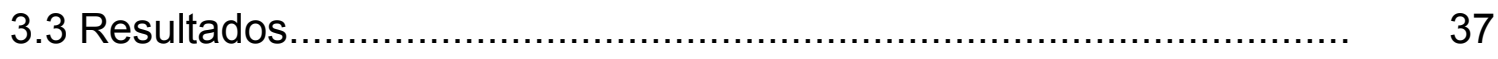

3.3.1 Análise de ARDRA ............................................................. 37

3.3.2 Distribuição e diversidade de isolados de enterobatérias endofíticas.

3.3.3 Seqüenciamento parcial do rDNA $16 \mathrm{~S}$ dos isolados de enterobactérias endofíticas.....................................................

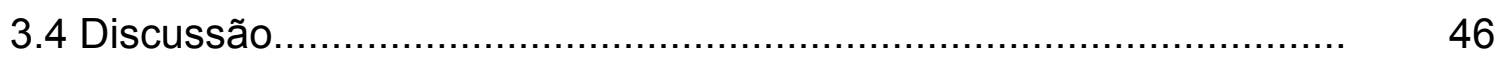

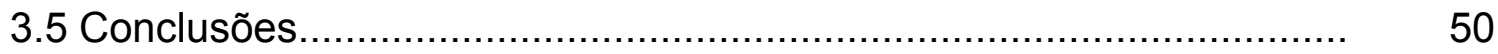


4 DIVERSIDADE DE ENTEROBACTÉRIAS ENDOFÍTICAS DE PLANTA BRASILEIRAS DE GRANDE IMPORTÂNCIA

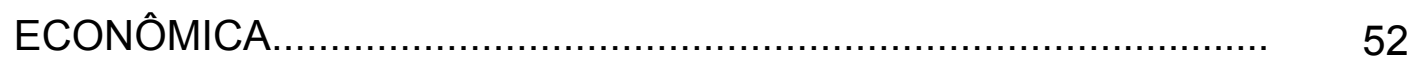

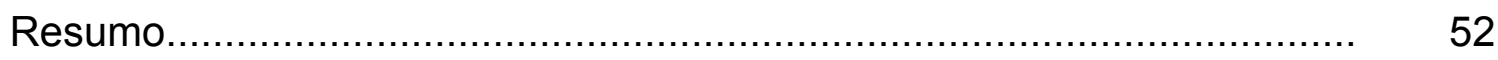

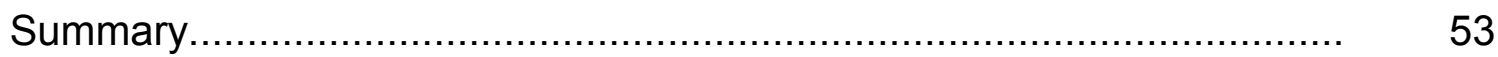

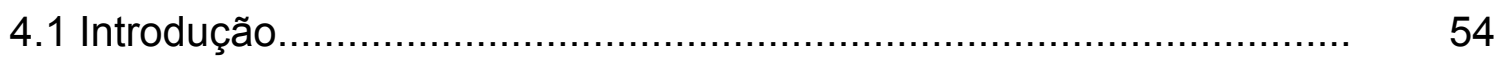

4.2 Material e Métodos.................................................................. 55

4.2.1 Isolados bacterianos e condições de cultivo................................. 55

4.2.2 Teste de sensibilidade a antibiótico.............................................. 56

4.2.3 Teste de produção de endoglicanase.......................................... 56

4.2.4 Extração de DNA genômico........................................................ 58

4.2.5 Análise por BOX-PCR ..................................................... 59

4.2.6 Análise computadorizada de BOX-PCR ...................................... 60

4.2.7 Avaliação do índice de diversidade................................................ 60

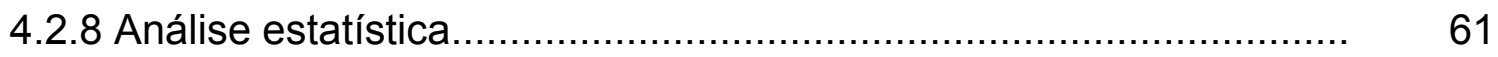

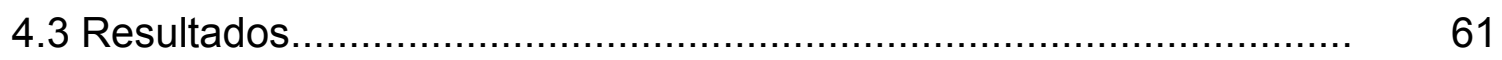

4.3.1 Produção de endoglicanase e sensibilidade a antibiótico................. 61

4.3.2 BOX-PCR de enterobactérias endofíticas..................................... 62

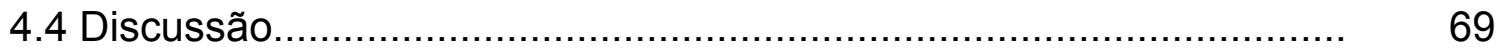

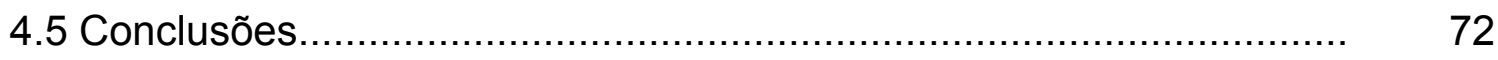


5 COLONIZAÇÃO DE Catharantus roseus (vinca) POR ENTEROBACTÉRIAS ENDOFÍTICAS EXPRESSANDO O GENE gfp.

Resumo

Summary.

5.1 Introdução

5.2 Material e Métodos.

5.2.1 Isolados bacterianos, plasmídio e condições de cultivo.

5.2.2 Extração de DNA genômico.

5.2 .3 Extração de DNA plasmidial........................................... 80

5.2.4 Transformação de enterobactérias endofíticas......................... 80

5.2.5 Teste da estabilidade do plasmídio in vitro.

5.2.6 Detecção da expressão do gene gfp em enterobactérias endofíticas.

5.2.7 Experimentos em casa de vegetação.

5.2.8 Reisolamento de EGMs.

5.2.9 Amplificação do rDNA 16S

5.2.10 Procedimentos de ARDRA.......

5.2.11 Avaliação do índice de diversidade.

5.2.12 Análise estatística 
5.3.1 Transformação de enterobactéria endofítica e estabilidade de

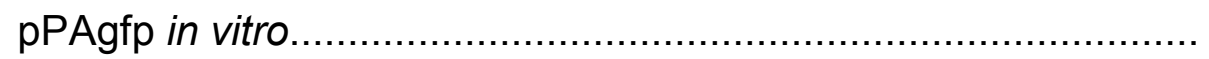

5.3.2 Reisolamento de EGMs.............................................

5.3.3 Efeito da inoculação de EGMs endofíticos sobre a população endofítica natural de vinca................................................

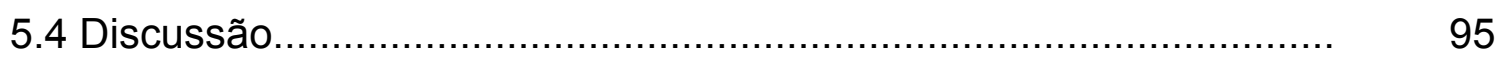

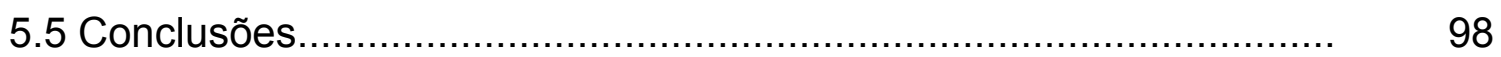

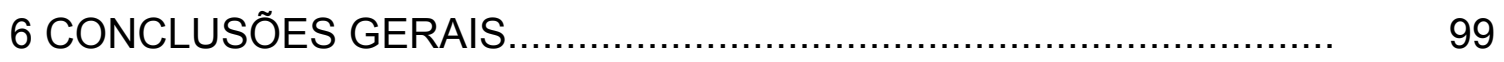

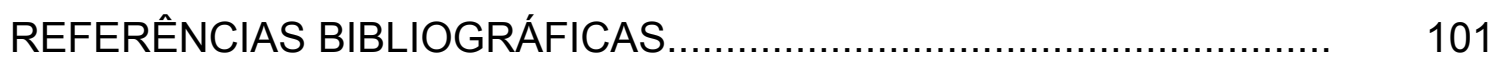




\title{
DIVERSIDADE GENÉTICA DE ENTEROBACTÉRIAS ENDOFÍTICAS DE DIFERENTES HOSPEDEIROS E COLONIZAÇÃO DE Catharantus roseus POR ENDÓFITOS ESPRESSANDO O GENE gfp
}

\author{
Autora: ADALGISA RIBEIRO TORRES \\ Orientador: Prof. Dr. JOÃO LÚCIO DE AZEVEDO
}

\section{RESUMO}

Bactérias endofíticas são aquelas que habitam o interior de tecidos vegetais, sem causar dano aparente aos mesmos, além de desempenhar funções importantes no processo de adaptação das plantas. Especial interesse tem sido dado a tais bactérias devido ao seu potencial no controle biológico. Por isso, é muito importante estudar a diversidade genética de endófitos, além de avaliar o impacto da introdução de endófitos geneticamente modificados no ambiente. Estudos vêm sendo feitos nesse sentido, mas não com bactérias endofíticas da família Enterobacteriaceae. Desta forma, o presente trabalho teve como objetivos estudar a diversidade genética de bactérias endofíticas da família Enterobacteriaceae isoladas de plantas de cacau, cana-de-açúcar, 
citros, eucalipto e soja, utilizando diferentes técnicas moleculares. Análises por ARDRA e seqüenciamento do rDNA 16S identificaram 20 haplótipos e revelaram que os isolados pertenceram aos gêneros Enterobacter, Erwinia e Pantoea, sendo este último o mais freqüente. Tais estudos revelaram ainda que a diversidade dos isolados variou de acordo com a planta hospedeira. A técnica de BOX-PCR foi também utilizada para avaliar a diversidade dos isolados. Um total de 23 diferentes OTUs (operational taxonimic units) obtidas indicaram que o total de isolados avaliados compreenderam pelo menos 23 espécies diferentes. Dois isolados foram transformados com pPAgfp, um plasmídio contendo os genes de resistência ao antibiótico ampicilina e o gene gfp, que codifica a proteína verde fluorescente. Tais isolados foram inoculados em plântulas de Catharantus roseus (vinca) e foi feito reisolamento de bactérias endofíticas em dois períodos diferentes após a inoculação. O impacto desta inoculação na diversidade da comunidade microbiana natural de vinca foi avaliado utilizando-se a técnica de ARDRA, a qual mostrou que os endófitos expressando gfp colonizaram as raízes e caules das plantas inoculadas, sem causar qualquer sintoma de doença. Além disso, os colonizadores endofíticos não levaram à diminuição da diversidade da população microbiana natural de vinca. Os resultados obtidos poderão contribuir para a compreensão sobre a interação entre Enterobacteriaceae endofítica e planta hospedeira, além de ajudar a responder questões sobre o papel ecológico dos endofíticos e seu potencial biotecnológico. 


\title{
GENETIC DIVERSITY OF ENDOPHYTIC ENTEROBACTERIA FROM DIFFERENT HOSTS AND COLONIZATION OF Catharantus roseus BY ENDOPHYTES EXPRESSING gfp GENE
}

\author{
Author: ADALGISA RIBEIRO TORRES \\ Adviser: Prof. Dr. JOÃO LÚCIO DE AZEVEDO
}

\section{SUMMARY}

Endophytic bacteria have been defined as those that reside within living plant tissues, or extracted from inner plant parts without causing apparent damage to them. They also are able to play an important role in the process of plant adaptation. There is an increasing interest to endophytic bacteria and its potential in the biological control and many studies has been done in order to evaluate the diversity and the impact of endophytes and genetically modified endophytes (GME) released into environment. In this way, information about the diversity of endophytic bacteria has been obtained, except for bacteria exclusively from Enterobacteriaceae family belonged to different host plants. Thus, the aim of the present work was study the diversity of Enterobacteriaceae bacteria isolated from citrus, cocoa, eucalypti, soybean and sugar cane by different molecular approaches. The $16 \mathrm{~S}$ rDNA of each 
isolate was amplified by PCR and the isolates were grouped into 20 clusters by analysis of restriction patterns of the PCR-amplified 16S rDNA (ARDRA). These analysis showed a variety of organisms, with 5 different genera encountered: Pantoea was most frequently encountered followed by Enterobacter and Erwinia, which isolates presented the great bacterial diversity according to host plants. Through cluster analysis of the BOX-PCR technique profiles, 23 different OTUs (Operational Taxonomic Units) were distinguished, the presence of 23 OTUs could indicate that isolates comprised at least 23 different species. Two isolates were transformed with pPAgfp, a plasmid harboring the ampicillim resistance gene and the gfp gene, which encodes for the green fluorescent protein. These two isolates were inoculated in seedlings of Catharantus roseus (vinca) and re-isolation of endophytic was performed in two times after inoculation. The impact of endophytes inoculation was evaluated by using the ARDRA technique. It showed that endophytes expressing gfp colonized roots and shoots of inoculated plants without causing any symptom of disease. Besides, the endophytes colonizers do not decreased the diversity of the vinca's natural microbiota. The results obtained here provided important insights into the endophytic Enterobacteriaceae-host relationship that will be useful for further answer basic questions about the ecological role of the endophytes and its biotechnological potential. 


\section{INTRODUÇÃO}

Bactérias endofíticas são aquelas que habitam o interior de tecidos de plantas sem causar dano aparente às mesmas (Azevedo et al., 2000). Tais bactérias promovem o crescimento vegetal, conferem ao seu hospedeiro resistência ao estresse e a alterações fisiológicas, além de os protegerem contra herbivoria e organismos patogênicos (Neto et al., 2004). As bactérias endofíticas ocupam o mesmo ambiente de muitos fitopatógenos, favorecendo seu uso como agentes no controle biológico de patógenos (Hallmann et al., 1997). Tais bactérias podem também ser modificadas geneticamente e reintroduzidas no hospedeiro, conferindo características desejáveis ao mesmo (Andreote et al., 2004). Além disso, a manipulação genética de bactérias endofíticas é muito mais fácil que a manipulação de plantas (Newman \& Reynolds, 2005). Para tanto, é importante conhecer a diversidade genética das bactérias endofíticas, não somente para compreender seu papel na interação com a planta hospedeira, como também para sua aplicação biotecnológica (di Cello et al., 1997). Inúmeras técnicas têm sido utilizadas para avaliar diversidade genética, dentre as quais destacam-se a análise de restrição do rDNA 16S amplificado (ARDRA), seqüenciamento do rDNA 16S e fingerprinting 
do DNA genômico por BOX-PCR (Schloter et al., 2000). A compreensão desta diversidade genética pode representar a base para a utilização de endófitos geneticamente modificados (EGMs) como ferramenta biotecnológica, uma vez que seu sucesso depende de sua capacidade de competir com a microbiota natural e colonizar a planta (Germaine et al., 2004). Nesse contexto, é de suma importância avaliar o impacto da introdução destes EGMs no ambiente (Andreote et al, 2004). Algumas ferramentas têm sido utilizadas com êxito para monitorar tais organismos no ambiente, entre as quais a marcação de bactérias com o gene gfp, que codifica uma proteína verde fluorescente facilmente detectável (Li et al., 1999; Germaine et al., 2004). Vários estudos descrevem a análise da diversidade genética de bactérias endofíticas (Araújo et al., 2000; Araújo et al., 2001; Araújo et al., 2002; Boddey et al., 2003; Conn \& Franco, 2004; Estrada, 2002; Fisher \& Petrini, 1992; Jiménes et al., 2003; KuklinskySobral et al., 2004; Procópio, 2004), mas nenhum deles abordou a relação entre diversos hospedeiros vegetais e bactérias endofíticas pertencentes à família Enterobacteriaceae. Diante do exposto, o presente trabalho teve como objetivos (i) selecionar amostras de bactérias cultiváveis pertencentes à família Enterobacteriaceae, obtidas de plantas de cacau, cana-de-açúcar, citros, eucalipto e soja; (ii) amplificar por PCR o rDNA $16 \mathrm{~S}$ de cada isolado; (iii) agrupar os isolados em haplótipos pela análise dos padrões de restrição obtidos após a digestão do rDNA 16S amplificado; (iv) identificar e caracterizar os isolados pertencentes aos principais haplótipos de ARDRA pela seqüência do 
rDNA 16S; (v) avaliar a produção de celulase e a sensibilidade destas bactérias aos antibióticos ampicilina e canamicina; (vi) analisar a diversidade destes endófitos pela técnica de fingerprinting do DNA genômico por BOX-PCR; (vii) transformar dois isolados de enterobactérias endofíticas com o plasmídio pPAgfp; (viii) avaliar a estabilidade in vitro de pPAgfp nestes EGMs; (ix) inocular enterobactérias endofíticas do tipo selvagem e respectivos EGMs em plântulas de Catharantus roseus (vinca); (x) reisolar estes EGMs e analisar o impacto dos mesmos sobre a população natural de vinca, usando a técnica de. ARDR. 


\section{REVISÃO DE LITERATURA}

\subsection{Microrganismos endofíticos}

Microrganismos endofíticos, ou endófitos, uma palavra derivado do grego endon-dentro e phyton-planta, tem causado controvérsia desde a sua criação em 1866 por De Bary (Baldani et al., 2002; Saikkonen et al., 2004). Contudo, nos últimos 10 anos, este termo vem sendo bem aceito pela literatura (Wilson, 1995, Saikkonen et al., 2004). Assim, o conceito mais recente e corrente é de que os microrganismos endofíticos são aqueles que habitam o interior dos tecidos vegetais da planta hospedeira sem causar danos à mesma, nem tampouco formam estruturas externas visíveis (Azevedo, et al.,2000).

Microrganismos endofíticos vêm sendo isolados de uma extensa variedade de plantas, incluindo muitas de interesse econômico, como algodão (Quadt-Hallmann, et al., 1997a); arroz (Stolzfus et al., 1997), banana (Pereira et al., 1999), batata, (Long et al., 2003; Berg et al., 2005), cacau (Lana, 2004; Rubini et al., 2005), cana-de-açúcar (Döbereiner, 1992, Oliveira et al., 2002, Boddey et al., 2003), cenoura (Surette et al., 2003), citros (Araújo et al, 2001, Araújo et al., 2002, Marcon, 2002), ervilha (Elvira-Recuenco \& Van Vuurde, 
2000); inhame (Tor et al., 1992), leguminosa Stylosanthes (Pereira et al., 1993); milho (Araújo et al., 2000; Estrada et al., 2002), soja (Kuklinsky-Sobral et al., 2004) tomate (Pillay \& Nowak, 1997), trigo e sorgo (Zinniel et al., 2002) e videira (Bell et al., 1995). A existência de endófitos em plantas medicinais tem sido constatada em inúmeras espécies, estando muitas vezes envolvidos em complexas relações de síntese, acúmulo e degradação de metabólitos secundários de interesse econômico (Neto et al., 2004).

A origem, forma de penetração, colonização e transmissão de bactérias endofíticas são muito discutidas. Elas podem ser provenientes de sementes, da rizosfera, do filoplano e de material propagado vegetativamente (Mclnroy \& Kloepper, 1995; Hallmann et al., 1997; Reinhold-Hurek \& Hurek, 1998). Sua penetração pode ocorrer pelos estômatos, ferimentos, áreas de emergências laterais das raízes, e podem produzir enzimas hidrolíticas capazes de degradar a parede celular dos vegetais, sendo este um possível mecanismo de penetração (Quadt-Hallmann et al., 1997a; Shishido et al., 1999, McCully, 2001).

O fato dessas bactérias serem capazes de colonizar os tecidos internos das plantas confere vantagens sobre outros microrganismos, pois podem sobreviver em um ambiente mais uniforme, além de serem menos afetadas pela temperatura, potencial osmótico e radiação ultravioleta (Lodewyckx et al., 2002). As bactérias endofíticas podem conferir ao seu hospedeiro características como maior resistência a condições de estresse, alterações nas 
condições fisiológicas, suprimento de nitrogênio, produção de reguladores de crescimento vegetal e outros componentes de interesse biotecnológico (como enzimas e drogas de interesse farmacêutico). Além disso, há relatos de bactérias endofíticas capazes de degradar poluentes em ambientes contaminados (Newman \& Reynolds, 2005). Já que bactérias endofíticas ocupam nicho ecológico semelhante ao de fitopatógenos, elas também apresentam grande potencial para o controle biológico destes patógenos (Hallmann et al., 1997; Kunoh, 2002; Coombs et al., 2004).

\subsubsection{A família Enterobacteriaceae}

A família Enterobacteriacea, do domínio Gamma - Proteobacteria, consiste de um grande grupo que engloba bactérias Gram-negativa geralmente associadas a infecções intestinais, mas podem ser encontradas em quase todos os ambientes naturais. Tal família engloba espécies intimamente relacionadas (Hoffmann \& Roggenkamp, 2003), pertencentes a vários gêneros: Arizona, Citrobacter, Edwardsiella, Enterobacter, Erwinia, Hafnia, Klebsiella, Morganella, Pantoea, Proteus, Providencia, Salmonella, Serratia, Shigella, Yersinia, Escherichia, no qual E. coli é a espécie mais estudada (Bergey, et al., 1994).

Vários gêneros da família Enterobacteriaceae selecionados a partir de solo incluem bactérias diazotróficas (capazes de fixar nitrogênio atmosférico), 
particularmente aquelas da rizosfera de arroz. Estas enterobactérias diazotróficas incluem os gêneros Klebsiella, Enterobacter, Citrobacter e provavelmente vários outros ainda não identificados (Kennedy et al., 2004).

Enterobactérias, particularmente Klebsiella, são comumente endófitos de plantas. A colonização endofítica por Klebsiella pode ser benéfica, uma vez que bactérias deste gênero são capazes de fornecer nitrogênio fixado ou hormônios de crescimento para a planta hospedeira (Dong et al., 2003). Recentemente, foi demonstrado que K. pneumoniae fixa nitrogênio em trigo (Iniguez et al., 2004) e em variedades de batata doce africanas (Reiter et al., 2003).

Os gêneros Pantoea e Enterobacter também têm sido mencionados como bactérias diazotróficas. Asis \& Adachi (2004) relataram o isolamento de $P$. agglomerans e E. asburiae diazotróficas endofíticas de batata doce. Araújo et al. (2001) isolaram inúmeras bactérias endofíticas de porta-enxertos de citros, dentre as quais predominou a espécie $P$. agglomerans; e E. cloacae foi isolado da maioria das plantas. Da mesma forma, Lacava et al. (2004) também isolaram P. agglomerans e E. cloacae endofíticas de citros. Kuklinsky-Sobral et al. (2004) isolaram Pantoea sp., assim como E. agglomerans e E. sakasakii endofíticas de soja no Brasil. Procópio (2004) isolou P. agglomerans, P. ananas, P. stewartii, assim como E. agglomerans, E. pyrinus endofíticos de variedades de eucalipto cultivadas no Brasil.

Outro gênero de enterobactéria encontrado como endófito é Erwinia. Convém ressaltar que a espécie $E$. amylovora é patogênica, causadora da 
podridão mole em batata, maçã e pêra, tendo nestas últimas culturas um impacto econômico significativo (Burse et al., 2004). Foi relatado recentemente o isolamento de $E$. carotovora e E. chrysanthemi endofítica de variedades de eucalipto (Procópio, 2004), bem como o isolamento de Erwinia sp. de plantas de soja (Kuklinsky-Sobral et al., 2004).

\subsubsection{Bactérias endofíticas e o controle de patógenos}

Com o acúmulo de informações a respeito da interação planta/endófitos e os resultados promissores observados, tem sido verificada uma atenção especial ao estudo de bactérias endofíticas como promotoras de crescimento vegetal (Hallmann et al., 1997; Bent \& Chanway, 1998) e como agentes de controle biológico de doenças (Hallmann et al., 1997; M'Piga et al., 1997).

As bactérias endofíticas, da mesma forma que fitopatógenos, apresentam a capacidade de penetrar na planta e se disseminar de forma sistêmica no hospedeiro, habitando de forma ativa o apoplasto (Mahaffee et al., 1997; Quadt-Hallmann et al., 1997b), vasos condutores (Mahaffee et al., 1997; Hallmann et al., 1997) e, ocasionalmente, pode haver colonização intracelular (Quadt-Hallmann \& Kloepper, 1996; Quadt-Hallmann et al., 1997a).

Bactérias endofíticas colonizam um nicho ecológico semelhante àquele ocupado por fitopatógenos, favorecendo-as como agentes de controle biológico 
de doenças (Hallmann et al., 1997, Kunoh, 2002; Coombs et al., 2004). Este controle biológico pode ocorrer principalmente devido à atuação direta sobre o patógeno no interior da planta hospedeira (Pan et al., 1997), por produção de compostos antimicrobianos (Pleban et al., 1997; Marcon, 2002; Kunoh, 2002; Taechowisan et al., 2003), indução de resistência sistêmica (Krishnamurthy \& Gnanamanickam, 1997; Lodewyckx et al., 2002), competição por nutrientes (Mari et al., 1996) ou produzindo enzimas (quitinases ou celulases) que degradam a parede celular de fungos patogênicos (Pleban et al., 1997; Downing \& Thomson, 2000; El-Tarabily, 2003).

O controle biológico de doenças e pragas de culturas de interesse, utilizando bactérias endofíticas, pode ser realizado de forma indireta. Neste caso, o endófito não atua diretamente sobre o patógeno, mas induz uma resposta na planta, ativando a resistência ao patógeno. O principal componente bacteriano sugerido como indutor deste processo é um lipopolissacarídeo (LPS), presente na parede celular de bactérias Gram-negativa. Além do LPS, outras moléculas como sideróforos e ácido salicílico produzidas por bactérias são também consideradas candidatas (van Loon et al., 1998). Em plantas de tabaco foi demonstrado que LPS da bactéria endofítica Burkholderia cepacia estimulou resposta sistêmica ao ataque do patógeno Phytophthora nicotianae (Coventry \& Dobery, 2001).

Estudos têm mostrado que a aplicação de rizobactérias (as quais também colonizam endofiticamente o hospedeiro) em sementes ou na raiz pode 
induzir resistência a múltiplos patógenos dos tecidos foliares como vírus, fungos e bactérias (Kloepper et al., 1999). Em outro caso, foram utilizadas rizobactérias, em combinação ou em aplicações simples de cada bactéria, e verificou-se que estas bactérias, além de promover o crescimento vegetal, induziram a resistência sistêmica do hospedeiro às bactérias Pseudomonas syringae pv. lachrymans, Enwinia tracheiphila e ao fungo Colletotrichum orbiculare (Raupach \& Kloepper, 1998). Em tomate, a aplicação da rizobactéria promotora de crescimento Pseudomonas sp. (linhagem PsJN) induziu resistência sistêmica a Verticilium dahliae. Os resultados deste estudo mostraram que a colonização endofítica da planta pela rizobactéria foi necessária para a indução de resposta contra o patógeno (Sharma \& Nowak, 1998).

Os fatores que levam à indução de resistência sistêmica contra patógenos ainda não estão bem estabelecidos. Sabe-se que ela está associada a alterações bioquímicas e estruturais na planta hospedeira, as quais afetam adversamente o crescimento e desenvolvimento do patógeno (Duijff et al., 1997; M'piga et al., 1997; Sharma \& Nowak, 1998). A penetração ativa de Pseudomonas sp. (linhagem PsJN), com hidrólise de celulose sugere que alguns endófitos podem causar reação de hipersensibilidade, ativando a resistência sistêmica contra patógenos (Quadt-Hallmann et al., 1997a). Tem sido observado que esta resistência induzida em tomate está relacionada à colonização dos tecidos internos do hospedeiro e à presença de um 
lipopolissacarídeo da membrana externa (Cadeia O-antigênica) da bactéria endofítica (Duijff et al., 1997).

A comunidade endofítica é muito dinâmica, havendo interações entre as espécies bacterianas e entre estas com o hospedeiro. Araújo et al. (2001) isolaram inúmeras bactérias endofíticas de porta-enxertos de citros, entre elas Alcaligenes sp, Bacillus megaterium, B. pumilus, B. subtilis, B. cepacia e $P$. agglomerans. Foram realizados testes in vitro de interação entre tais bactérias e Guignardia citricarpa, a qual pode influenciar a composição da população endofítica nas folhas deste hospedeiro. Neste estudo foi verificado que o fungo G. citricarpa, isolado endofiticamente de folhas, inibiu inúmeras bactérias do gênero Bacillus, e estimulou o crescimento de Erwinia herbicola (sin. P. agglomerans) (Araújo et al., 2001; Azevedo et al., 2000). De acordo com os autores, este resultado aliado à alta similaridade por marcadores de RAPD, mostrou que E. herbicola deve ser um endófito plenamente adaptado ao hospedeiro e a outros endófitos como G. citricarpa, enquanto que B. pumilus e B. subtilis devem ser bactérias epifíticas que eventualmente, na ausência de competição com G. citricarpa, colonizam a planta endofiticamente.

A utilização prática destas bactérias endofíticas no controle biológico de patógenos depende de inúmeros fatores relacionados à interação patógenos bactérias endofíticas - planta, pois a competição existente entre os microrganismos neste habitat pode reduzir a eficiência do controle, inviabilizando a sua utilização. Segundo Raupach \& Kloepper (1998), na maioria 
dos casos, o controle biológico que ocorre naturalmente é devido a uma mistura de microrganismos antagônicos sendo portanto, muito importante avaliar a interação de diferentes bactérias para o controle de patógenos.

\subsubsection{Variabilidade genética em microrganismos endofíticos e técnicas utilizadas para seu estudo}

Os microrganismos existem há aproximadamente 4 bilhões de anos e muito pouco deles (menos de $5 \%$ ) é conhecido, mesmo com o emprego das técnicas modernas da biologia molecular As suas funções são menos conhecidas ainda (Melo et al., 2002). Em virtude da sua longa história evolutiva e da necessidade de adaptação aos mais distintos ambientes, os microrganismos acumularam uma impressionante variabilidade genética, tão vasta quanto desconhecida.

Os estudos da variabilidade genética em microrganismos endofíticos, ao contrário daqueles em fitopatogênicos, são ainda escassos. Estes estudos são de fundamental importância para o entendimento da interação endófito-planta e no desenvolvimento de uma agricultura sustentável baseada no controle biológico de pragas e doenças. Neste aspecto, muitas questões ainda estão em aberto em relação à especificidade das diferentes interações e das relações existentes entre endófito-patógenos-planta e o meio-ambiente (Azevedo et al., 2000). Em termos aplicados, um dos aspectos mais importantes do estudo da 
variabilidade genética diz respeito à identificação de agentes patogênicos que ora são confundidos com endófitos e vice-versa. Outro ponto é o desenvolvimento de candidatos ao controle de doenças e pragas com a identificação de grupos ou genótipos específicos, conferindo resistência às plantas. A relação específica de um genótipo ou grupo de genótipos de um determinado endófito com um hospedeiro, uma condição ambiental, um tecido ou tecidos específicos, época do ano ou estado fisiológico também são aspectos importantes que podem ser elucidados com os estudos de variabilidade genética (Azevedo et al., 2002).

Para tanto, têm-se desenvolvido ao longo dos anos ferramentas técnicas que podem ser utilizadas nos estudos da variabilidade genética em endófitos. Algumas utilizam o número e o tamanho de plasmídios e de cromossomos ou comparam a produção de proteínas ou enzimas específicas (isoenzimas) para diferenciar indivíduos e populações. Dentre as mais modernas, estão aquelas envolvendo diretamente o DNA (Azevedo et al., 2002).

A aplicação de técnicas baseadas em ácidos nucléicos tem auxiliado muitos estudos de variabilidade genética microbiana, por não depender do estado fisiológico do microrganismo, sendo possível estudar microrganismos não cultiváveis. As técnicas mais utilizadas para estes estudos estão listadas na Tabela 1.

Uma metodologia muito aplicada no estudo da diversidade microbiana é a técnica de RAPD, que utiliza iniciadores curtos e de seqüência aleatória que 
se anelam a diferentes locais no DNA genômico, gerando por reação em cadeia pela polimerase -PCR, produtos de diferentes tamanhos que podem ser separados por eletroforese em gel de agarose. Williams et al., (1990) e Welsh \& McClelland (1990) descreveram esta classe de marcadores moleculares, que tem sido extremamente útil para estudos de filogenia e caracterização de indivíduos (Louws et al., 1999); estudo da comunidade microbiana de ambientes aquáticos (Franklin et al., 1999, Hazem \& Manar, 2003); bactérias e fungos associados a plantas (Araújo et al., 2001, Latha et al., 2004; Tigano et al., 2003) e a insetos (Rivera \& Priest, 2003; Dalzoto et al., 2003). Dentre as várias técnicas citadas, os genes rDNA ribossomais têm sido muito utilizados por estarem presentes em todos os organismos, derivarem de um ancestral comum, além de serem geneticamente estáveis e apresentarem um tamanho suficiente para análises filogenéticas. Além disso, as seqüências de rDNA são extremamente conservadas entre todos os organismos que compartilham aquela espécie de rRNA, e possuem algumas regiões variáveis, 
Tabela 1. Abreviações e significado das técnicas de biologia molecular (Schloter et al., 2000)

\begin{tabular}{|c|c|c|}
\hline Abreviações & Significado & Referência \\
\hline AFLP & $\begin{array}{l}\text { Polimorfismo de tamanho de fragmento de } \\
\text { amplificado }\end{array}$ & $\begin{array}{l}\text { Vandamme et al., 1996; } \\
\text { Vaneechoutte, } 1996\end{array}$ \\
\hline AP-PCR & Reação em cadeia da polimerase com primers arbitrários & Vaneechoutte, 1996 \\
\hline ARDRA & Análise de restrição do DNA ribossômico amplificado & Vaneechoutte, 1996 \\
\hline BOX-PCR & $\begin{array}{l}\text { Reação em cadeia da polimerase de seqüências de DNA } \\
\text { entre os elementos BOX }\end{array}$ & $\begin{array}{l}\text { Louws et al., 1996; } \\
\text { Rademaker et al., } 1998\end{array}$ \\
\hline DGGE & Eletroforese em gel gradiente desnaturante & Muyzer, 1999 \\
\hline ERIC-PCR & $\begin{array}{l}\text { Reação em cadeia da polimerase de seqüências de DNA } \\
\text { entre seqüências intergênicas consensuais repetitivas de } \\
\text { enterobactérias }\end{array}$ & $\begin{array}{l}\text { Louws et al., 1996; } \\
\text { Rademaker et al., } 1998\end{array}$ \\
\hline FAME & Análise de metil éster ácidos graxos & Vandamme et al., 1996 \\
\hline IGS & $\begin{array}{l}\text { Análise de espaçadores intergênicos (=ITS e =RISA } \\
\text { quando usado com espaçadores ribossômicos) }\end{array}$ & Gürtler et al., 1996 \\
\hline Inter-LINE-PCR & $\begin{array}{l}\text { Reação em cadeia da polimerase de seqüências de DNA } \\
\text { entre elementos longos dispersos no genoma }\end{array}$ & Smida et al., 1996 \\
\hline ITS & Análise de espaçadores internos transcritos (=RISA) & Gürtler et al., 1996 \\
\hline MLEE & Eletroforese de enzimas usando múltiplos loci & Selander et al., 1986 \\
\hline PFG E & Eletroforese em gel de campo pulsado & $\begin{array}{l}\text { Vandamme et al., 1996; } \\
\text { Vaneechoutte, } 1996\end{array}$ \\
\hline PCR-RFLP & $\begin{array}{l}\text { Polimorfismo de tamanho de fragmento de restrição de } \\
\text { DNA gerado por reação em cadeia da polimerase }\end{array}$ & $\begin{array}{l}\text { Vandamme et al., 1996; } \\
\text { Vaneechoutte, } 1996\end{array}$ \\
\hline RAPD-PCR & $\begin{array}{l}\text { Amplificação aleatória de DNA polimórfico por reação em } \\
\text { cadeia da polimerase }\end{array}$ & Vaneechoutte, 1996 \\
\hline RC-PFGE & $\begin{array}{l}\text { Eletroforese em gel de campo pulsado do DNA digerido } \\
\text { por endonucleases de corte raro }\end{array}$ & Vaneechoutte, 1996 \\
\hline REP-PCR & $\begin{array}{l}\text { Reação em cadeia da polimerase de seqüências } \\
\text { palindrômicas extragênicas repetitivas }\end{array}$ & $\begin{array}{l}\text { Louws et al., 1996; } \\
\text { Rademaker et al., } 1998\end{array}$ \\
\hline rep-PCR & $\begin{array}{l}\text { Reação em cadeia da polimerase de seqüências } \\
\text { palindrômicas extragênicas repetitivas de elementos do } \\
\text { tipo REP, ERIC ou BOX }\end{array}$ & $\begin{array}{l}\text { Louws et al., 1996; } \\
\text { Rademaker et al., } 1998\end{array}$ \\
\hline RISA & Análise de espaçadores intergênicos ribossômicos & Gürtler et al., 1996 \\
\hline SCAR & Amplificação de seqüências caracterizadas do DNA & $\begin{array}{l}\text { Paran \& Michelmore, } \\
1993\end{array}$ \\
\hline TGGE & Eletroforese em gel gradiente de temperatura & Muyzer, 1999. \\
\hline
\end{tabular}


sendo que o grau de variação nessas regiões especificas pode variar de um táxon a outro (Procópio, 2004).

Outra técnica aplicada ao estudo da diversidade microbiana é o ARDRA, que consiste na amplificação e posterior digestão do rDNA com enzimas de restrição. Este método é baseado no princípio de que os sítios de restrição no rDNA são conservados de acordo com padrões filogenéticos. Desta forma, pode ser utilizado o rDNA $16 \mathrm{~S}$ para o estudo de grupos heterogêneos, ou a região espaçadora entre o $16 \mathrm{~S}$ e o 23S rDNA para o estudo de grupos muito similares (Heyndrickx et al., 1996; Van Elsas et al., 1998; Ranjard et al., 2000). Esta técnica tem sido aplicada para o estudo da diversidade microbiana associada a vegetais ou a diferentes solos (Ovreas \& Torsvik, 1998; KuklinskySobral et al., 2004; Mocali et al., 2003; Chelius \& Triplett, 2001; Aquilante et al., 2004); análise da diversidade genética de bactérias degradadoras de pesticidas (Desaint et al., 2000); caracterização de bactérias diazotróficas (Cruz et al., 2001) entre outras. A análise do ARDRA pode identificar linhagens em nível de gênero ou espécie, sendo dessa forma muito usado para estudo taxonômico e filogenético (Ventura et al., 2001; Fromin et al., 2001; Rodas et al., 2003). Além disso, o ARDRA é mais rápido do que o seqüenciamento do $16 S$ rDNA e menos oneroso. A maioria das caracterizações é realizada usando um pequeno número de enzimas, amplamente utilizadas e uma interpretação visual do padrão de restrição (Heyndryckx et al., 1996). 
O ARDRA também pode ser utilizado para análise filogenética de organismos relacionados, sendo este caso, mais laborioso e complexo, por necessitar de um número maior de enzimas de restrição combinadas, para gerar polimorfismo que serão analisados em programas de computador (Koeleman et al., 1998; Fromin et al., 2001).

Análise de genes rDNA $16 S$ ou $23 S$ por seqüenciamento ou por ARDRA é uma ferramenta que vem sendo muito utilizada para o estudo de diversidade filogenética e taxonômica de isolados bacterianos. O poder de resolução de tais técnicas baseadas no rDNA é valioso para identificar bactérias em nível de reino ou gênero, mas não de espécie ou subespécie (Stackebrandt \& Goebel, 1994; Hauben et al., 1999). Por isso, foram propostos métodos rápidos de fingerprinting genômico de alta resolução para classificar bactérias em nível de espécies, subespécies ou linhagem. Dentre estes métodos destaca-se o repPCR, também conhecido por fingerprinting genômico, uma técnica descrita por Rademaker \& Bruijn em 1997, que consiste na amplificação de seqüências repetitivas altamente conservadas no genoma. Rep-PCR inclui BOX-PCR (utiliza primers que se anelam a seqüências de DNA altamente repetitivas e conservadas), ERIC-PCR (utiliza primers que se anelam a seqüências intergênicas consensuais altamente repetitivas de enterobactérias) e REP-PCR (utiliza primers que se anelam a seqüências palindrômicas extragênicas repetitivas). 
BOX-PCR reúne várias vantagens, uma vez que é uma técnica rápida, de execução fácil e altamente discriminatória para espécies, produzindo resultados que representam bem as análises baseadas na homologia DNA-DNA (Figura 1). Esta técnica vem sendo muito utilizada para avaliar diversidade genética de populações microbianas. BOX-PCR foi utilizada por Rademaker et al. (2000) para estudar diversidade genética em população de Xanthomonas. Vanbroekhoven et al. (2004) utilizaram tal técnica para classificar linhagens clonais de Sphingomonas, um organismo que participa da degradação de contaminantes orgânicos em solo e outros ambientes. Goris et al., 2003 utilizaram BOX-PCR para avaliar diversidade genética entre linhagens bacterianas que receberam o gene gfp. BOX-PCR também foi utilizado por Yang et al. (2004) para avaliar a diversidade genética em linhagens de E. coli isolada de ração bovina.

Muitas destas técnicas utilizam definições de agrupamento taxonômico que são a princípio, arbitrárias. No entanto, tem se desenvolvido uma nova forma que hoje é pré-requisito nos estudos de diversidade microbiana chamada operational taxonomic units (OTUs). Tal definição é clara, assim como cientificamente possível de validar universalmente os grupos taxonômicos. De acordo com Yang et al. (2004), quando a diversidade microbiana é inferida a partir de fingerprints moleculares ou de informações baseadas em seqüências, as OTUs individuais devem ser definidas como espécies em potencial. 


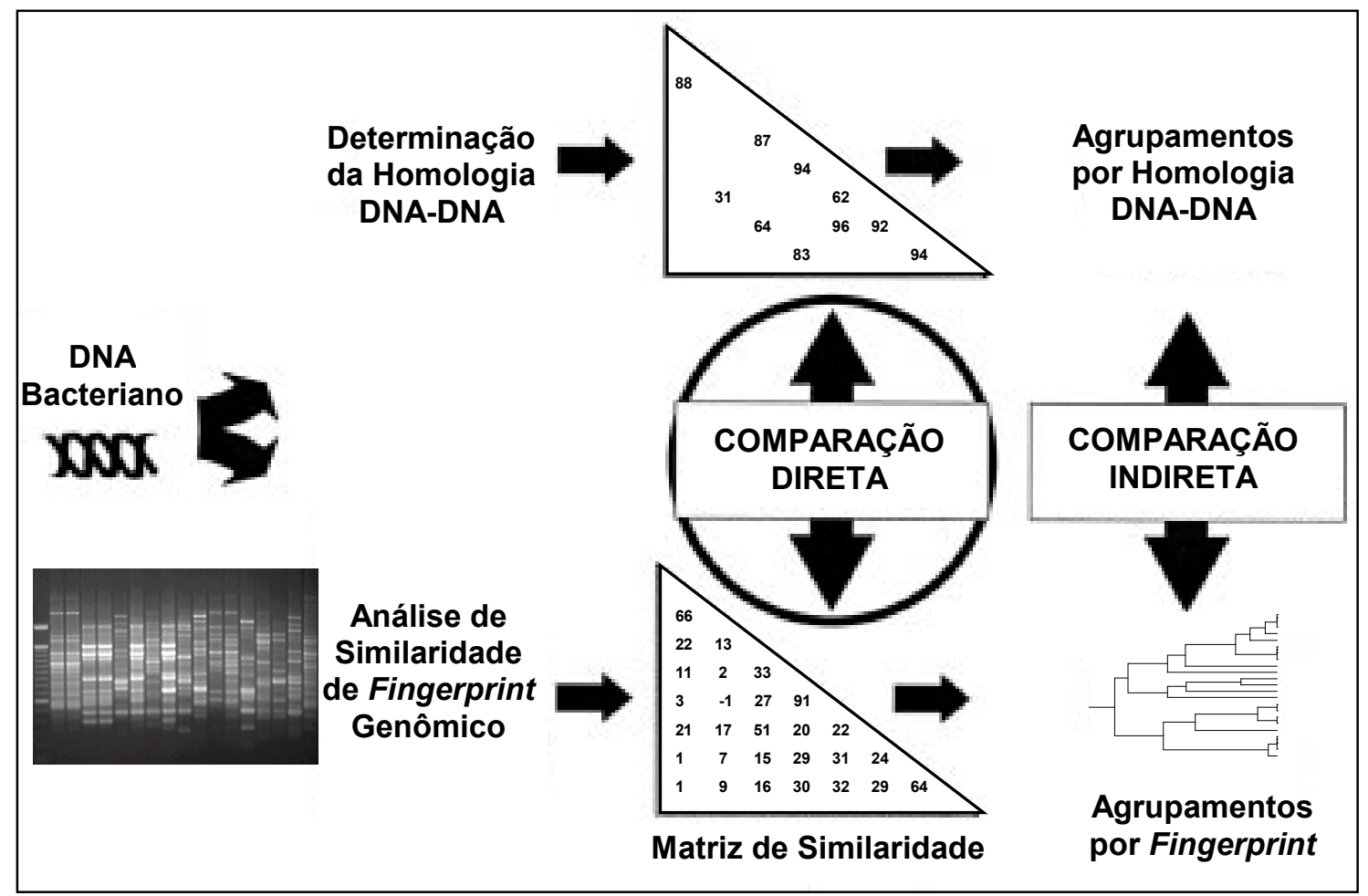

Figura 1 - Esquema ilustrativo da comparação direta e indireta entre as análises de fingerprinting genômico e estudos de homologia DNA - DNA (modificado de Schloter et al., 2000)

\subsection{Manipulação genética de microrganismos endofíticos}

O estudo e uso de microrganismos endofíticos no controle biológico é extremamente promissor, e o aumento das pesquisas a respeito do assunto pode facilitar o entendimento de interações, permitindo a utilização conjunta dos conhecimentos gerados e da tecnologia do DNA recombinante. 


\subsubsection{Genes repórteres}

Os genes repórteres são genes que codificam uma proteína, geralmente de atividade enzimática, cujo produto é facilmente detectável. São úteis na avaliação in situ de atividades de transcrição de promotores em células bacterianas, contudo estes têm sido amplamente utilizados em fungos, nematóides e plantas (Valadares-Inglis et al., 2002).

Os principais genes repórteres utilizados em microrganismos endofíticos são os genes lacZ, gus $A$ e gfp. O gene LacZ codifica a enzima bacteriana $\beta$ galactosidase, que atua hidrolizando o éster galactosídeo. O substrato mais comum para esta enzima é o X-GAL (5-bromo-4-cloro-3-indol- $\beta$-Dgalactosídeo), e em geral atua sob a indução de IPTG (isopropil $\beta$-Dtiogalactosídeo). A expressão da enzima $\beta$-galactosidase via um pigmento amarelo ou azul pode ser facilmente detectada por métodos espectrofotométricos e através de ensaios em placa de Petri, respectivamente (Melo et al., 2002). A utilização deste gene apresenta limitações, uma vez que bactérias, especialmente as pertencentes à família Enterobacteriaceae, são capazes de produzir naturalmente esta enzima.

O gene gusA (udi A) codifica a enzima bacteriana $\beta$-glicuronidase e foi descrito por Jefferson et al. (1987). Esta enzima catalisa a hidrólise de uma variedade de glicuronídeos. Os pigmentos resultantes desta hidrólise são então facilmente detectáveis. O substrato empregado para tal enzima é o X-GLUC (5- 
bromo-4-cloro-3-indol- $\beta$-D-glicuronídeo) e a sua hidrólise produz um pigmento azul. Os ensaios quantitativos de microrganismos endofíticos carregando o gene gus podem ser conduzidos em placas de Petri, usando substratos que liberam produtos coloridos como o pNPG (p-nitrofenol glicuronídeo) ou produtos fluorescentes como o MUG (umbeliferil glicuronídeo). Assim como lacZ, a detecção do gene gus necessita de um indutor IPTG associado ao X-GLUC . Da mesma forma, seu uso é limitado em bactérias pois algumas delas produzem naturalmente a enzima.

O gene gfp (green fluorescent protein) codifica uma proteína de cor verde fluorescente (GFP), encontrada na água-viva (Aequorea victoria) e de outros cnidários como Renilla reniformis e Obelia sp. (Gorokhovatsky et al., 2004). Na água-viva, a GFP é produzida em cromóforos (Figura 2). Essa proteína absorve luz ultravioleta (UV) a uma absorbância de 395 nm e emite luz verde a 509 nm. Colônias bacterianas expressando a proteína GFP podem ser visualizadas por meio de transiluminador de UV e de microscopia de fluorescência. A produção de GFP em células bacterianas pode assim ser quantificada por fluorescência (Melo et al., 2002).

O gene gfp pode ser facilmente inserido em vetores de expressão e apresenta inúmeras vantagens. Sua expressão não depende de co-fatores e não requer a adição de nenhum substrato além do oxigênio, facilitando o estudo do gene in situ e em tempo real. Desde o primeiro relato do uso de gfp como 
um gene repórter citológico por Chalfie et al. (1994), o interesse pela proteína GFP vem aumentando.

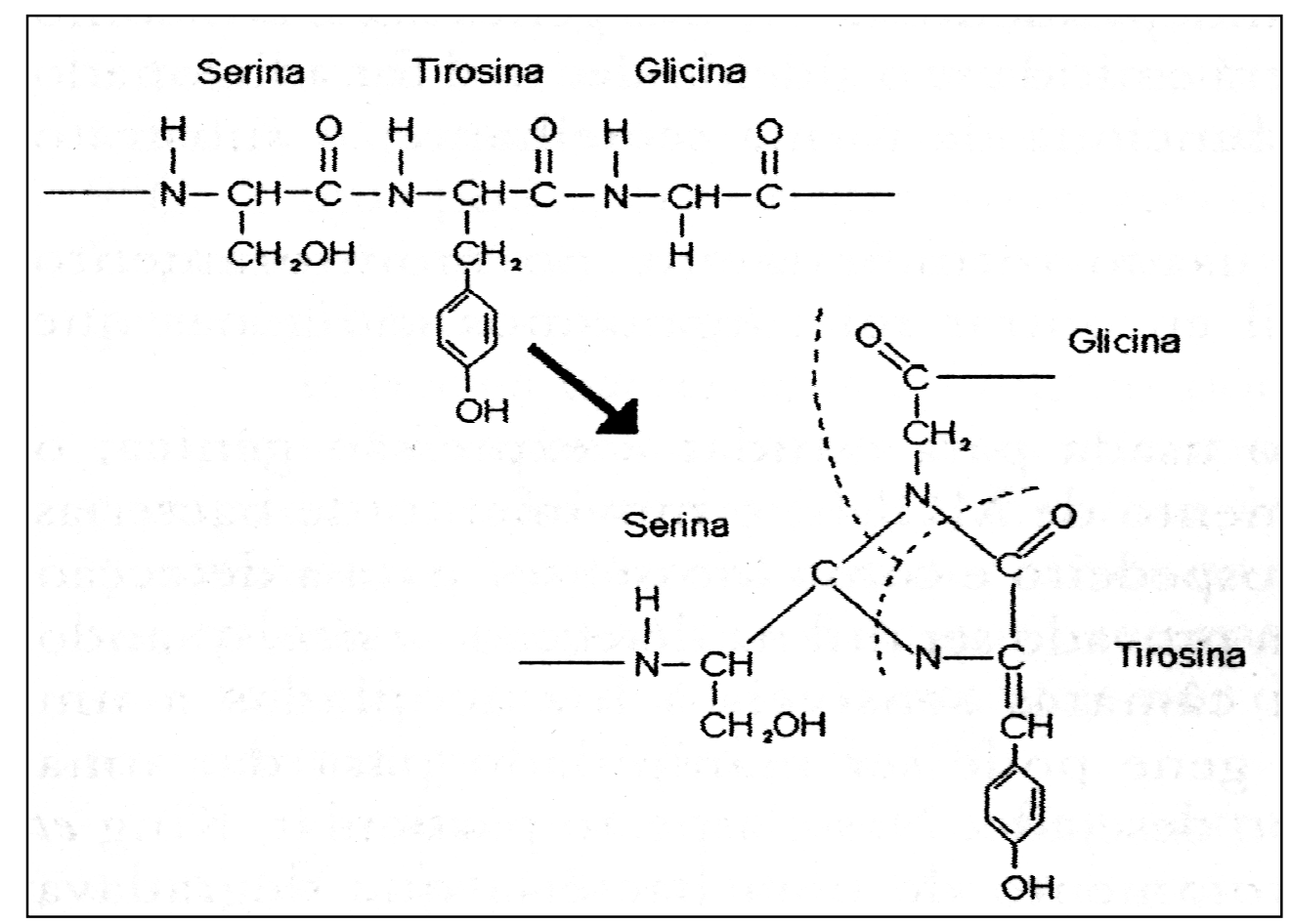

Figura 2 - Estrutura do cromóforo da proteína GFP de Aequorea victoria. Esta é a fonte de fluorescência visualizada. As linhas pontilhadas separam os aminoácidos do cromóforo (Melo et al., 2002)

\subsubsection{Genes repórteres em vetores de expressão em bactérias endofíticas}

A idéia de utilizar a interação simbiótica entre bactéria e plantas, aliada à engenharia genética, foi avaliada na bactéria endofítica Clavibacter xyli subsp. cynodontis, na qual foi introduzido o gene da endotoxina de $B$. thuringiensis (Fahey et al., 1991; Tomasino et al., 1995). Esta bactéria modificada geneticamente foi comercializada com o nome comercial de "Incide", o qual foi 
utilizado para o controle da broca do milho (Ostrinia nubilalis). Estratégia semelhante foi utilizada para o controle da broca da cana. Entretanto, foi verificado que o controle dessa broca foi mais eficiente quando duas espécies de bactérias endofíticas foram introduzidas na planta hospedeira, uma espécie com o gene da endotoxina de $B$. thuringiensis e outra bactéria com o gene que expressa uma enzima que degrada o exoesqueleto da lagarta, composto de quitina (Downing et al., 2000). Foi verificado que a presença deste gene de $B$. thuringiensis em C. xyli subsp. cynodontis não alterou a capacidade desta bactéria endofítica em colonizar colmos de milho. Em relação ao hospedeiro, observou-se que a presença deste endófito levava a um aumento na quantidade de nitrogênio na planta, independente da presença do gene exógeno. Não foi observada alteração na composição de nitrogênio dos resíduos das plantas no solo após inoculação. Entretanto, a bactéria alterada geneticamente induziu um acúmulo maior de água na planta hospedeira. Foi constatado também, que este endófito geneticamente manipulado não era capaz de sobreviver no solo, aumentando a possibilidade de sua utilização, visto que reduz riscos ambientais (Tester, 1992).

Foi também descrita a construção de um vetor integrativo que pode carregar genes exógenos para a utilização em C. xyli subsp. cynodontis. Neste trabalho, foi utilizado o gene que codifica a enzima endoglicanase, e verificouse que os transformantes foram estáveis in vitro e no xilema de milho, mostrando a possibilidade da utilização desta bactéria e deste vetor para o 
controle biológico de doenças e/ou outras pragas do milho (Haapalainen et al., 1998). Esta estratégia tem sido também utilizada para uma maior compreensão da interação bactéria-planta e o controle de doenças. Neste contexto, foi introduzido o gene repórter lacZY em linhagens de $P$. fluorescens e $P$. putida, as quais induzem resistência a $R$. solani em arroz. Utilizando este sistema, os autores monitoraram a migração e sobrevivência destas bactérias no interior dos tecidos do hospedeiro e, embora nenhuma bactéria tenha sido observada epifiticamente, foi constatada a redução dos sintomas causados por $R$. solani em até 18 vezes (Krishnamurthy \& Gnanamanickam, 1997).

Araújo et al. (2001) isolaram várias bactérias endofíticas de Citrus sinensis (laranja doce), e observaram que $P$. agglomerans representava uma das espécies mais freqüentes Esta bactéria endofítica tem uma ampla distribuição em citros e, uma vez reintroduzida na planta hospedeira por inoculação artificial, ela pode colonizar vários tecidos da planta. Tais características fazem de $P$. agglomerans um candidato para carregar genes que poderão ser úteis para o desenvolvimento de agentes de controle biológico. Posteriormente, um plasmídio críptico desta bactéria endofítica foi isolado, seqüenciado e utilizado para o desenvolvimento de um vetor de expressão para esta bactéria contendo a proteína GFP (Souza et al., 2000). Este gene repórter foi também utilizado em Azoarcus sp., no qual foi obtido um isolado com uma fusão dos genes repórteres gusA e gfp ao gene nifH, o qual após inoculação em plântulas de arroz, mostrou em condições de laboratório alta expressão de nifH 
em microcolônias localizadas no aerênquima do hospedeiro (Egener et al., 1999).

A continuidade do desenvolvimento de endófitos como agentes de controle biológico, e a utilização da biologia molecular com a ajuda de genes repórteres, poderão fornecer respostas para inúmeras perguntas a respeito do impacto destes microrganismos alterados geneticamente no ambiente, e nas culturas onde serão utilizados (Hallmann et al., 1997). 


\section{IDENTIFICAÇÃO DE ENTEROBACTÉRIAS ENDOFÍTICAS DE DIFERENTES PLANTAS hOSPEDEIRAS PELO USO DA ANÁLISE DE RESTRIÇÃO DO DNA RIBOSSÔMICO (rDNA) AMPLIFICADO E POR SEQÜENCIAMENTO DO rDNA}

\section{Resumo}

Bactérias endofíticas pertencentes à família Enterobacteriaceae foram caracterizadas por análise molecular de isolados de plantas de cacau, cana-deaçúcar, citros, eucalipto e soja. Dentre 68 isolados bacterianos, 20 haplótipos foram encontrados de acordo com a similaridade entre os perfis eletroforéticos obtidos por análise de restrição do 16S rRNA (ARDRA). A maioria dos isolados mostrou especificidade com o hospedeiro. Representantes dos principais haplótipos obtidos por ARDRA foram identificados por seqüenciamento do fragmento do rRNA 16S. Os resultados revelaram uma variedade de organismos e 5 gêneros diferentes foram obtidos. Pantoea foi o mais freqüente, seguido por Enterobacter e Erwinia, cujos isolados apresentaram grande diversidade bacteriana de acordo com as plantas hospedeiras. Tais resultados proporcionaram uma maior compreensão quanto à interação entre 
enterobactérias endofíticas e suas plantas hospedeiras, a qual será útil para futuramente responder questões básicas sobre o papel ecológico dos endófitos e seu potencial biotecnológico.

\section{Summary}

Endophytic bacteria belonging to Enterobacteriacea family were characterized by molecular analysis of isolates obtained from citrus, cocoa, eucalypti, soybean and sugar cane. Among the 68 bacterial isolates, 20 haplotypes were found according to the similarity of the banding profile obtained by amplified ribosomal DNA restriction analysis (ARDRA). Most haplotypes were restricted to the host plant. A subset of representative isolates for the main ARDRA haplotype was identified by $16 \mathrm{~S}$ rRNA gene fragment sequencing. Results showed a variety of organisms, with 5 different genera encountered: Pantoea was most frequently encountered followed by Enterobacter and Erwinia, which isolates presented the great bacterial diversity according to host plants. These results provided important insights in to the endophytic nterobacteria-host relationship that will be useful for further answer basic questions about the ecological role of the endophytes and its biotechnological potential. 


\subsection{Introdução}

Endófitos são todos aqueles microrganismos cultiváveis ou não que habitam o interior de tecidos de plantas sem causar doença às mesmas, nem formam estruturas externas, excluindo dessa forma bactérias noduladoras e fungos micorrízicos (Azevedo et al., 2000). Os endófitos incluem microrganismos comensais, que não exercem nenhum efeito direto sobre a planta hospedeira e simbiontes mutualistas, que poderão ser usados no controle biológico de pragas e patógenos ou promover crescimento da planta. $\mathrm{O}$ papel da comunidade endofítica nas associações endófito/planta tem sido extensivamente discutido (Sturz et al. 2000; Saikkonen et al., 2004). Bactérias endofíticas colonizam nicho ecológico similar àquele ocupado por fitopatógenos, especialmente patógenos vasculares. Este fato pode favorecer endófitos como candidatos para agentes de controle biológico (Hallmann et al. 1997). Uma alta diversidade de endófitos tem sido encontrada em diferentes plantas de importância econômica como arroz (Jiménes et al., 2003), cacau (Lana et al., 2004; Rubini et al., 2005); cana-de-açúcar (Boddey et al., 2003); citros (Araújo et al., 2001; Araújo et al., 2002); eucalipto (Procópio, 2004); milho (Araújo et al., 2000; Fisher \& Petrini, 1992; Estrada, 2002); soja (Kuklinsky-Sobral et al., 2004); trigo (Conn \& Franco, 2004), entre outros. No entanto, pouco é sabido sobre a diversidade de bactérias endofíticas da família Enterobacteriaceae ou sobre sua associação com a planta hospedeira. 
Historicamente, tem sido muito difícil determinar a diversidade de microrganismos que constituem ecossistemas naturais. Técnicas de DNA recombinante vêm sendo desenvolvidas e têm sido muito úteis para a identificação de bactérias, independente de métodos de cultivo (Theron \& Cloete, 2000). Algumas estratégias baseadas na identificação de microrganismos via seqüenciamento do gene do rDNA $16 S$ têm sido extensivamente utilizadas, especialmente para estudar diversidade de comunidades, pois o rDNA 165 é altamente conservado entre as espécies de procariotos (Woo et al., 2003).

A amplificação do rDNA 16 S por PCR, seguida da análise de restrição do rDNA 165 amplificado (Amplified Ribosomal DNA Restriction Analysis ARDRA), é capaz de identificar linhagens em nível de gênero ou espécie. Por isso, ARDRA é uma técnica muito utilizada em estudos filogenéticos e taxonômicos (Rodas et al., 2003). Além disso, ARDRA é mais rápido que seqüenciamento do rDNA 16S e menos oneroso (Gish et al., 2000, Procópio, 2004).

No presente estudo, uma estratégia molecular (análise por ARDRA e por seqüenciamento do rDNA 16S) foi utilizada para avaliar a diversidade genética de bactérias endofíticas pertencentes ao grupo de Enterobacteriaceae endofíticas de cinco diferentes plantas hospedeiras. De acordo com a estratégia adotada, o presente trabalho teve como objetivos: (i) selecionar amostras de bactérias cultiváveis pertencentes à família Enterobacteriaceae, obtidas de 
plantas de cacau, cana-de-açúcar, citros, eucalipto e soja; (ii) amplificar por PCR o gene do rDNA 165 de cada isolado; (iii) agrupar os isolados em haplótipos pela análise dos padrões de restrição, obtidos após a digestão do rDNA 16S amplificado com as enzimas de restrição Alul, Haelll, Mbol, as quais freqüentemente geram padrões espécie-específicos; (iv) identificar isolados pertencentes aos principais haplótipos de ARDRA pela seqüência do rDNA $16 S$ e caraterizar tais haplótipos de acordo com as espécies/gêneros identificados.

\subsection{Material e Métodos}

\subsubsection{Seleção de bactérias endofíticas fermentadoras de glicose}

Inicialmente, um total de 153 isolados de bactérias endofíticas foram analisados quanto à capacidade de fermentar glicose, sendo 23 isolados de cacau, 38 de cana-de-açúcar, 25 de citros, 16 de eucalipto e 51 de soja. Eles foram submetidos ao teste de oxidação e fermentação da glicose (O/F glicose), utilizado para identificar bactérias do grupo Enterobacteriaceae, as quais são fermentadoras de glicose. Os isolados foram inoculados com picada profunda em tubos de ensaio contendo o meio para teste de O/F [(2,2 g/l de peptona (Difco); 5,6 g/l de NaCl (Merck); 0,33 g/l de $\mathrm{KH}_{2} \mathrm{PO}_{4}$ (USB); 0,03 $\mathrm{g} / \mathrm{l}$ de azul de bromotimol (Merck); $10 \mathrm{~g} / \mathrm{l}$ de glicose (USB); 3,3 g/l de ágar (Merck); pH 6,8 $7,2)]$. 
Para a observação de fermentação, foram colocados $3 \mathrm{ml}$ de óleo mineral (Merk) esterilizado sobre a superfície do meio. A mudança de coloração do meio de verde para amarelo, após 72 horas de incubação a $28^{\circ} \mathrm{C}$, indicou a fermentação da glicose $(F)$. Entretanto, quando esta mudança ocorreu apenas na superfície do tubo sem óleo, houve oxidação da glicose (O).

\subsubsection{Isolados bacterianos selecionados e condições de cultivo}

As linhagens endofíticas de bactérias da família Enterobacteriaceae utilizadas no presente trabalho fazem parte da coleção do Laboratório de Genética de Microrganismos "Professor João Lúcio de Azevedo" - ESALQ/USP, e estão descritas na Tabela 1, de acordo com sua planta hospedeira. Araújo et al., 2002 (citros), Procópio, 2003 (eucalipto) e Kuklinsky-Sobral et al., 2004 (soja) obtiveram previamente a maioria dos isolados.

Os isolados bacterianos foram estocados em meio LB líquido [(Lúria Bertani - $10 \mathrm{~g} / \mathrm{l}$ de triptona (Difco); $5 \mathrm{~g} / \mathrm{l}$ de extrato de levedura (USB); $10 \mathrm{~g} / \mathrm{l} \mathrm{de}$ $\mathrm{NaCl}$ (Merck); $\mathrm{pH} 7,0)$ ], suplementado com $10 \%$ de glicerol (Merck) a $-70^{\circ} \mathrm{C} \mathrm{e}$ em frascos com meio LB sólido (ágar $1,5 \%$ ) a $4^{\circ} \mathrm{C}$. Para a produção de culturas novas, os isolados foram repicados em LB durante os experimentos. 
Tabela 1. Isolados de Enterobacteriaceae endofíticas utilizadas neste estudo e número de acesso dos isolados seqüenciados

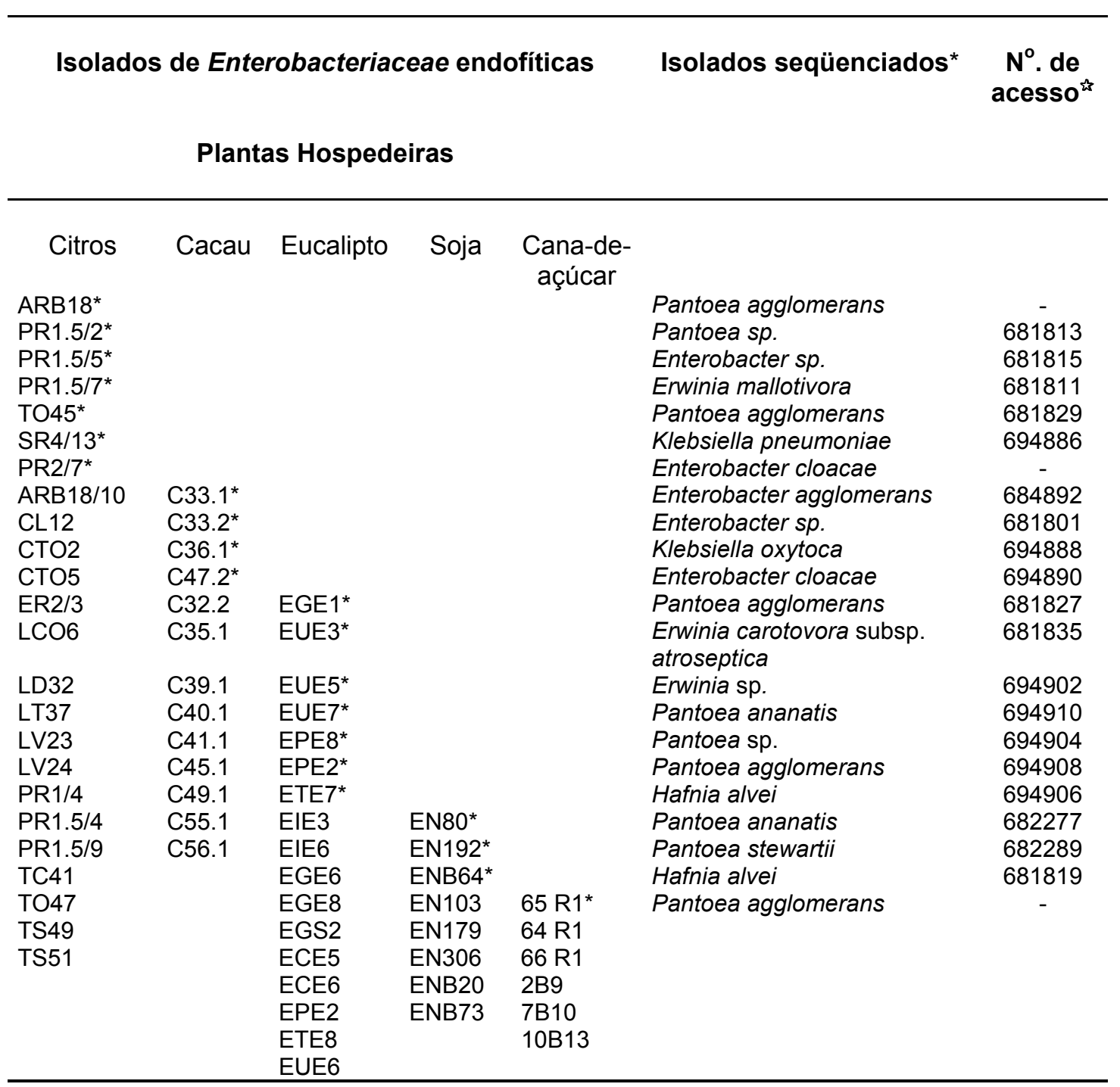

is Número de acesso provisório ao GeneBank 


\subsubsection{Extração de DNA genômico}

As linhagens foram cultivadas em $5 \mathrm{ml}$ de LB líquido por 24 horas a $28^{\circ} \mathrm{C}$ sob agitação (150 rpm). Um volume de 2 - $4 \mathrm{ml}$ da cultura foi centrifugado por 5 min a $14.000 \mathrm{~g}$ e as células ressuspendidas em $500 \mu \mathrm{l}$ de TE (10 Mm de Tris$\mathrm{HCl} ; \mathrm{pH} 8,0$ ), centrifugadas e ressuspendidas novamente em $500 \mu \mathrm{l}$ de TE com o acréscimo de 0,5 $\mathrm{g}$ de pérolas de vidro de 0,1 $\mathrm{mm}$ de diâmetro (Sigma) e 15 $\mu \mathrm{l}$ de SDS $20 \%$. As células foram agitadas em um homogeneizador (MineBeadbeater $^{\mathrm{TM}}$, Biospec Products) por $30 \mathrm{~s}$ a $3.500 \mathrm{bpm}$. Ao lisado celular foram adicionados $500 \mu \mathrm{l}$ de fenol, homogeneizados por inversão e centrifugados por 5 min a $14.000 \mathrm{~g}$. A fase aquosa foi extraída uma vez com fenol-clorofórmio (1:1) e uma vez com clorofórmio (Sigma); então, o DNA foi precipitado com 1/10 volume de $\mathrm{NaCl}$ (Merck) $5 \mathrm{M}$ e 0,6 volume de isopropanol (Merck) $3 \mathrm{~min}$ à temperatura ambiente e coletado por centrifugação $(10 \mathrm{~min}$ a $14.000 \mathrm{~g})$. $\mathrm{O}$ precipitado de DNA foi lavado com etanol (Merck) $70 \%$, seco a $37^{\circ} \mathrm{C}$ e ressuspendido em $50 \mu \mathrm{l}$ de água milli-Q esterilizada. O DNA total foi analisado por eletroforese em gel de agarose (Invitrogen) $(0,8 \%$ p/v) em tampão 1x TAE [(40 mM de Tris-acetato (Sigma); $1 \mathrm{mM}$ de EDTA (Sigma)] e corado com brometo de etídio (Sigma) (0,5 $\mu \mathrm{g} / \mathrm{ml})$, segundo Sambrook et al. (1989). 


\subsubsection{Amplificação do rDNA 16S}

A amplificação do rDNA $16 S$ foi realizada por meio da técnica de PCR utilizando-se os primers universais para bactérias P027F (5'GAGAGTTTGATCCTGGCTCAG-3') $\quad$ e $\quad$ 1378R CGGTGTGTACAAGGCCCGGGAACG-3'), que são específicos para o gene do rRNA 16S. As reações apresentaram um volume final de $50 \mu \mathrm{l}$ contendo 0,5 a $10 \mathrm{ng}$ de DNA molde; $0,2 \mu \mathrm{M}$ de cada primer; $0,2 \mathrm{mM}$ de cada dNTPs; 3,75 mM de $\mathrm{MgCl}_{2}$ e 0,5 $\mathrm{U}$ da enzima Taq DNA polimerase em $20 \mathrm{mM}$ de Tris- $\mathrm{HCl} \mathrm{pH}$ 8,4 e $50 \mathrm{mM} \mathrm{KCl}$, todos pertencentes à marca Invitrogen. Em todas as reações foi utilizado um controle negativo sem o DNA molde.

A reação de amplificação foi realizada em termociclador (Perkin-Elmer GeneAmp® PCR System 9700) programado para realizar uma desnaturação inicial a $94^{\circ} \mathrm{C}$ por 4 min, 25 ciclos de desnaturação a $94^{\circ} \mathrm{C}$ por $30 \mathrm{~s}$, anelamento a $63^{\circ} \mathrm{C}$ por 1 min e extensão de primers a $72^{\circ} \mathrm{C}$ por 1 min, seguida de extensão final a $72^{\circ} \mathrm{C}$ por 7 min. Após a amplificação, $5 \mu l$ da reação de PCR foram avaliados por eletroforese em gel de agarose (Invitrogen) (1,2\% p/v) em tampão 1x TAE. Em seguida, o gel foi corado com brometo de etídio (Sigma) $(0,5$ $\mu \mathrm{g} / \mathrm{ml})$, para visualização de um fragmento de aproximadamente $1.350 \mathrm{pb}$. 


\subsubsection{Procedimentos de ARDRA}

A variabilidade genética das bactérias endofíticas foi analisada utilizandose a técnica de ARDRA (Amplified Ribosomal DNA Restriction Analysis). Três enzimas de restrição foram selecionadas, Alul, Haelll e Mbol, segundo estudos prévios realizados em nosso laboratório com população bacteriana de soja (Kuklinsky-Sobral et al., 2004). Para o procedimento de ARDRA, $1 \mu \mathrm{g}$ do fragmento de $16 \mathrm{~S}$ rDNA amplificado foi digerido com as enzimas Alul, Haelll e Mbol separadamente, de acordo com as recomendações do fabricante (Invitrogen). Após a digestão, toda a reação foi analisada por eletroforese em gel de agarose (Invitrogen) $(2,5 \% \mathrm{p} / \mathrm{v})$ em tampão $1 \mathrm{x}$ TAE por $4 \mathrm{~h}$ a $80 \mathrm{~V}$, juntamente com o marcador de peso molecular DNA Ladder 100 pb (IBM Fermentas). Em seguida, o gel foi corado com brometo de etídio (Sigma) $(0,5$ $\mu \mathrm{g} / \mathrm{ml}$ ) por $15 \mathrm{~min}$, observado sobre luz ultravioleta e fotografado utilizando-se o sistema Gel Doc 2000 (Bio-Rad). As imagens foram capturadas e salvas diretamente como documentos do tipo TIFF e processadas pelo programa BioNumerics 3.0 (Applied Maths). Matrizes de similaridade de curvas densiométricas foram calculadas utilizando-se o coeficiente de correlação de Jaccard. Os perfis eletroforéticos obtidos com cada enzima foram combinados para a obtenção de um perfil único para cada isolado. Os perfis foram usados para a construção de um dendrograma, utilizando o algoritmo UPGMA 
(Unweighted Pair Group Method with Arithmetic mean). Os isolados que apresentaram o mesmo perfil foram agrupados para formarem haplótipos. Após a distribuição dos isolados de acordo com seus haplótipos e planta hospedeira (Tabela 2), a diversidade bacteriana foi calculada para cada planta hospedeira pelo índice de diversidade de Shannon $(\mathrm{H})$. Para o cálculo do índice de diversidade (ver Figura 3), a seguinte equação foi utilizada: $H=1 / N \Sigma-(\log N i-$ $\log N) N i$, onde $N$ corresponde ao número total de isolados em uma planta hospedeira e Ni corresponde ao número de isolados de um único haplótipo, de acordo com Lagacé et al. (2004), com modificações.

\subsubsection{Seqüenciamento do rDNA $16 \mathrm{~S}$ e análise das seqüências}

Os produtos de PCR do rDNA $16 \mathrm{~S}$ de um a três isolados representantes dos quinze principais haplótipos foram purificados usando o kit GFX PCR DNA (Amersham Biosciences) e enviados para seqüenciamento parcial do 16S rDNA com o primer 1378R, no laboratório do Dr. Ricardo Harakava (Instituto Biológico-SP) e no laboratório da Dra. Helaine Carrer (CBTEC/ESALQ/USP). As seqüências foram analisadas pelo algoritmo BLASTn contra a base de dados do NCBI (National Center for Biotechnology Information http://www.ncbi.nlm.nih.gov). As seqüências obtidas foram depositadas no banco de dados do NCBI, e os números de acesso estão mostrados na Tabela

1. O alinhamento das seqüências foi feito utilizando o programa ClustalW, do 
EMBL (European Bioinformatics Institute - http://www.ebi.ac.uk/clustalw/). As matrizes de similaridade das árvores filogenéticas foram calculadas de acordo com Jukes \& Cantor (1969). Os algoritmos de neighbour-joining (Saitou \& Nei, 1987), e as análises de bootstrap com 1000 repetições foram feitas usando o programa PAUP (Swofford, 2002).

\subsection{Resultados}

\subsubsection{Análise de ARDRA}

Um total de 68 isolados de enterobactérias endofíticas foram analisados (Tabela1), os quais foram submetidos à análise de ARDRA pela digestão do rDNA 165 com as enzimas Alul, Haelll e Mbol. Para isso, cada perfil eletroforético encontrado foi comparado com todos os outros, permitindo assim o reconhecimento de 20 diferentes perfis, ou haplótipos de ARDRA. Dessa forma, padrões semelhantes obtidos após a combinação de três digestões independentes foram agrupados para finalmente obter um total de 20 haplótipos (Figura 1). Como mostrado na Tabela 2, cada haplótipo apresentou um padrão de bandas específico. A relação por ARDRA entre os isolados endofíticos de enterobactérias está demostrada na Figura 1, na qual os isolados foram agrupados em seis diferentes grupos de acordo com seu hospedeiro vegetal. $\mathrm{O}$ primeiro grupo (I) foi predominantemente formado por isolados de cacau, exceto 


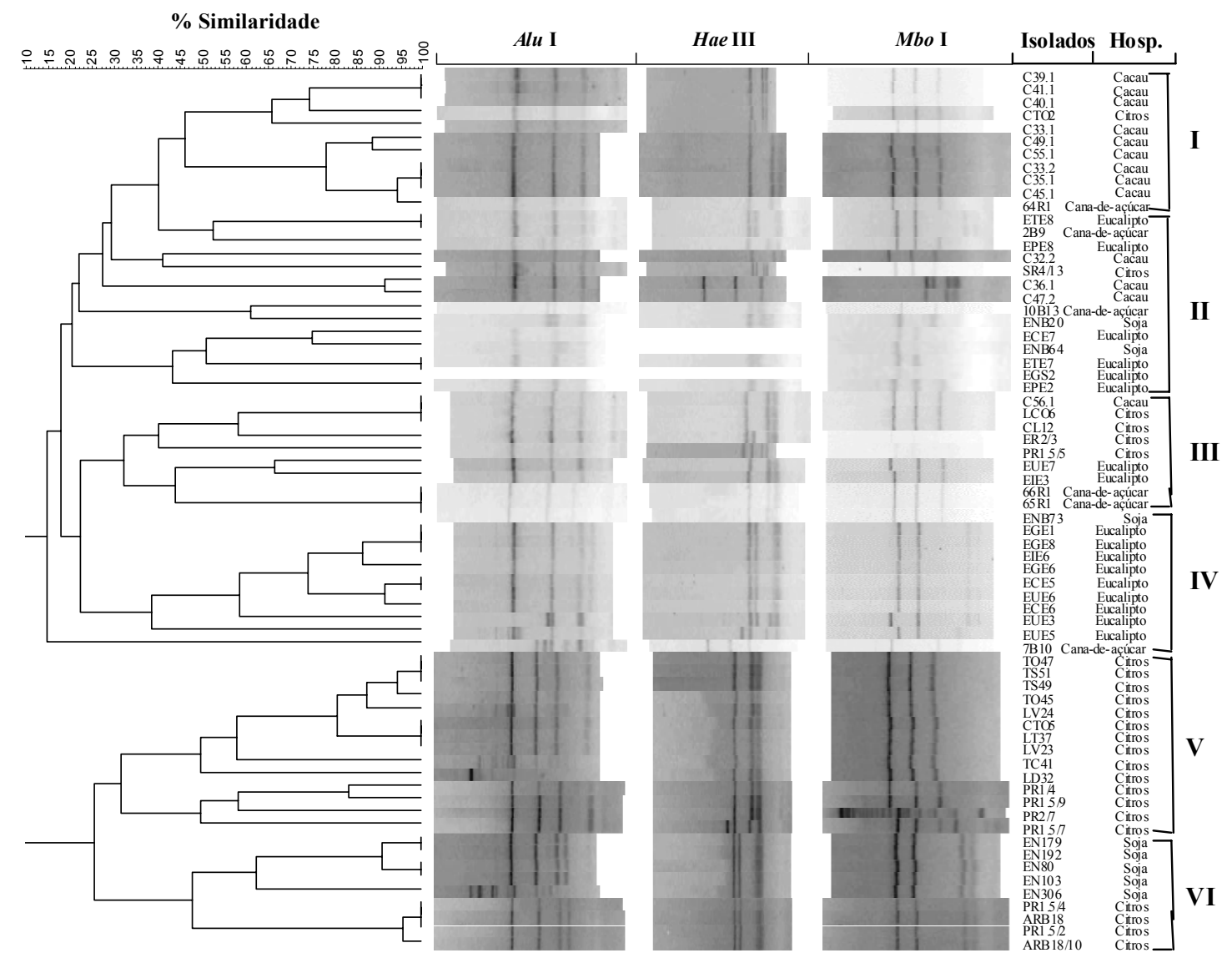

Figura 1 - Dendrograma gerado a partir de ARDRA em gel de agarose ilustrando a relação (\% de similaridade) entre isolados de enterobactérias endofíticas. As bandas de ARDRA foram obtidas por digestão independente do produto amplificado do gene do rRNA $16 \mathrm{~S} \mathrm{com}$ as endonucleases Alul, Haelll e Mbol. O dendrograma foi construído utilizando-se o pacote de programas BioNumerics e agrupado por UPGMA. Em algarismo romano estão representados os grupos de acordo com a planta hospedeira 
pela presença de um isolado de citros (CTO2) e um de cana-de-açúcar (64R1). O segundo grupo (II) foi o mais heterogêneo, incluindo isolados de todos os cinco hospedeiros estudados. O terceiro grupo (III) foi predominantemente constituído por isolados de citros, eucalipto, e cana-de-açúcar, exceto pela presença de um isolado de cacau (C56.1). Já o quarto grupo (IV) foi constituído em sua maioria por isolados de eucalipto, mas incluiu também um isolado de soja (ENB73) e outro de cana-de-açúcar. O quinto grupo (V) foi exclusivamente formado por isolados de citros. O sexto e último grupo (VI) foi constituído por isolados de soja e citros, formando dois subgrupos distintos. Representantes de 15 haplótipos foram selecionados para o seqüenciamento de seu gene de rRNA $16 S$ e posterior comparação de suas seqüências com àquelas presente em banco de dados (Tabela1).

\subsubsection{Distribuição e diversidade de isolados de enterobatérias endofíticas}

A distribuição dos endofíticos de acordo com haplótipos e planta hospedeira (Tabela 2) revelou que os haplótipos A e B tiveram o maior número de isolados, os quais pertenceram aos gêneros Enterobacter e Pantoea, respectivamente. Conforme mostrado na Tabela 2, estes dois haplótipos compreendem $49 \%$ (33) do total de isolados analisados. Os haplótipos C e D também foram freqüentes, compreendendo um total de $22 \%$ (15) dos isolados. 
Os outros 16 haplótipos não contaram com mais de $3 \%$ (2) isolados, quando avaliados separadamente.

Tabela 2. Distribuição de isolados de enterobactérias endofíticas de acordo com o haplótipo de ARDRA e padrão de restrição

\begin{tabular}{|c|c|c|c|c|c|c|c|c|}
\hline \multirow[t]{2}{*}{ Haplótipos } & \multicolumn{3}{|c|}{$\begin{array}{l}\text { Perfis de ARDRA de } \\
\text { acordo com a } \\
\text { enzima de restrição } \\
\text { utilizada }\end{array}$} & \multicolumn{5}{|c|}{$\begin{array}{l}\mathbf{N}^{\circ} \text { de isolados de enterobactérias endofíticas por haplótipo } \\
\text { sua freqüência por planta hospedeira (\%) }\end{array}$} \\
\hline & Alu I & Hae III & Mbo I & Citros & Cacau & Eucalipto & Soja & $\begin{array}{l}\text { Cana-de- } \\
\text { açúcar }\end{array}$ \\
\hline A & 1 & 1 & 1 & $16(66,63)$ & - & - & - & - \\
\hline B & 2 & 2 & 2 & $1(4,16)$ & $11(84,62)$ & $1(5,89)$ & $1(12,50)$ & $3(50,00)$ \\
\hline C & 1 & 2 & 2 & $3(12,53)$ & - & - & $5(62,50)$ & - \\
\hline D & 1 & 6 & 1 & & - & $7(41,10)$ & - & - \\
\hline E & 1 & 5 & 1 & $2(8,36)$ & - & - & - & - \\
\hline $\mathrm{F}$ & 2 & 3 & 6 & - & - & $1(5,89)$ & - & $1(16,67)$ \\
\hline G & 1 & 3 & 5 & $1(4,16)$ & - & $1(5,89)$ & - & - \\
\hline $\mathrm{H}$ & 2 & 2 & 6 & - & - & $1(5,89)$ & - & - \\
\hline I & 3 & 6 & 3 & - & - & $1(5,89)$ & - & - \\
\hline $\mathrm{J}$ & 2 & 2 & 1 & - & - & $1(5,89)$ & - & - \\
\hline $\mathrm{L}$ & 4 & 1 & 6 & - & - & $1(5,89)$ & - & - \\
\hline M & 5 & 4 & 4 & - & - & $1(5,89)$ & - & - \\
\hline$N$ & 2 & 3 & 10 & $1(4,16)$ & - & - & - & - \\
\hline 0 & 2 & 1 & 8 & - & - & - & $1(12,50)$ & - \\
\hline$P$ & 6 & 1 & 10 & - & - & $1(5,89)$ & - & - \\
\hline Q & 2 & 2 & 1 & - & - & $1(5,89)$ & - & - \\
\hline $\mathrm{R}$ & 8 & 5 & 6 & - & - & - & - & $1(16,67)$ \\
\hline$S$ & 1 & 7 & 1 & - & $1(7,69)$ & - & - & - \\
\hline$T$ & 1 & 6 & 2 & - & $1(7,69)$ & - & - & - \\
\hline U & 5 & 1 & 10 & - & & & $1(12,50)$ & $1(16,67)$ \\
\hline Total & & & & $24(100,0)$ & $13(100,0)$ & $17(100,0)$ & $8(100,0)$ & $6(100,0)$ \\
\hline
\end{tabular}


No entanto, em conjunto, compreenderam $29 \%$ (20) de todos os isolados analisados. Considerando a freqüência dos haplótipos de acordo com a planta hospedeira, o haplótipo A foi constituído exclusivamente de isolados de citros, e tal haplótipo foi representado por $67 \%$ de todos os isolados de citros. Por outro lado, o haplótipo B contou com representantes das cinco plantas hospedeiras em diferentes proporções, uma vez que os isolados de cacau compreenderam $65 \%$ (11) do total de isolados neste haplótipo, e $85 \%$ do total de isolados de cacau analisados. Cada um dos haplótipos $E, G$ e $U$ foi representado por apenas dois isolados. O haplótipo E foi representado por dois isolados de citros, constituindo $8 \%$ do total de isolados de citros. O haplótipo $\mathrm{G}$ foi representado por um isolado de citros e um isolado de eucalipto, enquanto que o haplótipo $U$ foi representado por um isolado de cana-da-açúcar e um de soja. Os haplótipos remanescentes incluíram isolados de todas as cinco plantas hospedeiras estudadas; embora eucalipto tenha exibido uma maior diversidade destes haplótipos remanescentes (6) e tenha sido a planta hospedeira com a maior diversidade de haplótipos como um todo.

A diversidade dos haplótipos de acordo com a planta hospedeira foi então organizada da seguinte forma: maior diversidade para eucalipto (11 haplótipos diferentes); seguida de citros (6); soja (4) e cana-de-açúcar (4) e cacau (3). Eucalipto foi representado por oito haplótipos exclusivos (D, H, I, J, L, $M, P$ e $)$. 
As demais plantas hospedeiras também tiveram seus haplótipos exclusivos, como citros (E e N); cacau ( $\mathrm{S}$ e T); soja ( $\mathrm{O}$ e U) e cana-de-açúcar (R). De acordo com os dados apresentados na Figura 2, a diversidade foi maior para isolados de cacau e menor para isolados de soja, conforme indicado pelo índice de diversidade de Shannon.

\subsubsection{Seqüenciamento parcial do rDNA 165 dos isolados de enterobactérias endofíticas}

Após o seqüenciamento do rDNA $16 S$ dos isolados representantes dos quinze principais haplótipos, foram obtidas quinze seqüências; as quais foram alinhadas e analisadas pelo algoritmo BLASTn e programa ClustalW, sendo construída uma árvore filogenética (Figura 2). A árvore filogenética revelou que os quinze principais haplótipos foram representados por cinco gêneros bacterianos: Enterobacter, Enwinia, Hafnia, Klebsiella e Pantoea, os quais incluíram nove espécies diferentes (Tabela 1). 


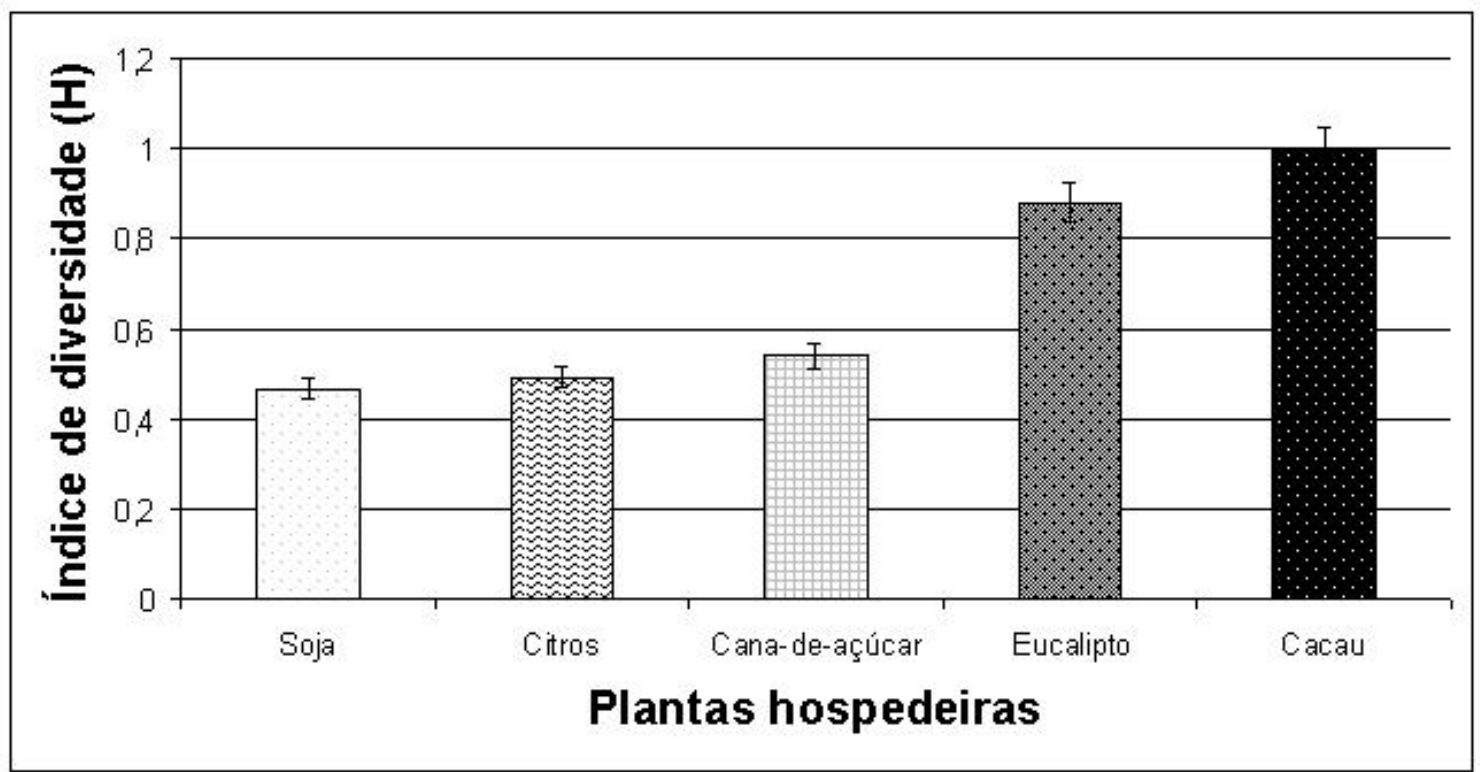

Figura 2 - Diversidade de isolados de enterobactérias endofíticas de cacau, cana-de-açúcar, citros, eucalipto e soja usando o índice de diversidade de Shannon $(\mathrm{H})$ 
De acordo com a Figura 3 , os isolados foram agrupados em sete diferentes grupos. O primeiro deles (grupo 1) foi constituído por isolados cujas seqüências mostraram similaridade com grupo de Enterobacter e Pantoea, com maior similaridade com Enterobacter sp. (98\%), (acesso $\left.\mathrm{n}^{\circ} \mathrm{AB} 114268\right)$. 0 segundo grupo (2) mostrou grande similaridade com o grupo de Klebsiella, com maior similaridade $(97 \%)$ com K. oxytoca (acesso $n^{\circ}$ KOY17655). O grupo 3 apresentou grande similaridade com a espécie Hafnia alvei (98\%), (acesso $\mathrm{n}^{\circ}$ AY253922). O quarto grupo (4) revelou maior similaridade de seqüências com Erwinia (97\%). Os grupos 5 e 6 revelaram grande similaridade com o grupo de Enterobacter-Pantoea, com maior similaridade (97\%) com P. agglomerans (acesso $\mathrm{n}^{\circ} \mathrm{AB004961)}$ do banco de dados. $O$ grupo 7 foi formado por apenas 2 isolados de citros (PR1.5/2 e PR1.5/5), com maior similaridade com Enterobacter sp (97\%) e Pantoea sp. (97\%) números de acesso do banco de dados AF364846 e AY395009, respectivamente (dados não mostrados). Segundo a Figura 3, isolados pertencentes aos haplótipos $B, N$ e $T$ foram agrupados com o grupo das Enterobacter. O isolado C33.1 mostrou-se muito similar (98\%) a Enterobacter sp. (acesso $\mathrm{n}^{\circ} \mathrm{AB} 114268$ ). Os isolados pertencentes aos haplótipos A e G foram agrupados de acordo com a similaridade mostrada pela análise de ARDRA, porém suas seqüências alinharam com Pantoea agglomerans, com 97\% de similaridade (acesso $n^{\circ}$ AB004961) e Erwinia sp., com 97\% de similaridade) (acesso n AY660693), respectivamente. 


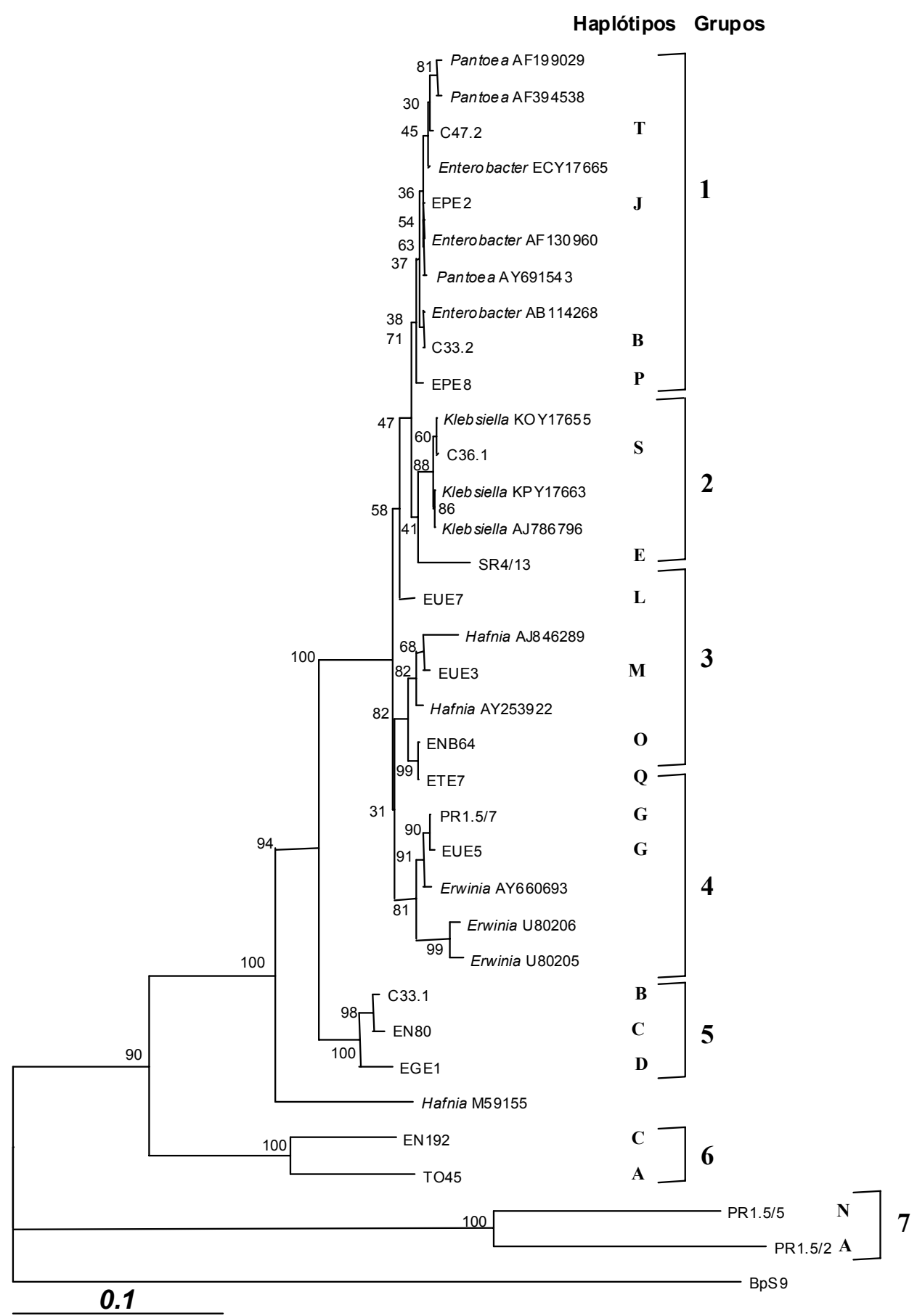

Figura 3 - Árvore filogenética baseada nas seqüências parciais do rDNA 165 obtidas de isolados de enterobactérias endofíticas e seqüências intimamente relacionadas. O bootstrap da árvore consenso foi construído utilizando-se UPGMA. Bacillus pumilus linhagem S9 (acesso $\mathrm{n}^{\circ}$ AY548955) foi usada como outgroup. Os números arábicos representam os grupos de bactérias, enquanto que as letras representam os haplótipos. A escala significa 0,1 substituição de nucleotídeos por sítio 
Representantes dos haplótipos C, D, J, L e P foram colocados no grupo das Enterobacter, os quais apresentaram similaridade de 97-99\%.

Isolados dos haplótipos O e Q agruparam com $H$. alvei, com 96\% de similaridade. Por outro lado, o representante do haplótipo M (Erwinia carotovora) foi colocado no mesmo grupo de Hafnia, com $100 \%$ de similaridade. Os representantes dos haplótipos E e S agruparam com Klebsiella.

\subsection{Discussão}

O estudo das estruturas genéticas de bactérias endofíticas que desempenham um papel benéfico na fisiologia das plantas hospedeiras tem sido extensamente revisado (Selosse et al., 2004; Azevedo et al., 2003; Long et al., 2003; Surette et al., 2003; Elbeltagy et al., 2001; Elvira-Recuendo \& Van Vurde, 2000). Pouco ainda é sabido sobre o papel da interação entre bactérias endofíticas da família Enterobacteriaceae e seus hospedeiros.

Neste trabalho, reportou-se a caracterização molecular de 68 bactérias Enterobacteriaceae endofíticas isoladas de plantas de cacau, cana- de- açúcar, citros, eucalipto e soja, pelo uso da combinação de técnicas baseadas em amplificação e restrição do rDNA 16S.

Análises do padrão de restrição do rDNA $16 S$ com as enzimas Alul, Haelll e Mbol permitiram agrupar os 68 isolados em 20 haplótipos diferentes, os quais corresponderam a nove espécies, pertencentes a cinco diferentes 
gêneros. Ainda que os haplótipos A e B tenham compreendido mais de dez isolados cada, a grande maioria dos haplótipos foi composta por somente um ou dois isolados. De forma semelhante, Michaud et al., (2004), trabalhando com bactérias marinhas psicrófilas, também encontraram poucos isolados na maioria de seus haplótipos obtidos por ARDRA. Baseado nas análises de ARDRA, observou-se uma alta especificidade entre o isolado e seu hospedeiro, extremamente evidente para citros, cacau e eucalipto. Estes isolados parecem ser estritamente associados aos seus hospedeiros. Os resultados de ARDRA para isolados de soja mostraram que os isolados do tipo EN e ENB se separaram em diferentes grupos (VI e II-IV, respectivamente). Isto pode ser devido à forma como tais isolados foram obtidos por Kuklinsky-Sobral et al (2004). De fato, os isolados do tipo EN foram obtidos em meio contendo o fungicida Imazalil, enquanto que os isolados do tipo ENB foram isolados em meio contendo o fungicida Benomil. Na verdade poder-se-ia ter selecionado tipos diferentes de isolados de acordo com o fungida utilizado.

Sabe-se que cana-de-açúcar e eucalipto são cultivados por propagação de clones (Jackson et al., 1995; Coutinho et al., 2002; Almeida et al., 2004). Ambos, cana-de-açúcar e eucalipto, exibiram alta diversidade de haplótipos de acordo com a planta hospedeira. Isto sugere que as enterobactérias endofíticas isoladas destes hospedeiros, ao contrário do que se poderia imaginar, não são clonais. É possível que rearranjos genéticos em diferentes linhagens da mesma espécie possam ter ocorrido. Resultados semelhantes a estes foram 
encontrados por Mocali et al., (2003) em trabalho realizado com bactérias endofíticas de Ulmus spp., uma planta também de propagação clonal. Essa observação poderia indicar que uma diversidade genética mais alta nestes isolados permitiria aos mesmos um maior potencial para interagir com diferentes plantas hospedeiras.

Estudos posteriores poderiam ser realizados com um número maior de isolados de cana-de-açúcar a fim de suportar esta afirmativa. Mocali et al., (2003) também observaram um alto grau de variabilidade genética inter-específica em vários isolados pertencentes aos seus principais haplótipos de ARDRA. Este grau de divergência nas seqüências do rDNA $16 S$ sugere que bactérias pertencentes a alguns haplótipos, tais como A, C, D (Pantoea) e B (Enterobacter), constituem diferentes espécies. No entanto, a classificação de isolados bacterianos em nível de espécie requer posterior caracterização, a qual esta além do escopo deste trabalho.

Baseado na análise do seqüenciamento do rDNA 16S, os gêneros Enterobacter e Erwinia foram relativamente freqüentes. Contudo o gênero que predominou foi Pantoea. Araujo et al. (2001) também encontraram Pantoea como o gênero prevalecente em isolados de citros, enquanto que KuklisnkySobral et al (2004) e Procópio (2004) observaram Enterobacter e Erwinia como endófitos em soja e eucalipto, respectivamente. Da mesma forma, Lacava et al. (2004) também encontraram Enterobacter e Pantoea como isolados endofíticos de citros. 
A análise por seqüenciamento do rDNA 165 foi capaz de diferenciar os gêneros Klebsiella e Erwinia de outros, além de discriminar outros gêneros e espécies de bactérias das plantas hospedeiras estudadas. Os resultados revelaram também a presença de Hafnia em eucalipto e soja, um gênero até então não descrito como endofítico.

No presente estudo, a combinação das técnicas de ARDRA e seqüenciamento do rRNA $16 \mathrm{~S}$ permitiu análise mais acurada dos resultados. Embora não tenha sido possível discriminar os isolados de Pantoea e Enterobacter, eles foram reunidos nos grupos 1, 5 e 7. Outros autores também tiveram dificuldades para discriminar estes gêneros, uma vez que Enterobacteriaceae engloba espécies intimamente relacionadas (Hoffmann \& Roggenkamp, 2003).

Segundo di Cello et al. (1997), existe uma grande diversidade genética entre os microrganismos capazes de colonizar diferentes habitats. Portanto, a habilidade de tais bactérias colonizarem diferentes hospedeiros provavelmente é conferida por uma grande diversidade genética. Este fato revela que existe alto grau de diversidade genética interespecífica, sugerindo que várias espécies bacterianas são capazes de se adaptarem a diferentes condições, de acordo com a planta hospedeira. Dessa forma, os resultados obtidos nesse trabalho demonstraram grande diversidade entre os isolados de Enterobacteriaceae endofíticas, obtidas a partir de diferentes plantas hospedeiras de grande valor econômico. O presente estudo revelou grande diversidade genética desta 
comunidade microbiana por meio de perfis de ARDRA observados em relação à planta hospedeira. Após seqüenciamento de parte do rDNA 16S, foi revelada a identidade dos representantes dos principais grupos de ARDRA. Embora as plantas hospedeiras tenham apresentado haplótipos diferentes, membros do gênero Pantoea foram dominantes nas mesmas. Foi observada também presença de Hafnia endofítica, a qual não tinha sido relatada anteriormente. Além disso, uma alta diversidade genética entre os isolados de citros foi encontrada.

Finalmente, os resultados obtidos neste trabalho são de grande valor para o conhecimento da interação entre Enterobacteriaceae endofíticas e respectivas plantas hospedeiras. Tal conhecimento poderá ser útil para futuramente responder questões básicas sobre o papel dos endófitos e seu potencial biotecnológico.

\subsection{Conclusões}

Os resultados apresentados permitiram concluir que:

a) os isolados de enterobactérias endofíticas de cacau, cana-de-açúcar, eucalipto, citros e soja foram identificados como pertencentes aos gêneros Enterobacter, Erwinia e Pantoea, sendo este último o mais freqüente; 
b) os isolados de cacau, citros e eucalipto apresentaram alta especificidade com a planta hospedeira;

c) os isolados de cana-de-açúcar e eucalipto não são clonais, pois exibiram grande diversidade de acordo com a planta hospedeira;

d) foi observada também presença de Hafnia endofítica, a qual não tinha sido relatada anteriormente. 


\section{DIVERSIDADE DE ENTEROBACTÉRIAS ENDOFÍTICAS DE PLANTAS BRASILEIRAS DE GRANDE IMPORTÂNCIA ECONÔMICA}

\section{Resumo}

Um total de 53 isolados de enterobactérias endofíticas de cacau, canade-açúcar, citros, eucalipto e soja foram caracterizados quanto à sensibilidade aos antibióticos ampicilina e canamicina e quanto à produção de celulase. Foi detectada sensibilidade a ambos os antibióticos testados, a qual variou segundo a planta hospedeira somente para ampicilina, uma vez que todos os isolados foram sensíveis à canamicina. A produção de celulase também variou de acordo com a planta hospedeira. A diversidade destes isolados foi estimada usando a técnica de fingerprint genômico por BOX-PCR. Um total de 23 diferentes OTUs (operational taxonimic units) foi identificado, usando o nível de $60 \%$ de similaridade para definir uma OTU. A presença de 23 OTUs poderia indicar que os 53 isolados compreendiam pelo menos 23 espécies diferentes pois, de acordo com análise por BOX-PCR, OTUs é uma definição alternativa para espécies. Neste trabalho, isolados previamente identificados, representantes de sete diferentes OTUs, pertenceram à espécie Pantoea 
agglomerans, exceto $P$. ananatis e Hafnia alvei. Isto sugere que a maioria das OTUs observadas no presente trabalho são subspécies $P$. agglomerans.

\section{Summary}

Fifty-three endophytic enterobacteria isolates from Citros, cocoa, Eucalipto, Soja and sugar cane were evaluated to susceptibility to the antibiotics ampicillin and kanamycin, and cellulase production. Susceptibility to both antibiotics tested was found, which changed according to the host plant only for ampicillin, since all isolates were susceptible to kanamycin. The cellulase production also changed according to the host plant. The diversity of these isolates was estimated by employing BOX-PCR genomic fingerprints. A total of 23 distinct operational taxonimic units (OTUs) were identified by employing a criterion of $60 \%$ fingerprint similarity as a surrogate for an OTU. The presence of 23 OTUs could indicate that the 53 isolates comprised at least 23 different species, since when microbial diversity is inferred from BOX-PCR, individual OTUs must be defined as species surrogates. Herein isolates representatives seven different OTUs previously identified, belonged to Pantoea agglomerans specie, except $P$. ananatis and Hafnia alvei. It suggests that most OTUs observed in our work are actually subspecies of to $P$. agglomerans. 


\subsection{Introdução}

O estudo da diversidade genética de microrganismos endofíticos não só é importante para entender seu papel ecológico em ambientes naturais, mas também sua aplicação biotecnológica (Wise et al., 1996). O destino e distribuição das espécies em um ambiente natural podem, em parte, ser governados por meio da diversidade dentro das espécies; consequentemente, é necessário avaliar esta diversidade. Várias técnicas moleculares de fingerprinting de alta-resolução têm sido usadas para analisar diversidade de espécies e de subespécies (Rademaker et al., 2000; Schloter et al., 2000; Vaneechoutee et al., 1996). Técnicas de ribotipagem, seqüências repetitivas de DNA e PCR (Carson et al., 2003; Dombek et al., 2000) têm sido aplicadas com sucesso para agrupar bactérias das famílias Enterobacteriacea, Rhizobiaceae e Actinobacteridae,de acordo com tipo de planta hospedeira (Yang et al., 2004; Terasawa et al., 2003; Davelos et al., 2004). BOX-PCR é uma técnica baseada em primers que se anelam a seqüências de DNA repetitivas altamente conservadas, da subunidade BOX A do elemento BOX de bactérias (Rademaker et al., 2000). Além disso, a técnica de BOX-PCR baseia-se no fato de que primers de oligonucleotídeos complementares a seqüências repetitivas intercaladas, são capazes de amplificar fragmentos de DNA de diferentes tamanhos, que se anelam a tais elementos (Lanoot et al., 2004). BOX-PCR foi aplicado em alguns estudos taxonômicos de bactérias associadas à planta 
(Berg et al., 2002; Rademaker et al., 2000), porém somente dois estudos foram realizados com bactérias endofíticas (Verma et al., 2001, Krechel et al., 2002) e nenhum foi feito para analisar exclusivamente bactérias endofíticas da família Enterobacteriacea.

O presente trabalho teve como objetivos (i) avaliar a produção de celulase (endoglicanase) e a sensibilidade a antibiótico de enterobactérias endofíticas de plantas de cacau, cana-de-açúcar, citros, eucalipto e soja; (ii) analisar a diversidade destes isolados endofíticos pela técnica de fingerprinting do DNA genômico por BOX-PCR.

\subsection{Material e Métodos}

\subsubsection{Isolados bacterianos e condições de cultivo}

Os isolados bacterianos utilizados neste trabalho estão descritos na Tabela 1. Todos os isolados indicados como pertencentes à ESALQ/USP fazem parte da coleção de bactérias endofíticas do Laboratório de Genética de Microrganismos "Prof. João Lúcio de Azevedo" ESALQ/USP. Os isolados foram crescidos em meio LB [Luria Bertani - $10 \mathrm{~g} / \mathrm{l}$ de triptona (Difco); $5 \mathrm{~g} / \mathrm{l}$ extrato de levedura (USB); $10 \mathrm{~g} / \mathrm{l}$ de $\mathrm{NaCl}$ (Merck); $\mathrm{pH} 7,0$ ] por $18 \mathrm{~h}$ a $28^{\circ} \mathrm{C}$ sob agitação (200 rpm). 


\subsubsection{Teste de sensibilidade a antibiótico}

A sensibilidade dos 53 isolados de enterobactérias endofíticas a antibióticos foi determinada da seguinte forma: bactérias foram crescidas em meio LB até atingirem $5 \times 10^{5} \mathrm{CFU} / \mathrm{ml}$, de acordo com as diretrizes do National Committee for Clinical Laboratory Standards (NCCLS, 2004). A cultura foi então inoculada em placas de Petri contendo meio LB sólido (ágar 1,5\%) suplementado com antibióticos, utilizando replicador manual de 16 pinos. Foram utilizadas soluções aquosas de ampicilina (USB) e canamicina (USB), nas concentrações seletivas de 50 e $100 \mu \mathrm{g} / \mathrm{ml}$.

\subsubsection{Teste de produção de endoglicanase}

Foram executados ensaios em placa de Petri de acordo com o método descrito por Teather e Wood (1982). Com auxílio de palito, colônias isoladas das 53 culturas bacterianas foram inoculadas em LB suplementado com 1,5\% $\mathrm{p} / \mathrm{v}$ de carboxi-metil-celulose (CMC) (Sigma). As placas foram então incubadas por $24 \mathrm{~h}$ a $28^{\circ} \mathrm{C}$. Após a incubação, as placas foram tratadas com uma solução de Vermelho Congo (1 mg/ml - Merck) e incubadas à temperatura ambiente por 15 min. Em seguida, as placas foram lavadas várias vezes com solução esterilizada de $\mathrm{NaCl}$ (Merck) $1 \mathrm{M}$ durante 10-15 min para remover excesso do corante. A formação de um halo de coloração clara na superfície vermelha do 
Tabela 1. Isolados bacterianos utilizados no presente trabalho

\begin{tabular}{|c|c|}
\hline Isolados & Fonte \\
\hline \multirow{2}{*}{$\begin{array}{l}\text { ARB18 } \\
\text { PR1.5/2 }\end{array}$} & Araújo et al. 2002 \\
\hline & ESALQ/USP * \\
\hline TO45 & Araújo et al. 2001 \\
\hline $\mathrm{PR} 2 / 7$ & Araújo et al. 2002 \\
\hline ARB18/10 & ESALQ/USP \\
\hline CL12 & Araújo et al. 2001 \\
\hline CTO2 & Araújo et al. 2001 \\
\hline СТO5 & Araújo et al. 2001 \\
\hline LCO6 & Araújo et al. 2001 \\
\hline LC32 & Araújo et al. 2001 \\
\hline LT37 & Araújo et al. 2001 \\
\hline LV23 & Araújo et al. 2001 \\
\hline LV24 & Araújo et al. 2001 \\
\hline $\mathrm{PR} 1 / 4$ & ESALQ/USP \\
\hline PR1.5/4 & ESALQ/USP \\
\hline PR1.5/9 & ESALQ/USP \\
\hline TC41 & Araújo et al. 2001 \\
\hline TO47 & Araújo et al. 2001 \\
\hline TS49 & Araújo et al. 2001 \\
\hline TS51 & Araújo et al. 2001 \\
\hline C33.2 & ESALQ/USP \\
\hline $\mathrm{C} 32.2$ & ESALQ/USP \\
\hline C35.1 & ESALQ/USP \\
\hline C39.1 & ESALQ/USP \\
\hline $\mathrm{C} 40.1$ & ESALQ/USP \\
\hline C41.1 & ESALQ/USP \\
\hline C45.1 & ESALQ/USP \\
\hline C49.1 & ESALQ/USP \\
\hline C55.1 & ESALQ/USP \\
\hline C56.1 & ESALQ/USP \\
\hline EGE1 & Procópio, 2004 \\
\hline EUE7 & Procópio, 2004 \\
\hline ETE7 & Procópio, 2004 \\
\hline EIE3 & Procópio, 2004 \\
\hline EIE6 & Procópio, 2004 \\
\hline EGE6 & Procópio, 2004 \\
\hline EGE8 & Procópio, 2004 \\
\hline EGS2 & Procópio, 2004 \\
\hline ECE5 & Procópio, 2004 \\
\hline ECE6 & Procópio, 2004 \\
\hline ECE7 & Procópio, 2004 \\
\hline ETE8 & Procópio, 2004 \\
\hline EUE6 & Procópio, 2004 \\
\hline EN80 & Kuklinsky-Sobral et al. 2004 \\
\hline EN192 & Kuklinsky-Sobral et al. 2004 \\
\hline EN103 & Kuklinsky-Sobral et al. 2004 \\
\hline EN179 & Kuklinsky-Sobral et al. 2004 \\
\hline EN306 & ESALQ/USP \\
\hline ENB73 & ESALQ/USP \\
\hline $65 \mathrm{R} 1$ & ESALQ/USP \\
\hline $64 \mathrm{R} 1$ & ESALQ/USP \\
\hline $66 \mathrm{R} 1$ & ESALQ/USP \\
\hline 2B9 & ESALQ/USP \\
\hline
\end{tabular}

*Bactérias da coleção do Laboratório de Genética de Microrganismos "Prof. João Lúcio de Azevedo", ESALQ/USP 
meio indicou a hidrólise de CMC. $\mathrm{O}$ índice de atividade de endoglicanase (IA) foi determinado pela relação entre o diâmetro do halo de degradação de CMC e o diâmetro da colônia bacteriana.

\subsubsection{Extração de DNA genômico}

As linhagens foram cultivadas em $5 \mathrm{ml}$ de LB líquido por 24 horas a $28^{\circ} \mathrm{C}$ sob agitação (150 rpm). Um volume de 2 - $4 \mathrm{ml}$ da cultura foi centrifugado por 5 min a $14.000 \mathrm{~g}$ e as células ressuspendidas em $500 \mu \mathrm{l}$ de TE [(10 mM de Tris$\mathrm{HCl}$ (Sigma); pH 8,0), centrifugadas e ressuspendidas novamente em $500 \mu \mathrm{l}$ de TE com o acréscimo de $0,5 \mathrm{~g}$ de pérolas de vidro de $0,1 \mathrm{~mm}$ de diâmetro (Sigma)] e $15 \mu$ de SDS (Sigma) 20\%. As células foram agitadas em um homogeneizador (Mine-Beadbeater ${ }^{\mathrm{TM}}$, Biospec) por $30 \mathrm{~s}$ a $3.500 \mathrm{bpm}$. Ao lisado celular foram adicionados $500 \mu \mathrm{l}$ de fenol, homogeneizados por inversão e centrifugados por 5 min a $14.000 \mathrm{~g}$. A fase aquosa foi extraída uma vez com fenol-clorofórmio (1:1) e uma vez com clorofórmio. O DNA foi precipitado com $1 / 10$ volume de $\mathrm{NaCl}$ (Merck) $5 \mathrm{M}$ e 0,6 volume de isopropanol (Merck) 3 min à temperatura ambiente e coletado por centrifugação $(10 \min$ a $14.000 \mathrm{~g})$. $\mathrm{O}$ precipitado de DNA foi lavado com etanol (Merck) $70 \%$, seco a $37^{\circ} \mathrm{C}$ e ressuspendido em $50 \mu \mathrm{l}$ de água milli-Q esterilizada. O DNA total foi analisado por eletroforese em gel de agarose (Invitrogen) $(0,8 \%$ p/v) em tampão 1x TAE 
[(40 mM de Tris-acetato (Sigma); 1mM de EDTA (Sigma)] e corado com brometo de etídio (Sigma) (0,5 $\mu \mathrm{g} / \mathrm{ml})$, segundo Sambrook et al. (1989).

\subsubsection{Análise por BOX-PCR}

As reações de BOX-PCR foram realizadas em um volume final de $25 \mu \mathrm{l}$, contendo 5 a $10 \mathrm{ng}$ de DNA; $1 \times 10^{6} \mathrm{pM}$ do primer BOX A1R (5'CTACGGCAAGGCGACGCTGACG-3'); 7,5 mM de $\mathrm{MgCl}_{2}, 1 \mathrm{U}$ da enzima Taq DNA polimerase (Invitrogen); 0,6 mM de cada dATP, dCTP,dGTP, e dTTP. A reação de amplificação foi realizada em termociclador (PTC-200, MJ Research), programado para realizar uma desnaturação inicial de 10 min a $95^{\circ} \mathrm{C}, 30$ ciclos de $1 \mathrm{~min}$ a $95^{\circ} \mathrm{C}, 30$ ciclos de $1 \mathrm{~min}$ a $72^{\circ} \mathrm{C}$. A extensão final foi executada por 10 min a $72^{\circ} \mathrm{C}$. Após a amplificação, $5 \mu$ da reação de PCR foram avaliados por eletroforese em gel de agarose (Invitrogen) (1,5\% p/v) em tampão 1X TAE por 2 h a 100 V. Em seguida, o gel foi corado com brometo de etídio (Sigma) (0,5 $\mu \mathrm{g} / \mathrm{ml}$ ), observado sobre luz ultravioleta e fotografado com auxílio do programa Gel Doc 2000 (Bio-Rad). Um marcador de peso molecular DNA Ladder (IBM Fermentas) foi incluído em cada eletroforese. 


\subsubsection{Análise computadorizada de BOX-PCR}

Amostras de PCR foram submetidas à eletroforese em 1,5\% de gel de agarose (Invitrogen) por $2 \mathrm{~h}$ a $100 \mathrm{~V}$. Em seguida, o gel foi corado com (Sigma) de etídio $(0,5 \mu \mathrm{g} / \mathrm{ml})$ por $15 \mathrm{~min}$, observado sobre luz ultravioleta e fotografado utilizando o sistema Gel Doc 2000 (Bio-Rad). As imagens foram capturadas e salvas diretamente como documentos do tipo TIFF e processadas pelo programa BioNumerics 3.0 (Applied Maths). Matrizes de similaridade de curvas densiométricas foram calculadas utilizando-se o coeficiente de correlação de Jaccard. Análises de agrupamentos de matrizes de similaridade foram realizadas utilizando o algoritmo UPGMA (Unweighted Pair Group Method with Arithmetic mean). A correlação foi expressa como porcentagem de similaridade. A semelhança mínima a um nível de $60 \%$ entre os isolados foi utilizada como o critério para definir uma OTU (Operational Taxonomic Unit), segundo Yang et al. (2004).

\subsubsection{Avaliação do índice de diversidade}

$O$ índice de diversidade de Shannon $\left(H=-\Sigma\left(x_{i} / x_{0}\right) \ln \left(x_{i} / x_{0}\right)\right.$ onde $x_{i}=$ número de isolados em uma OTU e $x_{0}=$ número total de isolados) foi calculado para os isolados bacterianos submetidos aos experimentos de BOX-PCR, para cada planta hospedeira (Davelos-Baines et al., 2005). 


\subsubsection{Análise estatística}

A análise dos dados foi feita com auxílio do programa SAS versão 6.0 (SAS, 1989). O teste $\mathrm{T}$ foi realizado de acordo com o método proposto por Magurran (1988) para detectar diferença entre os índices de diversidade, obtidos a partir dos experimentos de BOX-PCR.

\subsection{Resultados}

\subsubsection{Produção de endoglicanase e sensibilidade a antibiótico}

Para avaliar o potencial de enterobactérias endofíticas como futuros vetores para secretar proteínas ou outras enzimas, a produção de endoglicanase e sensibilidade a antibiótico foram testadas. A mais baixa produção de endoglicanase foi observada entre os isolados de cacau, pois dois entre os dez isolados (20\%) testados produziram esta enzima in vitro. Produção semelhante foi observada para isolados de citros, já que quatro entre os 20 isolados $(20 \%)$ analisados produziram endoglicanase. Para cana-de-açúcar, três entre os 4 isolados (75\%) estudados produziram endoglicanase. A mais alta média de produção de endoglicanase foi observada em isolados de soja (cinco entre os seis testados) e eucalipto (dezesseis entre os dezessete estudados), mostrando 83 e 92\% de produção, respectivamente. Da mesma 
forma, o índice de atividade de endoglicanase (IA) foi mais baixo para os isolados de cacau, seguido por citros. Os isolados de eucalipto, soja e cana-deaçúcar apresentaram os maiores valores de IA (Figura 1). Quanto à sensibilidade aos antibióticos, todos os isolados testados apresentaram sensibilidade à canamicina em ambas as concentrações usadas. Com relação à ampicilina, a sensibilidade foi heterogênea de acordo com a planta hospedeira (Tabela 2), sendo observada uma sensibilidade de 15\% para isolados de citros, 54\% para eucalipto, $67 \%$ para soja e $75 \%$ para cana-de-açúcar (dados não mostrados). No entanto, nenhum isolado de cacau apresentou sensibilidade a este antibiótico (Tabela 2).

\subsubsection{BOX-PCR de enterobactérias endofíticas}

A análise de BOX-PCR foi realizada em 53 bactérias endofíticas da família Enterobacteriaceae isoladas de plantas de cacau, cana-de-açúcar, citros, eucalipto e soja. Curvas baseadas na correlação entre o coeficiente produto-momento foram usadas para a comparação pareada dos perfis observados. Além disso, o algoritmo UPGMA foi usado para realizar o agrupamento de todos os isolados (Figura 2). 


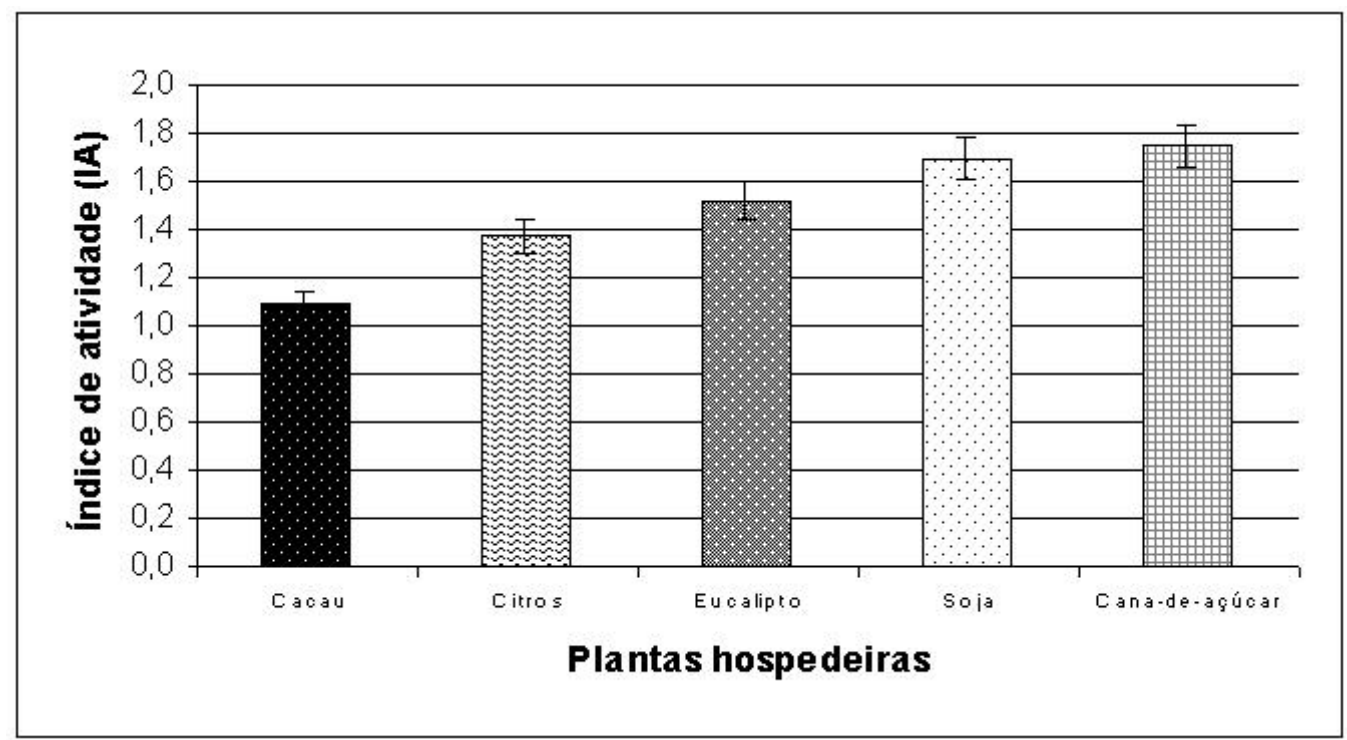

Figura 1 - Índice de atividade de celulase (IA) de isolados de enterobactérias endofíticas de cinco plantas hospedeiras. Os valores de IA de cada hospedeiro representam a média dos isolados produtores 
Tabela 2. Isolados bacterianos utilizados e características relevantes

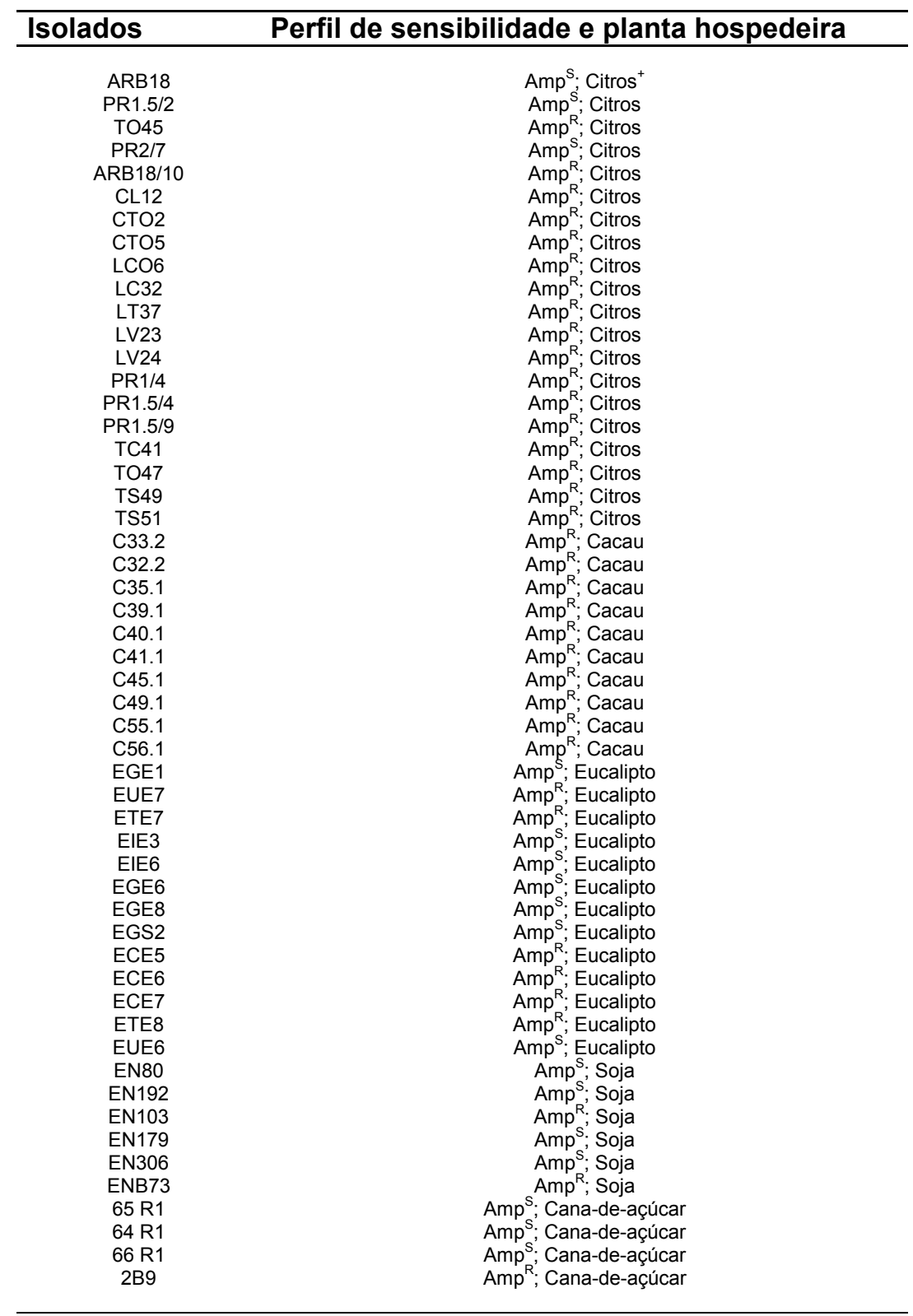

$+A m p^{S}$ e $A m p^{R}$ significam sensibilidade e resistência ao antibiótico ampicilina, respectivamente 

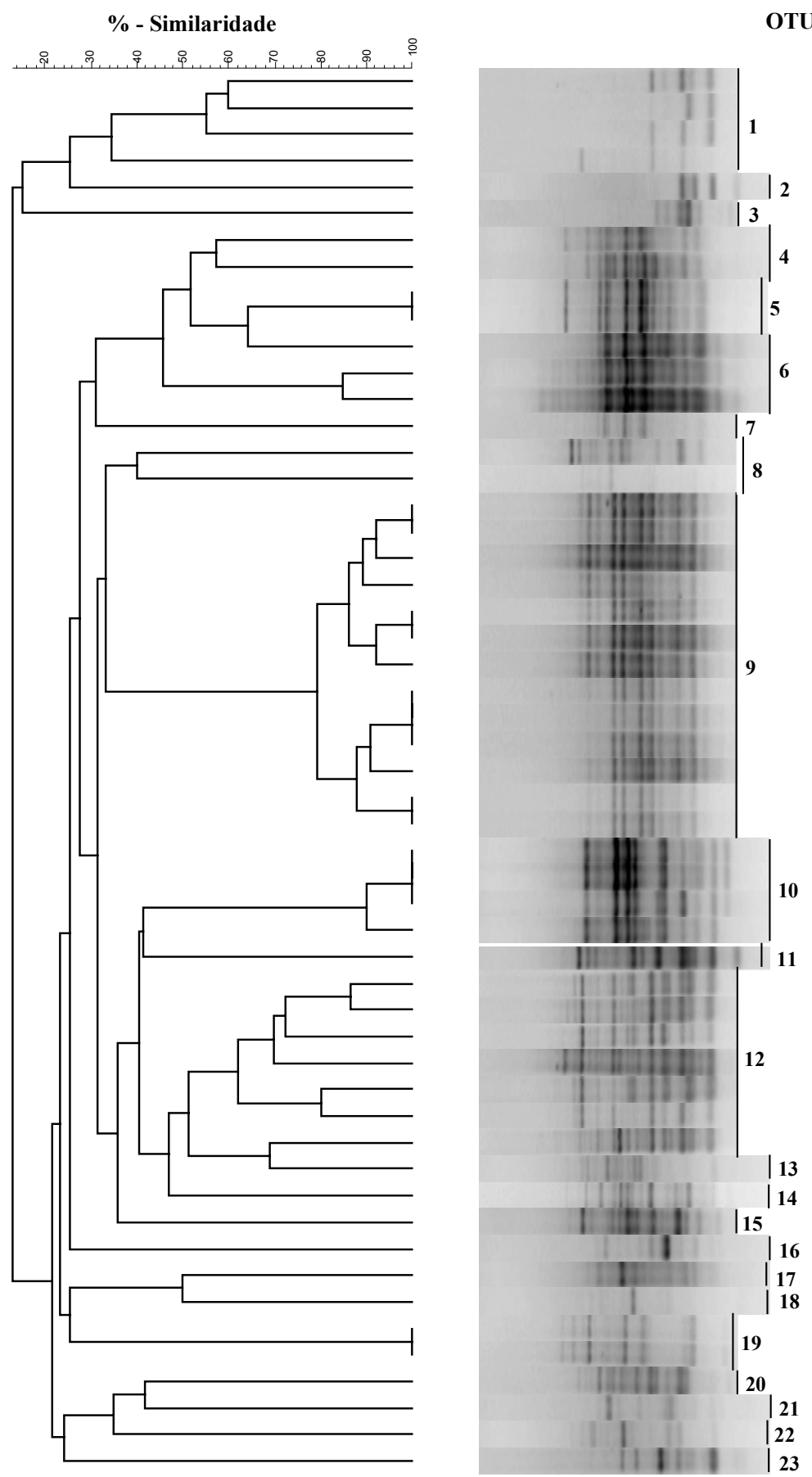

Isolados

\begin{tabular}{|c|c|}
\hline C39.1 & Cacau \\
\hline C40.1 & Cacau \\
\hline C56.1 & Cacau \\
\hline C55.1 & Cacau \\
\hline EN80 & Soja \\
\hline PR1.5/9 & Citros \\
\hline ECE6 & Eucalipto \\
\hline ETE8 & Eucalipto \\
\hline PR1.5/4 & Citros \\
\hline PR1.5/2 & Citros \\
\hline 2B9 & Cana-de-açúcar \\
\hline ECE7 & Eucalipto \\
\hline ETE7 & Eucalipto \\
\hline EUE7 & Eucalipto \\
\hline ECE5 & Eucalipto \\
\hline ENB73 & Soja \\
\hline LCO6 & Citros \\
\hline LV23 & Citros \\
\hline TS49 & Citros \\
\hline TO45 & Citros \\
\hline CL12 & Citros \\
\hline TC41 & Citros \\
\hline TS51 & Citros \\
\hline LT37 & Citros \\
\hline LV24 & Citros \\
\hline TO47 & Citros \\
\hline LD32 & Citros \\
\hline CTO2 & Citros \\
\hline CTO5 & Citros \\
\hline ARB18/10 & Citros \\
\hline ARB18 & Citros \\
\hline EGE8 & Eucalipto \\
\hline EGE1 & Eucalipto \\
\hline EN306 & Soja \\
\hline C 33.2 & Cacau \\
\hline C41.1 & Cacau \\
\hline C 35.1 & Cacau \\
\hline $\mathrm{PR} 2 / 7$ & Citros \\
\hline C49.1 & Cacau \\
\hline C45.1 & Cacau \\
\hline C32.2 & Cacau \\
\hline EGE6 & Eucalipto \\
\hline EIE3 & Eucalipto \\
\hline PR1/4 & Citros \\
\hline EN179 & Soja \\
\hline EGS2 & Eucalipto \\
\hline EUE6 & Eucalipto \\
\hline 66R1 & Cana-de-açúcar \\
\hline $65 \mathrm{R} 1$ & Cana-de-açúcar \\
\hline $64 \mathrm{R} 1$ & Cana-de-açúcar \\
\hline EN103 & Soja \\
\hline EIE6 & Eucalipto \\
\hline EN192 & Soja \\
\hline
\end{tabular}

Figura 2 - Dendrograma de fingerprinting por BOX-PCR de 53 enterobactérias endofíticas isoladas de cacau, cana-de-açúcar, eucalipto e soja. Os agrupamentos foram feitos por UPGMA usando o coeficiente de Jaccard, e estão representados por porcentagem de similaridade 
A partir da análise dos perfis de BOX-PCR, 23 OTUs (sendo nove agrupamentos e quatorze perfis únicos) puderam ser distinguidos utilizando nível de similaridade de $60 \%$. A OTU1 foi formada por somente quatro isolados de cacau, enquanto que a OTU12 agrupou seis isolados de cacau e um de citros. Este isolado foi identificado por Araújo et al. (2002) como sendo a enterobactéria Enterobacter cloacae. A OTU9 foi formada pelo maior número de isolados (treze), sendo que todos são provenientes de plantas de citros. Estes isolados foram previamente identificados por Araújo et al. (2001) como Pantoea agglomerans.

A OTU1, da mesma forma que a OTU10, foi formada por quatro isolados, consistindo de $50 \%$ de citros e $50 \%$ de eucalipto. Referindo-se ainda à OTU10, esta foi representada por apenas dois isolados (ARB18 e EGE1) identificados como P. agglomerans por Araújo et al. (2002) e Procópio (2004), respectivamente.

A OTU6 agrupou três isolados (um de cana-de-açúcar e dois de eucalipto). O isolado de eucalipto ETE pertencente a esta OTU, foi identificado por Procópio (2004) como Hafnia alvei.

As OTUs representadas por apenas dois isolados foram: OTU4 (eucalipto); OTU5 (citros); OTU8 (eucalipto e soja ) e OTU19 (cana-de-açúcar). As demais OTUs: $2,3,7,11,13,14,15,16,17,18,20,21,22$ e 23, foram representadas por um único isolado, pois exibiram perfis únicos de BOX-PCR. 
Procópio (2004) identificou o representante da OTU7 como sendo $P$. ananatis, enquanto que os representantes das OTUs 2, 11, 16, 21 e 23 foram identificados por Kuklinsky-Sobral et al. (2004) como P. agglomerans.

A maioria dos isolados de citros pertenceu à OTU9, porém outros isolados de citros também foram encontrados nas OTUs $3,5,10,12$, e 15. Mais restritamente, os isolados de cacau enquadraram-se apenas nas OTUs 1 e 12.

Os Isolados de eucalipto, soja e cana-de-açúcar foram os que apresentaram maior diversidade genética de acordo com os perfis de BOXPCR. Tais perfis foram formados por poucos isolados agrupados em uma única OTU ou constituíram suas próprias OTUs. Esta observação está de acordo com a análise de diversidade genética, a qual mostrou-se superior para isolados de eucalipto $(2,2)$, soja $(1,8)$, citros e cana-de-açúcar (1,2 e 1,0, respectivamente), sendo que estes dois últimos índices não diferiram estatiscamente. Por sua vez, isolados de cacau apresentaram o menor índice de diversidade $(0,7)$ (Figura 3). 


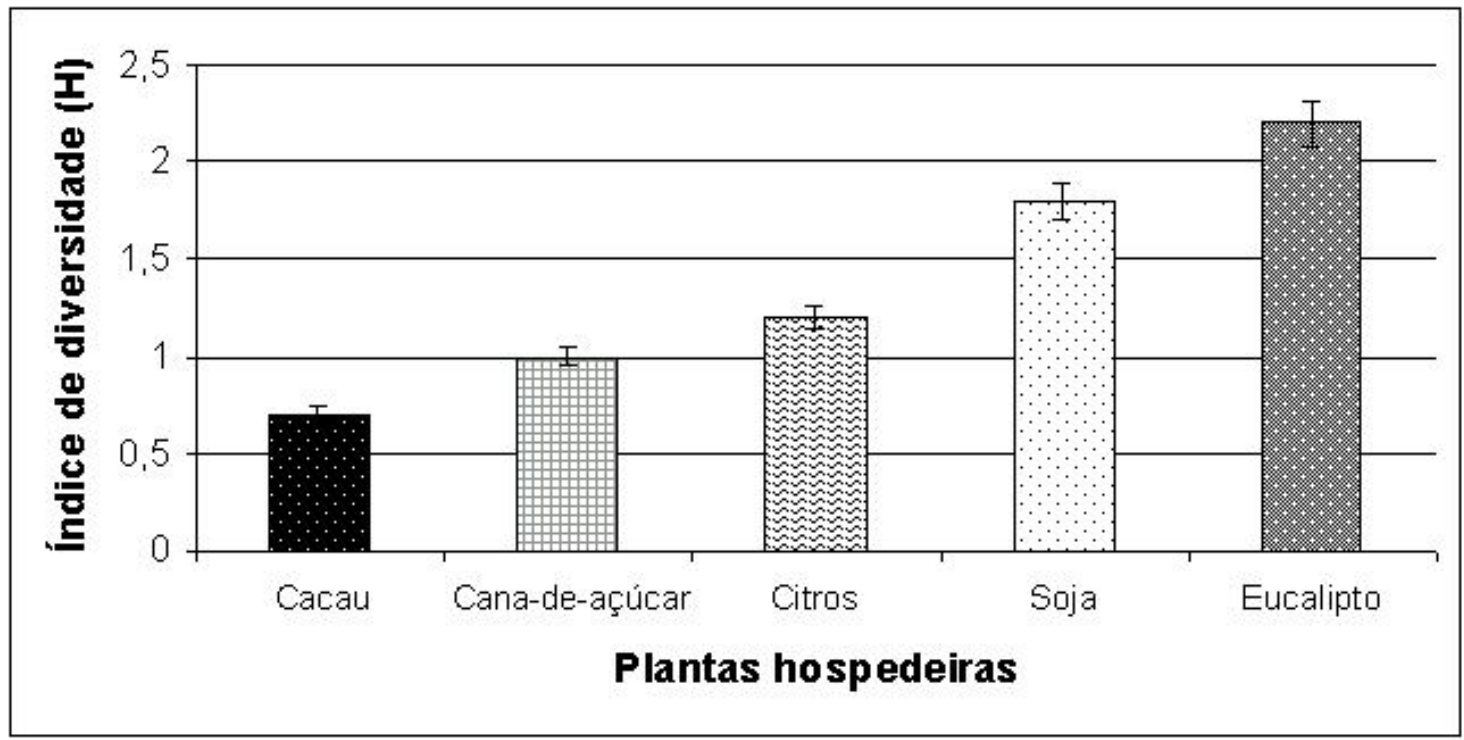

Figura 3 - Diversidade de isolados de enterobactérias endofíticas de cacau, cana-de-açúcar, citros, eucalipto e soja, obtidos nas análises de BOX-PCR, usando o índice de diversidade de Shannon $(H)$ 


\subsection{Discussão}

A compreensão da diversidade microbiana associada a técnicas de DNA recombinante podem representar a base para a utilização dos endófitos, ampliando seu potencial para uso como ferramenta na agricultura. Informações moleculares detalhadas sobre a diversidade podem nos ajudar a entender a evolução da funcionalidade dos microrganismos em seu ambiente natural, criando novas variantes genéticas em níveis inferiores a espécies. A seleção de funções recentemente adquiridas pode nos dar a chave para entender a diversidade funcional de comunidades microbianas, assim como sua função no ecossistema como um todo (Schloter et al. 2000).

Este trabalho teve como objetivos caracterizar enterobactérias endofíticas isoladas de cinco culturas de grande importância econômica no Brasil (cacau, cana-de-açúcar, citros, eucalipto e soja), quanto à sensibilidade a antibióticos e produção celulase (endoglicanase), assim como avaliar a diversidade genética destes isolados utilizando BOX-PCR, uma técnica poderosa para discriminar diversidade bacteriana (Lanoot et al., 2004).

Inicialmente, todos os isolados foram analisados quanto à sensibilidade a antibióticos e também quanto à produção de celulase. Todos os isolados apresentaram sensibilidade à canamicina. Ao contrário, com relação à ampicilina, foi verificada variação na sensibilidade de acordo com a planta hospedeira. A produção de celulase também mudou de acordo com a planta 
hospedeira. Segundo Germaine et al. (2004), a produção de celulase é uma característica possivelmente requerida para que os endófitos colonizem a planta, uma vez que a colonização é um processo ativo e não simplesmente uma difusão passiva de bactérias no espaço intercelular das plantas (Dong et al., 2003).

A técnica de BOX-PCR foi escolhida para avaliar a diversidade dos isolados de enterobactérias endofíticas por ser rápida, barata e de fácil execução, além de ser altamente discriminativa em nível de subespécie (Olive \& Bean, 1999), produzindo resultados semelhantes àqueles obtidos pelas análise de pareamento de DNA-DNA (Rademaker et al., 2000).

Os perfis de BOX-PCR foram analisados por um protocolo baseado em curvas, o qual retém mais informação do que somente o número e posição dos fragmentos no gel (Hane et al., 1993, Yang et al., 2004).

No presente trabalho, a diversidade genética de 53 isolados analisada por BOX-PCR permitiu agrupá-los em 23 diferentes OTUs. Estas OTUs exibiram em sua maioria uma relação não-estrita com seu respectivo hospedeiro vegetal. Esse fato teve uma implicação direta no índices de diversidade de bactérias nos hospedeiros analisados, que foram mais altos para isolados de eucalipto e soja. De acordo com Yang et al. (2004), a presença de 23 OTUs poderia indicar que os 53 isolados compreendem na verdade 23 espécies diferentes, uma vez que, quando a técnica de BOX-PCR é utilizada para estudo da diversidade microbiana, OTUs individuais devem ser definidas 
como espécies em potencial. Contudo, nenhuma definição consistente de OTU é empregada atualmente, levando a estimativas que não podem ser comparáveis entre si. Isolados representativos de sete diferentes OTUs foram previamente identificados por outros autores, usando diferentes técnicas de análise de diversidade (RAPD, ARDRA e seqüenciamento do rDNA 16S). Tais isolados foram identificados como pertencentes à espécie de $P$. agglomerans, com exceção de $P$. ananatis e $H$. alvei. Sugere-se então que a maioria dos OTUs observados neste trabalho consistiu de subespécies de $P$. agglomerans. Esta hipótese é endossada por Yang et al. (2004), os quais sustentam que BOX-PCR é uma técnica de alta resolução genômica para se estimar a diversidade dentro de espécies, o que significa que se trata de uma técnica poderosa para discriminar diversidade de subespécies. Em resumo, no presente estudo, tecnologia de BOX-PCR foi muito bem sucedida para discriminar diversidade genética de bactérias intimamente relacionadas da família Enterobacteriaceae. Finalmente, espera-se que esta pesquisa seja continuada e ampliada com a finalidade de se obter novas informações, melhorando cada vez mais a compreensão da comunidade de enterobactérias endofíticas das importantes culturas de cacau, cana-de-açúcar, citros, eucalipto e soja. 


\subsection{Conclusões}

Os resultados apresentados permitiram concluir que:

a) todos os isolados bacterianos analisados apresentaram sensibilidade ao antibiótico canamicina, porém a sensibilidade à ampicilina variou de acordo com a planta hospedeira;

b) a produção de celulase pelos isolados variou segundo a planta hospedeira;

c) análise da diversidade genética por BOX-PCR agrupou a maioria dos isolados em subespécies de Pantoea agglomerans;

d) os isolados endofíticos de eucalipto e soja apresentaram maior diversidade genética. 


\section{COLONIZAÇÃO DE Catharantus roseus (vinca) POR ENTEROBACTÉRIAS ENDOFÍTICAS EXPRESSANDO O GENE gfp}

\section{Resumo}

Muito pouco é sabido sobre a colonização de bactérias endofíticas da família Enterobacteriaceae em plantas. O presente estudo descreve a introdução e reisolamento de dois isolados de enterobactérias endofíticas expressando os genes de resistência à ampicilina e o gene da proteína verde fluorescente (GFP) em Catharantus roseus (vinca). Além disso, decreve a avaliação do impacto desta introdução na diversidade genética da comunidade natural de vinca. Tal avaliação foi realizada por meio da técnica de análise de restrição do rDNA $16 S$ amplificado (ARDRA), utilizando a enzima de restrição Alul. Este estudo mostrou que os endófitos expressando gfp colonizaram as raízes e caules das plantas inoculadas, sem causar qualquer sintoma de doença durante o período de estudo. Foi observado que a população endofítica expressando gfp caiu drasticamente 20 dias após a inoculação sob seleção por antibiótico. Seis perfis eletroforéticos obtidos por ARDRA foram denominados haplótipos A, B, C, D, E e F. Como conseqüência da introdução de bactérias 
endofíticas, foram observados quatro differentes haplótipos C, D, E e F, os quais não foram observados nas plantas controle. Estes resultados mostraram que os colonizadores endofíticos não levaram à diminuição da diversidade (índice de diversidade de Shannon) da população microbiana natural de vinca.

\section{Summary}

Very little is known about the colonization of bacterial endophytes from Enterobacteriaceae family in plants. This study describes the introduction and re-isolation of two green fluorescent protein ( $g f p)$ :ampicillin ${ }^{R}$ labelled (pPAgfp) enterobacteria endophytes into Catharantus roseus (vinca) and the impact of the endophytes introduction under vinca microbial community diversity was assigned by na analysis of the restriction patterns produced by amplified DNA coding fo $16 \mathrm{~S}$ rRNA (ARDRA) with the enzyme Alul. Throughout the study, the endophytes gfp expressing showed considerable colonization in the roots and stems of inoculated plants. No symptom of disease was noticied in any plant during the experimental period. The bacteria endophytic population expressing gfp gene decrease drastically 20 days after inoculation under antibiotic selection. We observed six different electrophoretic profiles by ARDRA fingerprint, that were called haplotypes A, B, C, D, E and F. As consequence of the endophyte bacteria introduction were observed four different haplotypes C, $D, E$ and $F$, which were not present in the control plants. These results showed 
that the endophytic colonizers do not decreased the diversity (by Shannon diversity index) of the indigenous microbiota of vinca.

\subsection{Introdução}

A colonização bacteriana de tecidos internos de plantas tem sido descrita em quase todas as espécies de vegetais examinadas até o momento. Ainda que muitas dessas bactérias sejam fitopatogênicas, um número considerável tem sido encontrado daquelas que colonizam a planta sem causar doença; tais bactérias são denominadas endofíticas (Sessitsch, et al., 2002). A colonização pode ocorrer em tecidos localizados ou por toda a planta, com colônias bacterianas e os biofilmes residindo de forma latente nos espaços intercelulares e no interior de tecidos vasculares (Sessitsch, et al., 2002; Hinton \& Bacon, 1995). Diversos gêneros bacterianos têm sido isolados do interior de tecidos vegetais (Sturz et al., 1999), embora nenhum estudo tenha sido feito para analisar somente bactérias endofíticas da família Enterobacteriacea.

Sturz et al. (2000) propuseram que os endofíticos se originam da microbiota da rizosfera ou do filoplano e observaram que várias bactérias da rizosfera penetraram e colonizaram o tecido da raiz, dirigindo-se para o xilema. Nesse tecido vascular, as bactérias podiam transportar-se pela planta e assim colonizá-la de forma sistêmica. Tem sido observado que, uma vez dentro da 
planta, a população endofítica é capaz de crescer entre 2,0 e 7,0 $\log _{10}$ células por grama de tecido fresco (Mclnroy \& Kloepper, 1994; Shishido et al., 1999).

Tem sido mostrado que certas bactérias endofíticas também promovem o crescimento de plantas, assim como aumentam a resistência das mesmas ao ataque de patógenos, contra seca e mesmo contra herbivoria. Devido a isso, o seu potencial comercial tem recebido grande atenção. Em particular, tem se observado um especial interesse na possível aplicação comercial de endófitos geneticamente modificados (EGMs). Isto requer um eficiente nível de recolonização de tais bactérias (Germaine et al., 2004). Além disso, é necessário prever o impacto da liberação de EGMs no ambiente natural (Andreote et al., 2004).

Para se avaliar uma colonização eficiente e tamanho da população bacteriana, é necessário localizar e identificar a bactéria inoculada dentro da planta hospedeira. A introdução de genes de resistência a antibióticos em tais bactérias seria então um método simples de se avaliar a colonização. No entanto, as bactérias inoculadas em plantas podem temporariamente perder seu fenótipo de resistência aos antibióticos (Nairn \& Chanway, 2002). Este problema pode ser resolvido ao se aclopar a resistência a antibióticos com genes que expressam a green fluorescent protein (GFP), cujo fenótipo visual é único, bem como um método simples e estável para o estudo da dinâmica da população de organismos no interior dos tecidos vegetais. A GFP é um polipeptídeo de 27 kDa que, quando irradiada com luz negra ou luz UV $\left(A_{395}\right)$, 
produz fluorescência verde $\left(A_{508}\right)$. Este é um marcador útil para estudar microrganismos em ambientes naturais, pois a maioria das bactérias Gramnegativa é capaz de expressar GFP. Além disso, a proteína não requer qualquer substrato exógeno e é extremamente estável.

Os EGMs, em geral, contêm plasmídios recombinantes, e o destino de um plasmídio no ecossistema pode ser monitorado com auxílio de um gene marcador adequado. Portanto, o gene gfp pode ser muito útil nestes casos. (Goris, 2003).

Souza et al. (2000) construíram o plasmídio bifuncional (pPAgfp) de 2,9 $\mathrm{Kb}$ contendo duas origens de replicação, uma de $P$. agglomerans e uma de $E$. coli, além dos genes de resistência à ampicilina e gfp.

Os objetivos do presente trabalho foram (i) transformar dois isolados C33.1 (cacau) e PR2/7 (citros) de enterobactérias endofíticas com o plasmídio pPAgfp; (ii) avaliar a estabilidade in vitro de pPAgfp nestes EGMs; (iii) inocular enterobactérias endofíticas do tipo selvagem e respectivos EGMs em plântulas de Catharantus roseus (vinca); (iv) reisolar estes EGMs e analisar o impacto dos mesmos sobre a população natural de vinca, usando a técnica de. ARDRA.

\subsection{Material e Métodos}

\subsubsection{Isolados bacterianos, plasmídio e condições de cultivo}


Os isolados bacterianos, endófitos geneticamente modificados (EGMs) e plasmídio utilizados neste trabalho estão descritos na Tabela 1. Os isolados foram crescidos em meio LB [Luria Bertani - $10 \mathrm{~g} / \mathrm{l}$ de triptona (Difco); $5 \mathrm{~g} / \mathrm{l}$ extrato de levedura (USB); $10 \mathrm{~g} / \mathrm{l}$ de $\mathrm{NaCl}$ (Merck); $\mathrm{pH} 7,0$ ] por $18 \mathrm{~h}$ a $28^{\circ} \mathrm{C}$ sob agitação (200 rpm). O antibiótico ampicilina (USB) $(100 \mu \mathrm{g} / \mathrm{ml})$ foi adicionado ao meio para manutenção do plasmídio, após transformação com pPAgfp.

Tabela 1. Plasmídio e isolados bacterianos utilizados, e suas características relevantes

Isolado ou plasmídio

Isolados

C33.1

PR2/7

C33.1 (pPAgfp) (=EAgfp)

PR2/7 (pPAgfp) (=ECgfp)

Escherichia coli DH5 $\alpha$ (pPAgfp)

Plasmídio

pPAgfp

$A m p^{R} ;$ GFP

\section{Fonte}

$A m p^{S}, A m p^{R}$ : sensibilidade e resistência à ampicilina, respectivamente; GFP: denota a expressão da proteína fluorescente verde; ESALQ/USP: isolados da coleção de bactérias endofíticas do Laboratório de Genética de Microrganismos "Prof. João Lúcio de Azevedo" ESALQ/USP 


\subsubsection{Extração de DNA genômico}

As linhagens foram cultivadas em $5 \mathrm{ml}$ de LB líquido por 24 horas a $28^{\circ} \mathrm{C}$ sob agitação (150 rpm). Um volume de 2 - $4 \mathrm{ml}$ da cultura foi centrifugado por 5 min a $14.000 \mathrm{~g}$ e as células ressuspendidas em $500 \mu \mathrm{l}$ de TE [(10 mM de Tris$\mathrm{HCl}$; Sigma $\mathrm{pH} 8,0$ ), centrifugadas e ressuspendidas novamente em $500 \mu \mathrm{l}$ de TE com o acréscimo de $0,5 \mathrm{~g}$ de pérolas de vidro de $0,1 \mathrm{~mm}$ de diâmetro (Sigma)] e $15 \mu \mathrm{l}$ de SDS 20\%. As células foram agitadas em um homogeneizador (Mine-Beadbeater ${ }^{\mathrm{TM}}$, Biospec) por $30 \mathrm{~s}$ a 3.500 bpm. Ao lisado celular foram adicionados $500 \mu \mathrm{l}$ de fenol, homogeneizados por inversão e centrifugados por 5 min a $14.000 \mathrm{~g}$. A fase aquosa foi extraída uma vez com fenol-clorofórmio (Sigma) (1:1) e uma vez com clorofórmio (Merck), então, o DNA foi precipitado com 1/10 volume de $\mathrm{NaCl} 5 \mathrm{M}$ (Merck) e 0,6 volume de isopropanol (Merck) (3 min à temperatura ambiente) e coletado por centrifugação (10 min a $14.000 \mathrm{~g}$ ). O precipitado de DNA foi lavado com etanol $70 \%$, seco a $37^{\circ} \mathrm{C}$ e ressuspendido em $50 \mu \mathrm{l}$ de água milli-Q esterilizada. $\mathrm{O}$ DNA total foi analisado por eletroforese em gel de agarose (Invitrogen) $(0,8 \%$ p/v) em tampão 1x TAE [(40 mM de Tris-acetato (Sigma); 1 mM de EDTA (Sigma)] e corado com brometo de etídio(Sigma) $(0,5 \mu \mathrm{g} / \mathrm{ml})$, segundo Sambrook et al. (1989). 


\subsubsection{Extração de DNA plasmidial}

O DNA plasmidial foi extraído utilizando o Plasmid Midi kit (Qiagen) a partir de células cultivadas em $250 \mathrm{ml}$ de meio LB por $24 \mathrm{~h}$ a $28^{\circ} \mathrm{C}$, de acordo com recomendações do fabricante.

\subsubsection{Transformação de enterobactérias endofíticas}

Células eletrocompetentes de Enterobacter agglomerans C33.1 e Enterobacter cloacae PR2/7 foram obtidas da seguinte forma: as células foram crescidas em meio LB por $18 \mathrm{~h}$ a $28^{\circ} \mathrm{C}$, diluídas em meio LB (1:50) e monitoradas por espectrofotometria até que atingissem $\mathrm{OD}_{600}=0,4$ to 0,7 . Tais células foram centrifugadas $(10.000 \mathrm{~g})$ por $10 \mathrm{~min}$ a $4^{\circ} \mathrm{C}$ e lavadas três vezes com água gelada esterilizada (mili Q). A suspensão de células foi concentrada 50x em glicerol (Merk) 10\% gelado e esterilizado. Em seguida, as células foram aliquotadas e mantidas a $-80^{\circ} \mathrm{C}$. Para transformação bacteriana, $60 \mu \mathrm{l}$ de células eletrocompetentes foram misturados com solução de DNA (100 ng/ $\mu$ ) em uma cubeta de 0,1 cm (Bio-Rad). A eletroporação foi realizada usando o Gene Pulser (Bio-Rad) com os seguintes parâmetros: voltagem 2,5 kV; corrente 25 mA; capacitância de $25 \mu \mathrm{F}$ e resistência de $200 \Omega$, resultando em um tempo constante que variou entre 4 - 6 ms. Imediatamente após o pulso, $1 \mathrm{ml}$ de meio LB foi adicionado à cubeta. A suspensão de células foi transferida para um tubo 
de $1,5 \mathrm{ml}$, e mantido sob agitação $(150 \mathrm{rpm})$ por $1 \mathrm{~h}$ a $28^{\circ} \mathrm{C}$. Bactérias transformadas foram selecionadas em meio LB sólido suplementado com ampicilina (USB) $(100 \mu \mathrm{g} / \mathrm{ml})$.

\subsubsection{Teste da estabilidade do plasmídio in vitro}

A estabilidade do plasmídio pPAgfp nas linhagens transformadas (ECgfp e Eagfp) foi avaliada da seguinte forma: EGMs foram crescidos em meio LB suplementado com ampicilina $(100 \mu \mathrm{g} / \mathrm{ml})$ por $18 \mathrm{~h}$ e diluídos a $10^{3} \mathrm{UFC} / \mathrm{ml}$ em $50 \mathrm{ml}$ de LB sem antibiótico. ECgfp e EAgfp foram crescidos por aproximadamente 36 gerações (duas vezes). Convém informar que, de acordo com experimentos prévios, $40 \mathrm{~min}$ foi o tempo médio de geração das enterobactérias em questão, ou seja o tempo necessário para que estas aumentem um ciclo log ou se dupliquem. As células $\left(10^{3} \mathrm{UFC} / \mathrm{ml}\right)$ da $36^{\mathrm{a}}$ geração foram crescidas por mais 36 gerações. Uma fração das culturas foi então usada para diluições seriadas. Alíquotas foram semeadas em placas contendo meio LB sem ampicilina, o antibiótico requerido para a seleção do plasmídio. Com auxílio de palito, 100 colônias escolhidas aleatoriamente foram inoculadas em LB ágar suplementado com ampicilina e incubadas por $24 \mathrm{~h}$ a $28^{\circ} \mathrm{C}$. As colônias foram então contadas e a porcentagem de EGMs contendo pPAgfp foi calculada. 


\subsubsection{Detecção da expressão do gene gfp em enterobactérias endofíticas}

A expressão heteróloga do gene gfp pelas bactérias contendo pPAgfp foi analisada após $24 \mathrm{~h}$ de incubação a $28^{\circ} \mathrm{C}$, em meio LB suplementado com ampicilina $(100 \mu \mathrm{g} / \mathrm{ml})$. Os EGMs expressando gfp e resistentes a ampicilina (100 $\mu \mathrm{g} / \mathrm{ml}$ ) foram observados sobre transluminador de luz ultravioleta (Fotodyne). a $300-360 \mathrm{~nm}$.

\subsubsection{Experimentos em casa de vegetação}

Os testes em casa de vegetação foram realizados em plântulas de Catharantus roseus (vinca), uma planta modelo utilizada para experimentos in planta (Monteiro et al. 2001), 30 dias após sua semeadura. As plântulas foram acondicionadas em vasos, que permaneceram sob condições de casa de vegetação. O experimento usado consistiu de delineamento inteiramente ao acaso, com 14 repetições, com vasos individuais para cada tratamento e controle constituído de plantas não-inoculadas. Tratamentos consistiram de plantas inoculadas com E. agglomerans C33.1 (Tratamento I); E. cloacae PR2/7 (II); EAgfp (III), ECgfp (IV). As raízes das plantas foram lavadas em água corrente para a retirada do solo agregado às mesmas. Em seguida, as plântulas foram colocadas em uma suspensão bacteriana $\left(10^{9} \mathrm{UFC} / \mathrm{ml}\right)$ em tampão PBS 
(8 $\mathrm{g} / \mathrm{l}$ de $\mathrm{NaCl}$ (Merck), 0,2 $\mathrm{g} / \mathrm{l}$ de $\mathrm{KCl}$ (Merck), 1,4 $\mathrm{g} / \mathrm{l}$ de $\mathrm{Na}_{2} \mathrm{HPO}_{4}$ (Merck) e $0,24 \mathrm{~g} / \mathrm{l}$ de $\mathrm{KH}_{2} \mathrm{PO}_{4}$ (Merck). Após serem colocadas na suspensão de bactérias, as raízes tiveram 1/4 de suas extremidades cortado com auxílio de lâmina de bisturi esterilizada. As plântulas foram deixadas por uma hora em contato com a suspensão bacteriana, para então serem transplantadas para vasos contendo substrato para o crescimento das mesmas. As plantas foram mantidas em casa de vegetação por 20 dias, a uma temperatura média de $28^{\circ} \mathrm{C}$.

\subsubsection{Reisolamento de EGMs}

Os experimentos de reisolamento de enterobactérias endofíticas de caule e raiz de $C$. roseus (vinca) foram feitos 10 e 20 dias após a inoculação. As plantas de vinca foram removidas do solo, suas raízes foram lavadas em água corrente para retirada de solo agregado às mesmas. Em seguida, as plantas foram envoltas em papel toalha e transportadas imediatamente para 0 laboratório, onde foram e separadas em caule e raiz. Caules e raízes foram também separados por tamanho e aparência da superfície para excluir amostras com alguma injúria ou tamanho reduzido.

As bactérias endofíticas foram isoladas por meio de desinfecção superficial dos tecidos, que consistiu nas seguintes etapas: lavagem por $1 \mathrm{~min}$ em etanol (Merck) 70\%; 2 min em hipoclorito de sódio (NaOCl) (Trikem) a 2\% de cloro ativo (v/v) e 30 seg em etanol $70 \%$, seguido de duas lavagens em água 
destilada esterilizada. Os tecidos foram cortados assepticamente, em pequenos fragmentos com o auxílio de bisturi. Em seguida, todo o material foi transferido para tubos de $15 \mathrm{ml}$, contendo $1 \mathrm{ml}$ de tampão PBS (para fragmentos de caule) e $2 \mathrm{ml}$ do mesmo tampão para fragmentos de raiz. Os tubos foram incubados sob agitação (100 rpm) a $28^{\circ} \mathrm{C}$ por $1 \mathrm{~h}$ e $30 \mathrm{~min}$. Diluições apropriadas em tampão PBS foram semeadas em TSA (Merck) $5 \%$ suplementado com o fungicida Benlate (Du Pont) $(100 \mu \mathrm{g} / \mathrm{ml})$.

Foram utilizadas 3 plantas de cada tratamento e 4 placas de Petri por tecido vegetal. As placas foram incubadas a $28^{\circ} \mathrm{C}$ e avaliadas com 2 , 8 e 15 dias de crescimento. Alíquotas da água destilada utilizada na última lavagem foram semeadas em TSA 5\% suplementado com o fungicida Benlate (100 $\mu \mathrm{g} / \mathrm{ml}$ ), incubadas a $28^{\circ} \mathrm{C}$ por $4-15$ dias para confirmar se o processo de desinfecção foi bem sucedido. Amostras também foram semeadas em meio TSA $5 \%$ suplementado com $100 \mu \mathrm{g} / \mathrm{ml}$ de ampicilina para selecionar bactérias expressando o gene gfp.

A população bacteriana por grama de tecido vegetal fresco (UFC/g TVF) foi estimada pela contagem de colônias cultivadas em meio TSA 5\%. Colônias características de cada tipo morfológico foram repicadas e selecionadas para estocagem. 


\subsubsection{Amplificação do rDNA 16S}

A amplificação do rDNA $16 S$ foi realizada por meio da técnica de PCR direto de colônia, de acordo com Gussow \& Clackson (1989), com modificações. Foram escolhidas aleatoriamente de uma a sete colônias de cada tratamento (expressando ou não o gene $g f p$ ) isoladas de vinca, para serem submetidas a PCR do rDNA 16S. Foram utilizados os primers universais para bactérias P027F (5'-GAGAGTTTGATCCTGGCTCAG-3') e 1378R (5'CGGTGTGTACAAGGCCCGGGAACG-3'), que são específicos para o gene do rRNA 16S. As reações apresentaram um volume final de $50 \mu \mathrm{l}$, contendo 5 a 10 ng de DNA molde; $0,2 \mu \mathrm{M}$ de cada primer; $0,2 \mathrm{mM}$ de cada dNTPs; $3,75 \mathrm{mM}$ de $\mathrm{MgCl}_{2}$ e 0,5 U da enzima Taq DNA polimerase em $20 \mathrm{mM}$ de Tris- $\mathrm{HCl}$ pH 8,4 e $50 \mathrm{mM} \mathrm{KCl}$, todos pertencentes à marca Invitrogen. Em todas as reações foi utilizado um controle negativo sem o DNA molde.

A reação de amplificação foi realizada em termociclador (Perkin-Elmer GeneAmp® PCR System 9700) programado para realizar uma desnaturação inicial a $94^{\circ} \mathrm{C}$ por 4 min, 25 ciclos de desnaturação a $94^{\circ} \mathrm{C}$ por $30 \mathrm{~s}$, anelamento a $63^{\circ} \mathrm{C}$ por 1 min e extensão de primers a $72^{\circ} \mathrm{C}$ por 1 min, seguida de extensão final a $72^{\circ} \mathrm{C}$ por 7 min. Após a amplificação, $5 \mu \mathrm{l}$ da reação de PCR foram avaliados por eletroforese em gel de agarose (Invitrogen) (1,2\% p/v) em tampão 
1x TAE e corado com brometo de etídio (Sigma) $(0,5 \mu \mathrm{g} / \mathrm{ml})$, para visualização de um fragmento de aproximadamente $1.350 \mathrm{pb}$.

\subsubsection{Procedimentos de ARDRA}

O impacto da inoculação de enterobactérias endofíticas sobre a população de bactérias endofíticas de vinca foi avaliada usando a técnica de ARDRA (Amplified Ribosomal DNA Restriction Analysis). Para isso, $1 \mu \mathrm{g}$ do fragmento de $16 \mathrm{~S}$ rDNA amplificado foi digerido com a enzima de restrição Alul, de acordo com recomendações do fabricante (IBM Fermentas). Após a digestão, toda a reação foi analisada por eletroforese em gel de agarose $(2,5 \%$ p/v) (Invitrogen) em tampão 1x TAE por $4 \mathrm{~h}$ a $80 \mathrm{~V}$, juntamente com o marcador de peso molecular DNA Ladder 100 pb (IBM Fermentas). Em seguida, o gel foi corado com brometo de etídio (Sigma) $(0,5 \mu \mathrm{g} / \mathrm{ml})$ por $15 \mathrm{~min}$, observado sobre luz ultravioleta e fotografado utilizando o sistema Gel Doc 2000 (Bio-Rad).

\subsubsection{Avaliação do índice de diversidade}

A diversidade bacteriana de vinca foi calculada usando o índice de diversidade de Shannon $(\mathrm{H})$. Para a execução dos cálculos, a seguinte equação modificada de Magurran (1988) foi usada para cada tratamento: $(\mathrm{H}=$ - 
$\Sigma\left(x_{i} / x_{0}\right) \ln \left(x_{i} / x_{0}\right)$ onde $x_{i}=$ número de indivíduos em um grupo $)$ e $x_{0}=$ número total de indivíduos).

\subsubsection{Análise estatística}

A análise estatística foi feita com auxílio do programa SAS versão 6.0 (SAS, 1989) A ANOVA foi analisada com delineamento experimental inteiramente casualizado, a qual testou hipóteses a 5\% de significância (Steel \& Torrie, 1980). Os valores de UFC/g TVF foram transformados usando $\log _{10}$ de X+1 antes da análise da variância. O teste de Tukey foi usado para comparação entre as médias. O teste $\mathrm{T}$ foi realizado de acordo com o método proposto por Magurran (1988) para detectar diferença entre os índices de diversidade, obtidos para cada tratamento, segundo os experimentos de ARDRA.

\subsection{Resultados}

\subsubsection{Transformação de enterobactéria endofítica e estabilidade de pPAgfp in vitro}

Os experimentos de transformação utilizando linhagens de Enterobacter como recipiente foram feitos usando o plasmídio pPAgfp, conforme descrito em material e métodos. No primeiro passo dos experimentos de tranformação, o 
DNA do plasmídio foi obtido da linhagem de E. coli $\mathrm{DH} 5 \alpha$ e inserido por eletroporação no isolado selvagem C33.1 (E. agglomerans). Foram obtidos mais de $2 \times 10^{4}$ transformantes/ $\mu$ g de DNA (agora chamados de Eagfp), indicando que o plasmídio pPAgfp foi transferido para E. agglomerans C33.1 com alta eficiência. Em seguida, no segundo passo dos experimentos de transformação, o DNA do plasmídio obtido de $E$. coli $\mathrm{DH} 5 \alpha$ foi transferido para o isolado PR2/7 (E. cloacae), agora chamado ECgfp. Mais de $4 \times 10^{3}$ transformantes/ $\mu$ g de DNA foram obtidos, indicando que pPAgfp foi transferido para E. cloacae PR2/7 também com eficiência considerável.

As análises de um grupo de transformantes escolhidos ao acaso, revelou que o plasmídio pPAgfp foi mantido estável nas linhagens ECgfp e Eagfp após 36 gerações, sem pressão de seleção por antibiótico. Foram obtidos valores de $100 \%$ de estabilidade para ECgfp e $99,5 \%$ para Eagfp. Isto significa que $100 \%$ e 99,5\% das colônias analisadas apresentaram resistência à ampicilina e expressaram o gene gfp. Da mesma forma, os transformantes EAgfp e ECgfp revelaram que o plasmídio pPAgfp também foi mantido estável mesmo após transcorridas 72 gerações, na ausência de pressão de seleção por antibiótico. Os valores obtidos foram $99,5 \%$ e $98,5 \%$ de estabilidade, respectivamente 


\subsubsection{Reisolamento de EGMs}

A colonização de enterobactérias endofíticas em plantas de vinca foi avaliada em dois períodos após inoculação dos isolados selvagens: C33.1 e PR2/7 e EGMs: ECgfp e Eagfp; e por comparação com as plantas nãoinoculadas. Nenhum sintoma de doença foi observado nas plantas durante o período experimental (Figura 1). Para garantir que o número de bactérias endofíticas isoladas representava somente as células do interior dos tecidos da planta, um procedimento controle foi efetuado para confirmar se a esterilização superficial dos tecidos foi bem sucedida. Sendo assim, durante os experimentos, nenhum crescimento bacteriano foi observado nas placas controle da desinfecção superficial, mostrando que a metodologia utilizada eliminou a comunidade epifítica cultivável dos tecidos vegetais.

Foram observados poucos tipos morfológicos nos endófitos isolados de vinca (Figura $2 \mathrm{~A}$ ), isso sugere uma baixa diversidade da população cultivável isolada em placa. Esse observação foi confirmada pela análise da diversidade derivada dos experimentos de ARDRA.

Foi possível isolar EGMs expressando o gene gfp in vitro (Figura 2B e 2C). Além disso, foram observadas por microscopia de fluorescência, bactérias 

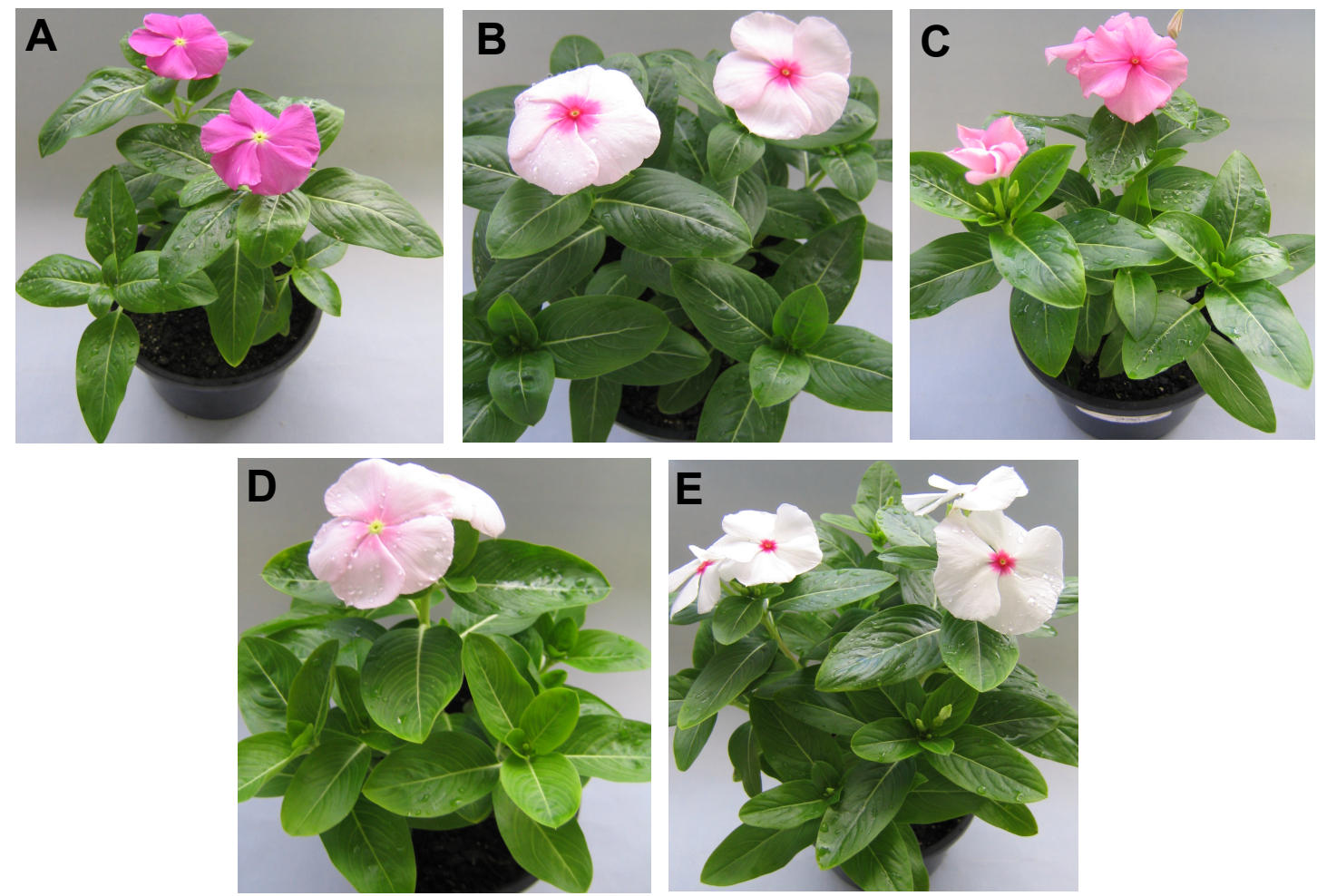

Figura 1 - Plantas de vinca 30 dias após a inoculação de enterobactérias endofíticas. Nota-se ausência de qualquer sintoma de doença nas mesmas. A) Trat. I, B), Trat. II, C), Trat. III, D) Trat IV, E) Planta do controle
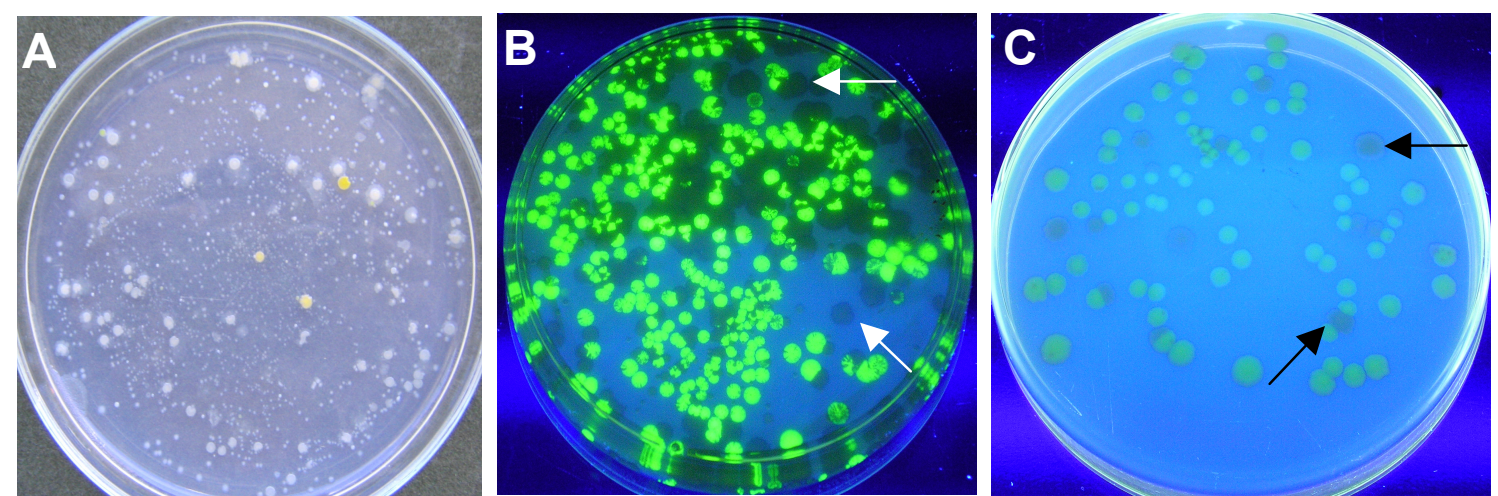

Figura 2 - Bactérias endofíticas isoladas de vinca 10 dias após a inoculação. A) Alguns tipos morfológicos observados; B) Bactérias expressando gfp, isoladas de plantas do Trat. III; C) Bactérias expressando gfp, isoladas de plantas do Trat. IV. Algumas colônias não expressaram gfp (setas) 
expressando o gene gfp no interior de tecidos de raiz de vinca, 10 dias após a inoculação (dados não mostrados).

A densidade total da comunidade bacteriana endofítica variou em torno de $10^{2}$ a $10^{6} \mathrm{UFC/g}$ TVF, na ausência de pressão de seleção por ampicilina. Porém, esta densidade variou com o tipo de tecido analisado, pois a densidade populacional foi maior em raiz do que em caule. Além disso, conforme observado na Figura 3A, a densidade bacteriana total foi maior na ausência de pressão de seleção, (tratamentos I a IV). A população bacteriana expresssando o gene gfp (Figura 3B) diminuiu drasticamente após 20 dias em ambos os tratamentos inoculados com Eagfp (trat. III) e ECgfp (trat. IV) sob pressão de seleção (Figura 3B). Tal população diferiu consideravelmente entre 10 e 20 dias após a inoculação, nos tratamentos com EAgfp e ECgfp, tanto em caule quanto em raiz $(P<0,05)$.

\subsubsection{Efeito da inoculação de EGMs endofíticos sobre a população endofítica natural de vinca}

O impacto da inoculação de enterobactéria endofítica sobre a população natural de vinca foi avaliado usando a técnica de ARDRA. Um total de uma a sete colônias de bactérias isoladas de vinca (expressando ou não o gene gfp) foram escolhidas aleatoriamente de cada tratamento para serem analisadas por ARDRA, usando a enzima Alul. Foram observados seis perfis eletroforéticos 

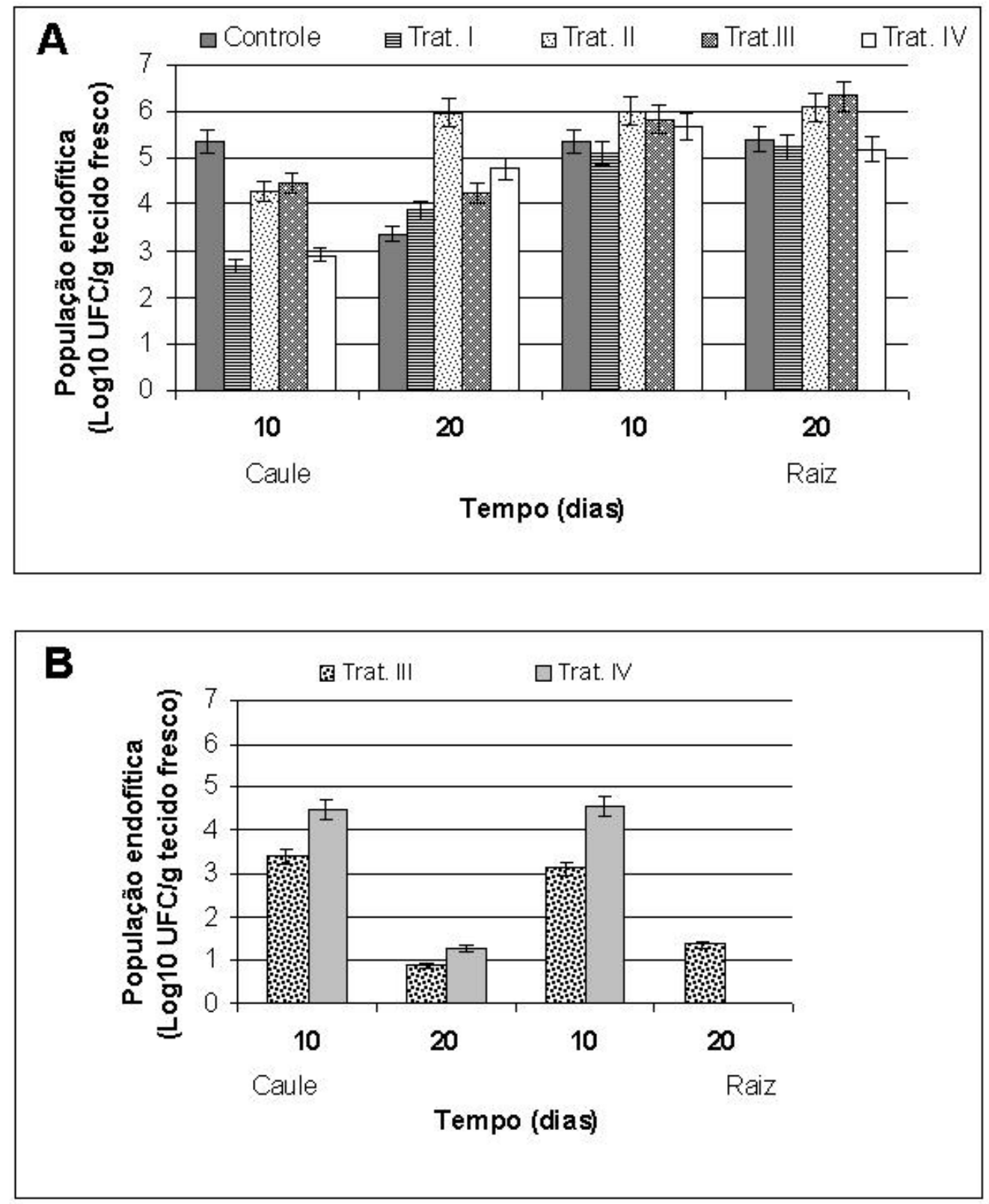

Figura 3 - Número de bactérias (UFC/g de tecido fresco) reisoladas do interior de caule e raiz de plantas de vinca, 10 e 20 dias após a inoculação de enterobactérias endofíticas. (A) Colônias reisoladas em meio TSA na ausência de antibiótico. (B) Enumeração de colônias resistentes à ampicilina, expressando gfp. Os dados representam a média das repetições. As barras indicam o desvio padrão das médias resultantes da avaliação de 3 plantas 
resultantes da digestão com Alul, que foram chamados de haplótipos $A, B, C$, D, E e F. O haplótipo A contou com o maior número de representantes (20), enquanto o haplótipo $E$ compreendeu cinco representantes, e o haplotipo $F$ contou com dois representantes. Os haplótipos B, C e D contaram com apenas um representante cada. Perfis idênticos ao do haplótipo A foram encontrados em todos os tratamentos. Ao contrário, o haplótipo B foi encontrado exclusivamente no controle, enquanto que os haplótipos $C$ e $D$ foram detectados somente no tratamento cujas plantas foram inoculadas com o isolado C33.1.

Como conseqüência da introdução de enterobactérias endofíticas em vinca, foram observados quatro haplótipos diferentes (C, D, E e F), os quais não foram observados no controle. Tais dados estão de acordo com a diversidade genética observada nos experimentos de ARDRA. Segundo os cálculos de diversidade usando o índice de Shannon, foi observada maior diversidade entre os isolados do tratamento III e tratamento I seguidos do tratamento II, controle e tratamento IV (Figura 4). 


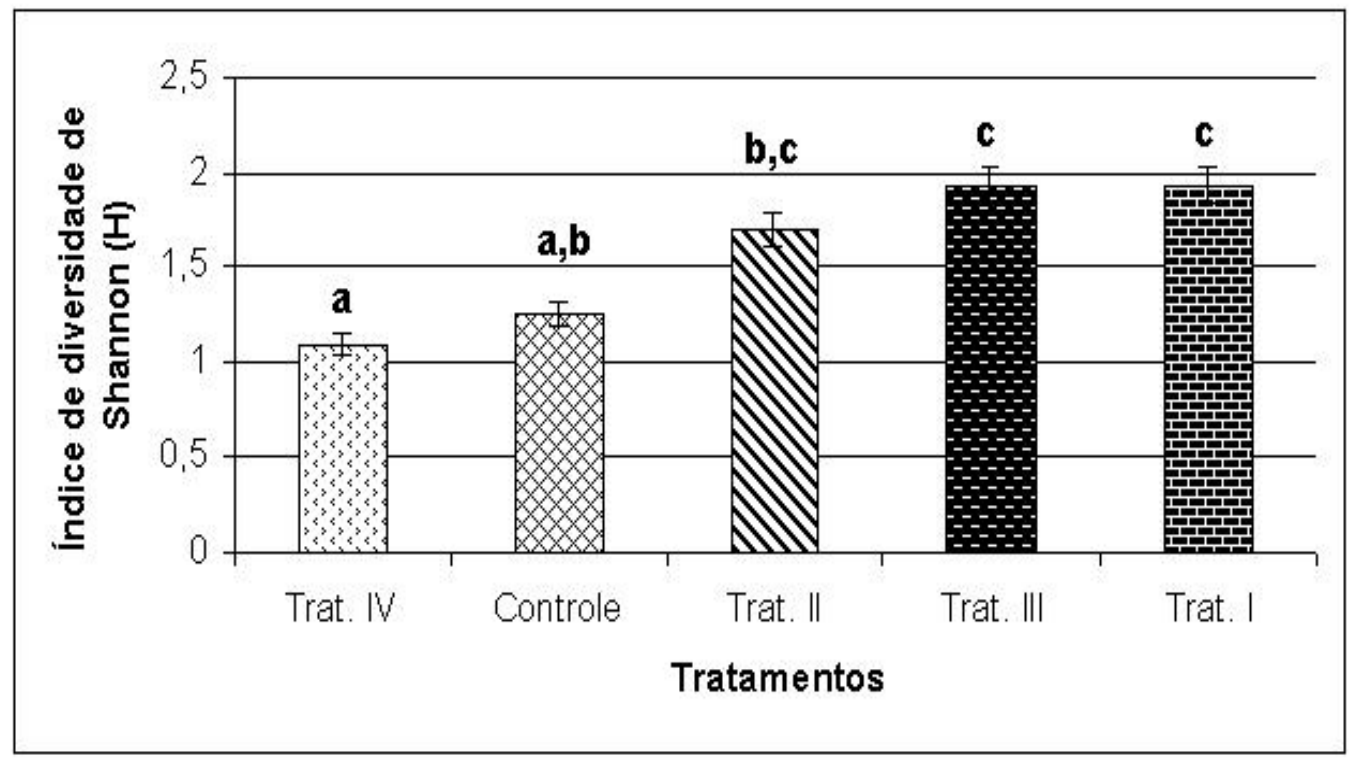

Figura 4 - Índices de diversidade $(\mathrm{H})$ de bactérias endofíticas isoladas de plantas de vinca, nos diferentes tratamentos, obtidos a partir dos experimentos de ARDRA. Barras com a mesma letra não são significativamente diferentes pelo teste $t(P>0,05)$ 


\subsection{Discussão}

A compreensão da diversidade microbiana pode representar a base para a utilização de microrganismos endofíticos geneticamente modificados (EGMs) como inoculantes, uma vez que seu estabelecimento na planta depende de sua habilidade em colonizar e competir com a comunidade microbiana natural (Kloepper \& Beauchamp, 1992). Além disso, qualquer utilização de microrganismos na agricultura requer uma avaliação dos riscos ambientais associados com a introdução de microrganismos naturais ou não dentro da planta (Jackman et al. 1992).

A expressão do gene gfp pode ser uma ferramenta útil no monitoramento de endófitos (Newman \& Reynolds, 2005). Este gene marcador tem sido muito útil em estudos de colonização e na visualização dos eventos de infecção e nodulação de raiz, tanto em Rhizobium spp. quanto em Agrobacterium tumefasciens (Gage et al., 1996; Li et al., 1999; Stuurman et al., 2000). Elbeltagy et al. (2001) mostraram o sucesso da colonização de caule de plantas de arroz por uma versão marcada com gfp do fixador de nitrogênio Herbaspirillum, enquanto que Ramos et al. (2000) usaram gfp para avaliar o estado fisiológico de células de Pseudomonas putida na rizosfera de sementes de cevada. Dessa forma, no presente trabalho ambos os isolados E. cloacae PR2/7 e E. agglomerans C33.1 foram transformados eficientemente com o plasmídio pPAgfp, e passaram a ser chamados ECgfp e Eagfp, 
respectivamente. A eficiência de transformação foi maior para $E$. agglomerans C33.1 do que para E. cloacae PR2/7. Resultados similares foram obtidos por Quecine (comunicação pessoal), que transformou estas mesmas linhagens com o plasmídio pNKBOR. O plasmídio pPAgfp foi mantido estável in vitro, tanto em EAgfp quanto em ECgfp, por pelo menos 72 gerações, sem seleção por antibiótico. Isto sugere que pPAgfp não apresentou qualquer problema que comprometesse sua herança e estabilidade.

Foi constatado que EAgfp e ECgfp colonizaram vinca após sua inoculação. A densidade de bactérias endofíticas foi maior em raiz do que em caule, na ausência de seleção por antibiótico. Estes dados estão de acordo com trabalho feito por Kuklinsky-Sobral et al. (2004) com população bacteriana endofítica de soja, que diminuiu no sentido raiz>caule>folha. Além disso, linhagens de enterobactérias podem diferir muito em sua habilidade de invadir o interior da planta e colonizar as raízes (Dong et al., 2003).

A densidade total de bactérias endofíticas foi maior na ausência de seleção por antibiótico, indicando que a maioria da população natural cultivável de vinca é sensível à ampicilina. A expressão do gene gfp pelas bactérias endofíticas caiu drasticamente após 720 gerações (20 dias). Tal observação foi mais evidente para o tratamento cujas plantas foram inoculadas com ECgfp, no qual nenhuma colônia foi observada expressando gfp, pelo menos em raiz. Convém ressaltar que foram observadas por microscopia eletrônica bactérias expressando o gene gfp em raiz de vinca, dez dias após a inoculação. Isto 
sugere que o plasmídio pPAgfp foi mantido estável in planta por pelo menos 360 gerações. A sobrevivência dos EGMs por até 20 dias após a inoculação sugere que eles são bons colonizadores, e sua rápida distribuição pela planta indica que eles utilizam o sistema vascular como rota para colonizar a planta.

Foi usada a técnica de ARDRA com a enzima de restrição Alul para avaliar o impacto dos EGMs sobre a diversidade da população natural de vinca. Tal técnica tem sido muito utilizada para avaliar diversidade genética de populações naturais (di Cello et al., 1997; Mocali et al., 2003; Michaud et al., 2004). Uma alteração na diversidade genética da população natural de vinca foi demonstrada após a introdução de enterobactérias endofíticas, uma vez que esta diversidade foi igual ou superior a observada nas plantas controle. Dessa forma, pôde-se demonstrar que a diversidade genética da população natural de vinca não decaiu após a introdução de enterobactérias endofíticas ou de EGMs

Em resumo, os resultados mostraram que os EGMs (ECgfp e Eagfp) foram capazes de colonizar o interior de tecidos de vinca, estabelecendo-se em uma densidade alta dentro da planta, além de expressarem o gene gfp. Isto sugere que tais endófitos são bons colonizadores e bons competidores. Além disso, os resultados indicaram que tecidos de vinca proporcionaram um ambiente favorável à proliferação bacteriana e à expressão de gfp, sob condições controladas. Nenhum dos isolados endofíticos inoculados em vinca provocou qualquer sintoma de doença na planta. Assim, tais bactérias poderão ser utilizadas no futuro como vetores para secretar enzimas ou outras 
proteínas, uma vez que a manipulação genética de bactérias endofíticas é mais fácil do que a manipulação genética de plantas. Segundo Newman \& Reynolds (2005), se as bactérias selecionadas forem capazes de colonizar múltiplos hospedeiros, como parece ser o caso dos isolados Eagfp (cacau) e ECgfp (citros), somente poucos tipos de bactérias precisariam ser obtidos para sua utilização como vetor. Contudo, são necessários estudos em condições de campo para se adquirir mais conhecimento sobre o processo de colonização e dinâmica destes EGMs em outras plantas.

\subsection{Conclusões}

Os resultados apresentados permitiram concluir que, pelo menos com o material biológico e condições usadas:

a) endófitos podem ser transformados eficientemente e os vetores se mantêm estáveis in vitro por muitas gerações;

b) bactérias endofíticas geneticamente modificadas (EGMs) podem colonizar rapidamente plantas hospedeiras sem causar sintomas de doença;

c) após introdução de EGMs, não há queda na diversidade genética da população natural do hospedeiro;

d) EGMs potencialmente podem ser utilizados como vetores para secretar enzimas e outras proteínas em hospedeiros vegetais. 


\section{CONCLUSÕES GERAIS}

a) os isolados de enterobactérias endofíticas de cacau, cana-de-açúcar, eucalipto, citros e soja foram identificados como pertencentes aos gêneros Enterobacter, Erwinia e Pantoea, sendo este último foi o mais freqüente;

b) os isolados de cacau, citros e eucalipto apresentaram alta especificidade com a planta hospedeira;

c) os isolados de cana-de-açúcar e eucalipto não são clonais, pois exibiram grande diversidade de acordo com a planta hospedeira;

d) foi observada presença de Hafnia endofítica, a qual não tinha sido relatada anteriormente;

e) todos os isolados apresentaram sensibilidade ao antibiótico canamicina, porém a sensibilidade à ampicilina variou de acordo com a planta hospedeira; 
f) a produção de celulase pelos isolados variou segundo a planta hospedeira;

g) análise da diversidade genética por seqüenciamento do rDNA 165 e BOXPCR agrupou a maioria dos isolados em subespécies de Pantoea agglomerans;

h) os isolados endofíticos de eucalipto e soja apresentaram maior diversidade genética;

i) dois isolados endofíticos, um de cacau e outro de citros, foram transformados eficientemente com o plasmídio pPAgfp, que se manteve estável nos dois isolados por 72 gerações in vitro;

j) os dois isolados endofíticos geneticamente modificados (EGMs) foram capazes de colonizar plantas de vinca, e nenhum sintoma de doença foi observado;

k) a diversidade genética da população microbiana natural de vinca não decaiu após a introdução de EGMs. 


\section{REFERÊNCIAS BIBLIOGRÁFICAS}

ALMEIDA, A. C.; LANDSBERG, J. J.; SANDS, P. J.; AMBROGI, M. S.; FONSECA, S.; BARDDALA, S. M.; BERTOLUCCIA, F. L. Needs and opportunities for using a process-based productivity model as a practical tool in Eucalyptus plantations. Forest Ecology and Management, v.193, p.167-177, 2004.

ANDREOTE, F. D.; GULLO, M. J. M.; LIMA, A. O. S.; MACCHERONI, W.; AZEVEDO, J. L.; ARAÚJO, W. L.. Impact of genetically modified Enterobacter cloacae on indigenous endophytic community of Citrus sinensis seedlings. Journal of Microbiology, v.42, p.169-173, 2004.

ARAÚJO, J. M., SILVA, A. C., AZEVEDO, J. L. Isolation of endophytic actinomycetes from roots and leaves of maize (Zea mays L.). Brazilian Archives of Biology Technology, v.43, p.447-451, 2000. 
ARAÚJO, W. L.; MACCHERONI, W.; AGUILAR-VILDOSO, C. I.; BARROSO, P. A. V.; SARIDAKIS, H. O.; AZEVEDO, J. L. Variability and interactions between endophytic bacteria and fungi isolated from leaf tissues of citrus rootstocks Canadian Journal of Microbiology, v.47, p.229-236, 2001.

ARAÚJO, W. L.; MARCON, J.; MACCHERONI, W.; VAN ELSAS, J. D.; VAN VUURDE, J. W .L.; AZEVEDO, J. L. Diversity of endophytic bacterial populations and their interaction with Xylella fastidiosa in citrus plants. Applied and Environmental Microbiology, v.68, p.4906-4914, 2002.

ASIS, C. A.; ADACHI, K. Isolation of endophytic diazotroph Pantoea agglomerans and nondiazotroph Enterobacter asburiae from sweetpotato stem in Japan. Letters in Applied Microbiology, v.38, p. 19-23, 2004.

AZEVEDO, J. L.; MACCHERONI JUNIOR, W.; PEREIRA, J. O.; ARAÚJO, W. L. Endophytic microorganisms: a review on insect control and recent advances on tropical plants. Electronic Journal of Biotechnology, v.3, p.40-65, 2000. 
AZEVEdo, J. L.; MACCHERONI, W.; ARAÚJo, W. L.; PEREIRA, J. O. Microrganismos endofíticos e seu papel em plantas tropicais In: SERAFINI, L. A.; BARROS, N. M.; AZEVEDO, J. L. (Ed.) Biotecnologia: avanços na agricultura e na agroindústria. Caxias do Sul: EDUCS, 2002. Cap.8, p.233268.

BALDANI, J. I.; SALLES, J. F. OLIVARES, F. L. Bactérias endofíticas como vetores de genes de resistência a insetos. In: MELO, S. I.; VALADARESINGLIS, M. C.; NASS, L. L.; VALOIS, A. C. C. (Ed.) Recursos genéticos e melhoramento-microrganismos. Jaguariúna: Embrapa Meio Ambiente, 2002. cap. 22, p.590-601.

BELL, C. R.; DICKIE, G. A. HARVEY, W. L. G.; CHAN, J. W. Y. F. Endophytic bacteria in grapevine. Canadian Journal of Microbiology, v.41, p.46-53, 1995.

BENT, E.; CHANWAY, C. P. The growth-promoting effects of a bacterial endophyte on lodgepole pine are partially inhibited by the presence of other rhizobacteria. Canadian Journal of Microbiology, v.44, p. 980-988, 1998. 
BERG, G.; ROSKOT, B.; STEIDLE, A.; EBERL, L.; ZOCK, A.; SMALLA, K. Plant-dependent genotypic and phenotypic diversity of antagonistic rhizobacteria isolated from different Verticillium host plants. Applied and Environmental Microbiology, v.68, p.3328-3338, 2002.

BERG, G.; KRECHEL, A.; DITZ, M.; SIKORA, R. A.; ULRICH, A.; HALLMANN, J. Endophytic and ectophytic potato-associated bacterial communities differ in structure and antagonistic function against plant pathogenic fungi. FEMS Microbiology Ecology, v.51, p.215-229, 2005.

BERGEY, J. G. H.; KRIEG, N. R.; SNEATH, P. H. A. Bergey's manual of systematic bacteriology. 9.ed. Baltimore: Lippincott Williams \& Wilkins; 1994, 787p.

BODDEY, R. M.; URQUIAGA, S.; ALVES, B. J. R.; REIS, V. Endophytic nitrogen fixation in sugarcane: present knowledge and future applications. Plant and Soil, v.252, p.139-149, 2003.

BURSE, A.; WEINGART, H.; ULLRICH, M. S. NorM, an Erwinia amylovora multidrug efflux pump involved in in vitro competition with other epiphytic bacteria. Applied and Environmental Microbiology, v.70, p.693-703, 2004. 
CARSON, C. A.; SHEAR, B. L.; ELLERSIECK, M. R.; SCHNELL., J. D. Comparison of ribotyping and repetitive extragenic palindromic-PCR for identification of fecal Escherichia coli from humans and animals. Applied and Environmental Microbiology, v.69, p. 1836-1839, 2003.

CHALFIE, M.; RU, Y.; EUSKIRCHEN, G.; WARD, W. W.; PRASHER, D. C. Green fluorescent protein as a marker for gene expression. Science, v.263, p.802-805, 1994.

CHELIUS, M. K.; TRIPLETT, E. W. The diversity of archea and bacteria in association with the roots of Zea mays L. Microbial Ecology, v.41, p.252263, 2001.

CONN, V. M.; FRANCO, C. M. M. Analysis of the endophytic actinobacterial population in the roots of wheat (Triticum aestivum L.) by terminal restriction fragment length polymorphism and sequencing of 16S rRNA clones. Applied and Environmental Microbiology, v.70, p.1787-1794, 2004.

COOMBS, J. T.; MICHELSEN, P. P.; FRANCO, C. M. M. Evaluation of endophytic actinobacteria as antagonists of Gaeumannomyces graminis var. tritici in wheat. Biological Control, v.29, p.359-366, 2004. 
COUTINHO, T. A.; PREISIG, O.; MEgAeRTE, J.; CNOCKAERTE, M. C. RIEDEL, K. H.; SWINGS, J.; WINGFIELD, M. J. Bacterial blight and dieback of Eucalyptus species, hybrids, and clones in South Africa. Plant Disease, v.86, p.20-25, 2002.

COVENTRY, H. S.; DUBERY, I. A. Lipopolysaccharides from Burkholderia cepacia contribute to an enhanced defensive capacity and the induction of pathogenesis-related proteins in Nicotianae tabacum. Physiological and Molecular Plant Pathology. v.58, p.149-158, 2001.

CRUZ, L. M.; SOUZA, E. M.; WEBER, O. B.; BALDANI, J. I.; DOBEREINER, J.; PEDROSA, F. O. 16S ribosomal DNA characterization of nitrogen-fixing bacteria isolated from banana (Musa spp.) and pineapple (Ananas comosus (L.) Merril). Applied and Environmental Microbiology, v.67, p.2375-2379, 2001.

DALZOTO, P. R.; GLIENKE-BLANCO, C.; KAVA-CORDEIRO, V.; ARAUJO, W. L.; AZEVEDO, J. L. RAPD analyses of recombination processes in the entomopathogenic fungus Beauveria bassiana. Mycological Research, v.107, p.1069-1074, 2003. 
DAVELOS, A. L.; KINKEL, L. L.; SAMAC, D. A. Spatial variation in the frequency and intensity of antibiotic interactions among Streptomycetes from prairie soil. Applied and Environmental Microbiology, v.70, p.1051-1058, 2004.

DAVELOS-BAINES, A. L. D.; XIAO, K.; KINKEL, L. L. Spatial differentiation in inhibitory phenotypes contributes to a lack of correspondence between genetic and phenotypic groups among soilborne streptomycetes. FEMS Microbiology 2005 /no prelo/

DESAINT, S.; HARTMANN, A.; PAREKH, N. R.; FOURNIER, J. C. Genetic diversity of carbofuran-degrading soil bacteria. FEMS Microbiology Ecology, v.34, p.173-180 2000.

DI Cello, F., BeVIVINO, A., CHIARINI, L., FANI, R., PAFFETTI, D., TABACCHIONI, S., DALMASTRI, C. Biodiversity of a Burkholderia cepacia population isolated from the maize rhizosphere at different plant growth stages. Applied and Environmental Microbiology, v.63, p.4485-4493, 1997.

DÖBEREINER, J. History and new perspectives of diazotrophs in association with nonleguminous plants. Symbiosis, v.13, p.1-13, 1992. 
DOMBEK, P. E.; JOHNSON, L. K.; ZIMMERLEY, S. T.; SADOWSKY, M. J. Use of repetitive DNA sequences and the PCR to differentiate Escherichia coli isolates from human and animal sources. Applied And Environmental Microbiology, v.66, p.2572-2577, 2000.

DONG, Y.; INIGUEZ, A. L.; AHMER, B. M. M.; TRIPLETT, E. W. Kinetics and strain specificity of rhizosphere and endophytic colonization by enteric bacteria on seedlings of Medicago sativa and Medicago truncatula. Applied and Environmental Microbiology, v.69, p.1783-1790, 2003.

DOWNING, K. J.; LESLIE, G.; THOMSON, J. A. Biocontrol of the sugarcane borer Eldana saccharina by expression of the Bacillus thuringiensis cry $1 A c 7$ and Serratia marcescens chiA genes in sugarcane-associated bacteria. Applied and Environmental Microbiology, v.66, p.2804-2810, 2000.

DOWNING, K. J.; THOMSON, J. A. Introduction of the Serratia marcescens chiA gene into an endophytic Pseudomonas fluorescens for biocontrol of phytopathogenic fungi. Canadian Journal of Microbiology, v.46, p.363$369,2000$. 
DUIJFF, B. J.; GIANINAZZI-PEARSON, V.; LEMANCEAU, P. Involvement of the outer membrane lipopolysaccharides in the endophytic colonization of tomato roots by biocontrol Pseudomonas fluorescens strain WCS417r. New Phytologist, v.135, p.325-334, 1997.

EGENER, T.; HUREK, T.; REINHOLD-HUREK, B. Endophytic expression of nif genes of Azoarcus sp. Strain BH72 in rice roots. Molecular Plant-Microbe Interactions, v. 12, p. 813-819, 1999.

ELBELTAGY, A.; NISHIOKA, K.; SATO, T.; SUZUKI, H.; YE, B.; HAMADA, T.; ISAWA, T.; MITSUI, H.; MINAMISAWA, K. Endophytic colonization and in plant nitrogen fixation by a Herbaspirillum sp. isolated from wild rice species. Applied and Environmental Microbiology, v.67, p.5285-5293, 2001.

EL-TARABILY, K. A. An endophytic chitinase-producing isolate of Actinoplanes missouriensis, with potential for biological control of root rot of lupin caused by Plectosporium tabacinum. Australian Journal of Botany, v. 51, p. 257266, 2003.

ELVIRA-RECUENDO, M.; VAN VUURDE, J. W. L. Natural incidence of endophytic bacteria in pea cultivars under field conditions. Canadian Journal of Microbiology, v.46, p. 1036-1041, 2000. 
ESTRADA, P.; MAVINGUI, P.; COURNOYER, B.; FONTAINE, F.; BALANDREAU, J.; CABALLERO-MELLADO, J. A $\mathrm{N}_{2}$-fixing endophytic Burkholderia sp. associated with maize plants cultivated in Mexico. Canadian Journal of Microbiology, v.48, p.285-294, 2002.

FAHEY, J. W.; DIMOCK, M. B.; TOMASINO, S. F.; TAYLOR, J. M.; CARLSON, P. S. Microbial Ecology of Leaves: genetically engineered endophytes as biocontrol agents: a case study in industry. New York: Springer-Verlag, 1991. p.401-411.

FISHER, P. J.; PETRINI, O.; SCOTT, H. M. L. The distribution of some fungal and bacterial endophytes in maize (Zea mays L.). New Phytologist, v.122, p.299-305, 1992.

FRANKLIN, R. B.; TAYLOR, D. R.; MILLS, A. L. Characterization of microbial communities using randomly amplified polymorphic DNA (RAPD). Journal of Microbiological Methods, v. 35, p. 225-235, 1999.

FROMIN, N.; ACHOUAK, W.; THIÉRY, J. M.; HELIUN T. The genotypic diversity of Pseudomonas brassicacearum populations isolated from roots of Arabidopsis thaliana: influence of plant genotype. FEMS Microbiology Ecology, v.37, p.21-29, 2001. 
GAGE, D. J.; BOBO, T.; LONG, S. R. Use of green fluorescent protein to visualise the early events of symbiosis between Rhizobium meliloti and Alfalfa (Medicago sativa). Journal of Bacteriology, v.178, p.7159-7166, 1996.

GERMAINE, K.; KEOGH, E.; GARCIA-CABELLOS, G.; BORREMANS, B.; VAN DER LELIE, D.; BARAC, T.; OEYEN, L.; VANGRONSVELD, J.; MOORE, F. P.; MOORE, E. R. B.; CAMPBELL, C. D.; RYAN, D.; DOWLING, D. N. Colonisation of poplar trees by gfp expressing bacterial endophytes. FEMS Microbiology Ecology, v.48, p.109-118, 2004.

GISH, F. B.; AMER, E.; FIGUERAS, J. B.; ABELLA, C. A.; BALAGUER, M. D.; $\mathrm{POCH}, \mathrm{M}$. Assessment of microbial community structure changes by amplified ribosomal DNA restriction analysis. International Microbiology, v.3, p.103-106, 2000.

GORIS, J.; BOON, N.; LEBBE, L.; VERSTRAETE, W.; VOS, P. D. Diversity of activated sludge bacteria receiving the 3-chloroaniline-degradative plasmid pC1gfp. FEMS Microbiology Ecology, v.46, p.221-230, 2003. 
GOROKHOVATSKY, A. Y.; MARCHENKOV, V. V.; RUDENKO, N. V.; IVASHINA, T.V.; KSENZENKO, V. N.; BURKHARDT, N.; SEMISOTNOV, G. V.; VINOKUROV, L. M.; ALAKHOV, Y. B. Fusion of Aequorea victoria GFP and aequorin provides their $\mathrm{Ca}(2+)$-induced interaction that results in red shift of GFP absorption and efficient bioluminescence energy transfer. Biochemical and Biophysics Research Communications, v.320, p.703$711,2004$.

GÜRTLER, V.; STANISICH, V. A. New approaches to typing and identification of bacteria using the 16S-23S rDNA spacer region. Microbiology, v.142, p.316, 1996.

GUSSOW, D.; CLACKSON T. Direct clone characterization from plaques and colonies by the polymerase chain reaction. Nucleic Acids Research, v.17, p.4000, 1989.

hAAPALAINEN, M. L.; KOBETS, N.; PIRUZIAN, E.; METZleR, M. C. Integrative vetor for stable transformation and expression of a beta-1,3glucanase gene in Clavibacter xyli subsp. Cynodontis. FEMS Microbiology Letters, v.162, p.1-7, 1998. 
HALLMANN, J.; QUADT-HALLMANN, A.; MAHAFFEE,W. F.; KLOEPPER, J. W. Bacterial endophytes in agricultural crops. Canadian Journal of Microbiology, v.43, p.895-914, 1997.

HANE, B. G.; JAGER,K.; DREXLER, H. G. The Pearson product moment correlation coefficient is better suited for identification of DNA fingerprints profiles than band matching algorithms. Electrophoresis, v.14967-972, 1993.

HAUBEN, L.; VAUTERIN, L.; MOORE, E. R.; HOSTE, B.; SWINGS, J. Genomic diversity of the genus Stenotrophomonas. International Journal of Systematic and Bacteriology, v.49, p.1749-1760, 1999.

HAZEM, A.; MANAR, A. Genetic polymorphism by RAPD-PCR and phenotypic characteristics of isolated thermotolerant Bacillus strains from hot spring sources. Microbiologica, v. 26, p. 249-256, 2003. 
HEYNDRICKX, M.; VAUTERIN, L.; VANDAMME, P.; KERSTERS, K.; DE VOS, P. Applicability of combined amplified ribosomal DNA restriction analysis (ARDRA) patterns in bacterial phylogeny and taxonomy. Journal of Microbiological Methods, v. 26, p. 247-259, 1996.

HINTON, D. M.; BACON, C. W. Enterobacter cloacae is an endophytic symbiont of corn. Mycopathologia, v.129, p.117-125, 1995.

HOFFMANN, H.; ROGGENKAMP, A. Populations genetics of the nomenspecies Enterobacter cloacae. Applied and Environmental Microbiology, v.69, p.5306-5318, 2003.

INIGUEZ, A. L, DONG, Y. M, TRIPLETT, E. W. Nitrogen fixation in wheat provided by Klebsiella pneumoniae 342. Molecular Plant-Microbe Interactions, v.10, p. 1078-1085, 2004.

JACKMAN, S. C.; LEE, H.; TREVORS, J. T. Survival, detection and containment of bacteria. Microbial Releases, v.1, p.125-154, 1992. 
JACKSON, P.; MCRAE, T.; HOGARTH, M. Selection of sugarcane families across variable environments I. Sources of variation and an optimal selection index. Field Crops Research, v.43, p.109-118, 1995.

JEFFERSON, R. A.; CAVANAGH, P. A.; BEVAN, M. W. GUS fusion: betaglucoronidase as a sensitive and versatile gene fusion marker in higher plants. EMBO Journal, v.6, p.3901-3907, 1987.

JIMÉNES, M. B.; FlORES, S. A.; ZAPATA, E. V.; CAMPOS, E. P.; BOUQUELET, S.; ZETENO, E. Chemical characterization of root exudates from rice (Oryza sativa) and their effects on the chemotactic response of endophytic bacteria. Plant Soil, v.29, p.271-277, 2003.

JUKES, T. H.; CANTOR, C. R. Evolution of protein molecules. In: MUNRO, H. N. (Ed.). Mammalian Protein Metabolism. New York: Academic Press, 1969. 121-132p.

KENNEDY, I.R; CHOUDHURY, A.T.M.A.; KECSKES, M.L. Non-symbiotic bacterial diazotrophs in crop-farming systems: can their potential for plant growth promotion be better exploited? Soil Biology and Biochemistry, v.36, p. 1229-1244, 2004. 
KLOEPPER, J. W.; BEAUCHAMP, C. J. A review of issues related to measuring colonization of plant roots by bacteria. Canadian Journal of Microbiology, v.38, p.1219-1232, 1992.

KLOEPPER, J. W.; RODRIGUEZ-KABANA, R.; ZEHNDER, G. W.; MURPHY, J. F.; SIKORA, E.; FERNANDEZ, C. Plant root bacterial interactions in biological control of soilborne diseases and potential extension to systemic and foliar diseases. Australasian Plant Pathology, v.28, p.21-26, 1999.

KOELEMAN, J. G. M.; STOOF, J.; BIESMANS, D. J.; SAVELKOUL, P. H. M.; VANDENBROUCKE-GRAULS, C. M. J. E. Comparison of amplified ribosomal DNA restriction analysis, random amplified polymorphic DNA analysis, and amplified fragment length polymorphism fingerprinting for identification of Acinetobacter genomic species and typing of Acinetobacter baumannii. Journal of Clinical Microbiology, v.36, p.2522-2529, 1998.

KRECHEL, A.; FAUPEL, A.; HALLMANN, J.; ULRICH, A.; BERG, G. Potatoassociated bacteria and their antagonistic potential towards plantpathogenic fungi and the plant-parasitic nematode Meloidogyne incognita (Kofoid \& White) Chitwood. Canadian Jounal of Microbiology, v.48, p.772785, 2002. 
KRISHNAMURTHY, K.; GNANAMANICKAM, S. S. Biological control of sheath blight of rice: induction of systemic resistance in rice by plant-associated Pseudomonas spp. Current Science, v.72, p.331-334, 1997.

KUKLINSKY-SOBRAL, J.; ARAÚJO, W. L.; MENDES, R.; GERALDI, I. O.; PIZZIRANI-KLEINER, A. P.; AZEVEDO, J. L. Isolation and characterization of soybean-associated bacteria and their potential for plant growth promotion. Environmental Microbiology, v.6, p.1244-1251, 2004.

$\mathrm{KUNOH}, \mathrm{H}$. Endophytic Actinomycetes: attractive biocontrol agents. Journal of Genetics and Plant Pathology, v. 68, p. 249-252, 2002.

LACAVA, P. T.; ARAÚJO, W. L.; MARCON, J.; MACCHERONI, W.; AZEVEDO, J. L. Interaction between endophytic bacteria from citrus plants and the phytopathogenic bacteria Xylella fastidiosa, causal agent of citrusvariegated chlorosis. Letters in Applied Microbiology, v.39, p.55-59, 2004.

LAGACÉ, L., PITRE, M., JACQUES, M., ROY, D. Identification of the bacterial community of maple sap by using amplified ribosomal DNA (rDNA) restriction analysis and rDNA sequencing. Applied and Environmental Microbiology,.v.70, p.2052-2060, 2004. 
LANA, T. G. Características genéticas e fisiológicas de Crinipellis perniciosa. 2004. 99p. Tese (Doutorado) - Escola Superior de Agricultura "Luiz de Queiroz", Universidade de São Paulo.

LANOOT, B.; VANCANNEYT, M.; DAWYNDT, P.; CNOCKAERT, M.; ZHANG, J.; HUANG Y.; LIU, Z.; SWINGS, J. BOX-PCR fingerprinting as a powerful tool to reveal synonymous names in the genus streptomyces. emended descriptions are proposed for the species Streptomyces cinereorectus, S. fradiae, S. tricolor, S. colombiensis, S. filamentosus, S. vinaceus and S. phaeopurpureus. Systematic and Applied Microbiology, v.27, p.84-92, 2004.

LATHA, R.; SURYANARAYANAN, T. S.; SWAMINATHAN, M. S. Genetic diversity in Acremonium endophytes isolated from warm-season grasses as revealed by RAPD markers. Journal of Plant Biochemistry and Biotechnology, v, 13, p. 39-42, 2004.

LI, L.; LI, Y.; MENG LIM, T.; PAN, S. Q. Gfp-aided confocal laser scanning microscopy can monitor Agrobacterium tumefaciens cell morphology and gene expression associated with infection. FEMS Microbiology Letters, v.179, p.141-146, 1999. 
LODEWYCKX, C.; VANGRONSVELD, J.; PORTEOUS, F.; MOORE, E. R. B.; TAGHAVI, S.; MEZGEAY, M.; VAN DER LELIE, D. Endophytic bacteria and their potential applications. Critical Reviews in Plant Sciences, v.21, p.583-606, 2002.

LONG, H. H.; FURUYA, N.; KUROSE, D.; TAKESHITA, M.; TAKANAMI, Y. Isolation of endophytic bacteria from Solanum $s p$. and their antibacterial activity against plant pathogenic bacteria. Journal of the Faculty of Agriculture Kyushu University, v.48, p.21-28, 2003.

LOUWS, F. J.; SCHNEIDER, M.; DE BRUIJN, F. J. Assessing genetic diversity of microbes using repetitive sequence-based PCR (rep-PCR). In: TORANZOS, G. (Ed.) Nucleic acid amplification methods for the analysis of environmental samples. Lancaster: Technomic Publishing Company. 1996. p.63-94.

LOUWS, F. J.; RADEMAKER, J. L. W.; BRUIJN, F. J. The three ds of PCRbased genomic analysis of phytobacteria: Diversity, detection and disease diagnosis. Annual Reviews Phytopathology, v. 37, p. 81-125, 1999. 
M'PIGA, P.; BÉLANGER, R. R.; PAULITZ, T. C.; BENHAMOU, N. Increased resistance to Fusarium oxysporum f. sp. radicis-lycopersici in tomato plants treated with the endophytic bacterium Pseudomonas fluorescens strain 6328. Physiological and Molecular Plant Pathology, v.50, p.301-320, 1997.

MAHAFFEE, W. F.; KLOEPPER, J. W.; VAN VUURDE, J. W. L.; VAN DER WOLF, J. M.; VAN DEN BRINK, M. Endophytic colonization of Phaseolus vulgaris by Pseudomonas fluorescens strain $89 \mathrm{~b}-27$ and Enterobacter asburiae strain JM22. In: RYDER, M. H.; STEPHENS, P. M.; BOWEN, G. D. (Ed.) Improving plant productivity in rhizosphere bacteria. Melbourne: CSIRO, 1997. p.180.

MARCON, J. Isolamento e caracterização genética de actinomicetos endofíticos de Citrus spp. e interação com Xyllela fastidiosa. São Paulo 2002, 150p. Tese (Mestrado) - Instituto de Ciências Biomédicas, Universidade de São Paulo.

MARGURRAN, A. E. Ecological diversity and its measurements. Princeton: Princeton University Press, 1998, 179p.

MARI, M.; GUIZZARDI, M.; PRATELLA, G. C. Biological control of gray mold in pears by antagonistic bacteria. Biological Control, v.7, p.30-37, 1996. 
McCULLY, M. E. Niches for bacterial endophytes in crop plants: a plant biologist' s view. Australian Journal of Plant Physiology, v.28, p.983-990, 2001.

McINROY, J. A.; KLOEPPER, J. W. Population dynamics of endophytic bacteria in field - grown sweet corn and cotton. Canadian Journal of Microbiology, v.41, p.895-901, 1995.

MELO, I. S.; SCHNEIDER, R. P.; INGLIS, P. W.; VALADARES-INGLIS, M. C. Biomarcadores e biossensores microbianos. In: MELO, I. S.; VALADARESINGLIS, M. C; NASS, L. L.; VALOIS, A. C. C. (Ed.) Recursos Genéticos e Melhoramento- Microrganismos. cap 7. 2002, p.149-176.

MICHAUD, L.; DI CELLO, F.; BRILLI, M.; FANI, R.; LO GIUDICE, A.; BRUNI, V. Biodiversity of cultivable psychrotrophic marine bacteria isolated from Terra Nova Bay (Ross Sea, Antarctica). FEMS Microbiology Letters, v.230, p.63-71, 2004.

MOCALI, S.; BERTELLI, E.; DI CELLO, F.; MENGONI, A.; SFALANGA, A. VILIANI, F.; CACIOTTI, A. TEGLI, S.; SURICO, G.; FANI, R. Fluctuation of bacteria isolated from elm tissues during different seasons and from different plant organs. Research in Microbiology, v.154, p.105-114, 2003. 
MONTEIRO, P. B.; RENAUDIN, J.; JAGOUEIX-EVEILLARD, S.; AYRES, A. J.; GARNIER, M.; BOVÉ, J. M. Catharanthus roseus, an experimental host plant for the citrus strain of Xylella fastidiosa. Plant Disease, v.85, p.246251, 2001.

MUYZER, G. DGGE/TGGE a method for identifying genes from natural ecosystems. Current Opinion in Microbiology, v.2, p.317-322, 1999.

NAIRN, J. D.; CHANWAY, C. Temporary loss of antibiotic resistance by marked bacteria in the rhizosphere of spruce seedlings. FEMS Microbiology Ecology, v.40, p.167-170, 2002.

NATIONAL COMMITTEE FOR CLINICAL LABORATORY STANDARDS. Performance standards for antimicrobial susceptibility testing. 15.ed. Villanova: NCCLS, 2004. M100-S15.

Neto, P. A. S. P.; AZEVEdo, J. L.; CAETANO, L. C. Microrganismos endofíticos em plantas: status atual e perspectivas. Boletin Latinoamericano y del Caribe de Plantas Medicinales y Aromatica, v.3, p.69-72, 2004. 
NEWMAN, L. A.; REYNOLDS, M. C. Bacteria and phytoremediation: new uses for endophytic bacteria in plants. TRENDS in Biotechnology, v.23, p.6-8, 2005.

OLIVE, D. M.; BEAN, P. Principles and applications of methods for DNA-based typing of microbial organisms. Jounal of Clinical Microbiology, v.37, p.1661-1669, 1999.

OLIVEIRA, A. L. M.; URQUIAGA, S.; DOBEREINER, J.; BALDANI, J. I. The effect of inoculating endophytic N2-fixing bacteria on micropropagated sugarcane plants. Plant Soil, v.242, p.205-215, 2002.

OVREAS, L.; TORSVIK, V. Microbial diversity and community structure in two different agricultural soil communities. Microbial Ecology, v.36, p.303-315, 1998.

PAN, M. J.; RADEMAN, S.; KUNERT, K.; HASTINGS, J. W. Ultrastructural studies on the colonization of banana tissue and Fusarium oxysporum f. sp. cubense race 4 by endophytic bacterium Burkholderia cepacia. Journal of Phytopathology, v.145, p.479-486, 1997. 
PARAN, I.; MICHELMORE, R. W. Development of reliable PCR-based markers linked to downey mildew resistance genes in lettuce. Theoretical and Applied Genetics, v.85, p.985-993, 1993.

PEREIRA J.O.; AZEVEDO, J. L.; PETRINI, O. Endophytic fungi of Stylosanthes: a preliminary study. Mycologia, v.85, p.362-364, 1993.

PEREIRA, J. O.; CARNEIRO-VIEIRA, M. L.; AZEVEDO, J. L. Endophytic fungi from Musa acuminata and their reintroduction into axenic plants. World Journal of Microbiology and Biotechnology, v.15, p.37-40, 1999.

PILLAY, V. K.; NOWAK, J. Inoculum density, temperature and genotype effects on in vitro growth promotion and epiphytic and endophytic colonization of tomato (Lycopersicum esculentum L.) seedlings inoculated with a pseudomonad bacterium. Canadian Journal of Microbiology, v.43, p.354361, 1997.

PLEBAN. S.; CHERNIN, L.; CHET, I. Chitinolytic activity of an endophytic strain of Bacillus cereus. Letters in Applied Microbiology, v.25, p.284-288, 1997. 
PROCÓPIO, R. E. L. Diversidade bacteriana endofítica de Eucalyptus spp. e avaliação do seu potencial biotecnológico. São Paulo 2004, 101p. Tese (Doutorado) - Instituto de Ciências Biomédicas, Universidade de São Paulo.

QUADT-HALLMANN, A.; HALLMANN, J.; KLOEPPER, J.W. Bacterial endophytes in cotton: localization and interaction with other plant-associated bacteria. Canadian Journal of Microbiology, v.43, p.254-259, 1997a.

QUADT-HALLMANN, A.; BENHAMOU, N.; KLOEPPER, J. W. Bacterial endophytes in cotton: mechanisms of entering the plant. Canadian Journal of Microbiology, v.43, p.577-582, 1997b.

QUADT-HALLMANN, A.; KLOEPPER, J. W. Immunological detection and Iocalization of the cotton endophyte Enterobacter asburiae JM22 in different plant species. Canadian Journal of Microbiology, v.42, p.1144-1154, 1996.

RADEMAKER, J. L. W.; DE BRUIJN, F. J. Characterization and classification of microbes by rep-PCR genomic fingerprinting and computer assisted pattern analysis. In: CAETANO-ANOLLÉS, G.; GRESSHOFF, P. M (Ed.) DNA Markers: protocols, applications and overviews, New York: John Wiley, 1997. p.151-171. 
RADEMAKER, J. L. W.; LOUWS, F. J.; DE BRUIJN, F. J. Characterization of the diversity of ecologically important microbes by rep-PCR genomic fingerprinting. In: AKKERMANS, A. D. L.; VAN ELSAS J. D.; DE BRUIJN F. J. (Ed.) Molecular microbial ecology manual, Dordrecht: Kluwer, 1998. cap. 3. p.1-26.

RADEMAKER, J. L. W.;HOSTE, B.;LOUWS, F. J.;KERTERS, K,; SWINGS, J.; VAUTERIN, L.; VAUTERIN, P.; DE BRUJIN, F. J. Comparison of AFLP and rep-PCR genomic fingerprints with DNA-DNA homology studies: Xanthomonas as a model system. International Journal of Systematic and Evolutionary Microbiology, v.50, p.665-677, 2000.

RAMOS, C.; MOLBAK, L.; MOLIN, S. Bacterial activity in the rhizosphere analysed at the single cell level by monitoring ribosome contents and synthesis rates. Applied and Environmental Microbiology, v.66, p.801$809,2000$.

RANJARD, L.; POLY, F.; NAZARET, S. Monitoring complex bacterial communities using culture-independent molecular techniques: application to soil environment. Research in Microbiology, v.151, p.167-177, 2000. 
RAUPACH, G. S.; KLOEPPER, J. W. Mixtures of plant growth-promoting rhizobacteria enhance biological control of multiple cucumber pathogens. Phytopathology, v.88, p.1158-1164, 1998.

REINHOLD-HUREK, B.; HUREK, T. Interactions of gramineous plants with Azoarcus spp. and other diazotrophs: identification, localization and perspectives to study their function. Critical Reviews in Plant Sciences, v.17, p.29-54, 1998.

REITER, B.; BURGMANN, H.; BURG, K.; SESSITSCH, A. Endophytic nifH gene diversity in African sweet potato. Canadian Journal of Microbiology, v.9, p. 549-555, 2003.

RIVERA, A. M. G.; PRIEST, F. G. Molecular typing of Bacillus thuringiensis serovars by RAPD-PCR. Systematic And Applied Microbiology, v. 26, p. 254-261, 2003.

RODAS, A. M.; FERRER, S. PARDO, I. 16S-ARDRA, a tool for identification of lactic acid bacteria isolated from grape must and wine. Systematic and Applied Microbiology, v.26, p.412-422, 2003. 
ROJAS, A.M.; DE LOS RIOS, J.E.G.; SAUX, M.F.L.; JIMENEZ, P.; RECHE, P.; BONNEAU, S.; SUTRA, L.; MATHIEU-DAUDE, F.; MCCLELLAND, M. Erwinia toletana sp nov., associated with Pseudomonas savastanoi-induced tree knots. International Journal of Systematic and Evolutionary Microbiology, v.54, p. 2217-2222, 2004.

RUBINI, M. R., R. T. SILVA-RIBEIRO, A. W. V. POMELLA, C. S. MAKI, W. L. ARAÚJO, D. R. SANTOS, AND J. L. AZEVEDO. Diversity of endophytic fungal community of cacao (Theobroma cacao L.) and biological control of Crinipellis perniciosa, causal agent of Witches' Broom Disease. International Journal of Biological Sciences, v.1, p.24-33, 2005.

SAIKKONEN, K.; WALI, P.; HELANDER, M.; FAETH, S. H. Evolution of endophyte-plant symbioses. Trends in Plant Science, v.9, p.275-280, 2004.

SAITOU, N.; NEI, M. The neighbor-joining method: a new method for reconstructing phylogenetic trees. Molecular Biology and Evolution, v.4, p.406-425, 1987. 
SAMBROOK, J.; FRITSCH, E. F.; MANIATIS, T. Molecular Cloning: a laboratory manual. 2.ed. New York: Cold Spring Harbor Laboratory Press, 1989. 1890p.

SAS INSTITUTE. SAS/STAT guide for personal computers: version 6. Cary, 1989.1686p.

SCHLOTER, M.; LEBUHN, M.; HEULIN, T.; HARTMANN, A. Ecology and evolution of bacterial microdiversity. FEMS Microbiology Reviews, v.24, p.647-660, 2000.

SELANDER, R. K.; CAUGANT, D.A.; OCHMAN, H.; MUSSER, J. M.; GILMOUR, M. N.; WHITTAM, T. S. Methods of multilocus enzyme electrophoresis for bacterial populations genetics and systematics. Applied and Environmental Microbiology, v.51, p.873-884, 1986.

SELOSSE, M. A.; BAUDOIN, E.; VANDENKOORNHUYSE, P. Symbiotic microorganisms, a key for ecological success and protection of plants. Comptes Rendus Biologies, v.327, p.639-648, 2004. 
SESSITSCH, A.; REITER, B.; PFEIFER, U.; WILHELM, E. Cultivationindependent population analysis of bacterial endophytes in three potato varieties based on eubacterial and Actinomycetes-specific PCR of $16 \mathrm{~S}$ rRNA genes. FEMS Microbiology Ecology, v.39, p.3-32, 2002.

SHARMA, V. K.; NOWAK J. Enhancement of verticillium wilt resistance in tomato transplants by in vitro co-culture of seedlings with a plant growth promoting rhizobacterium (Pseudomonas sp. strain PsJN). Canadian Journal of Microbiology, v.44, p.528-536, 1998.

SHISHIDO, M.; BREUIL, C.; CHANWAY, C. P. Endophytic colonization of spruce by growth-promoting rhizobacteria. FEMS Microbiology Ecology, v.29, p.191-196, 1999.

SMIDA, J.; LEIBHARD, S.; NICKEL, A. M.; ECKARDT-SCHUPP, F.; HIEBER, L. Application of repetitive sequence-based PCR (Inter-LINE PCR) for the analysis of genomic rearrangements and for the genome characterization on different taxonomic levels. Genetic Analysis- Biomolecular Engineering, v.13, p.95-98, 1996. 
SOUZA, L. C.; ANDREOTE, F. D.; GULLO, M. J. M.; MACCHERONI, W.; ARAÚJO, W. L.; MONTEIRO-VITORELLO, C. B.; AZEVEDO, J. L. Complete sequence and analysis of a cryptic plasmid from the citrus endophytic bacterium Pantoea agglomerans. Genetics and Molecular Biology, v.23, p.317, 2000.

STACKEBRANDT, E.; GOEBEL, B. M. Taxonomic note: a place for DNA-DNA reassociation and 16S rRNA sequence analysis in the present species definition in bacteriology. International Journal of Systematic Bacteriology, v.44, p.846-849, 1994.

STEEL, R. G. D.; TORRIE, J. H. Principles and procedures of statistics: a biometrical approach. 2 ed. New York:McGraw-Hill, 1980. 631p.

STOLTZFUS, J. R.; SO, R.; MALARVITHI, P. P.; LADHA, J. K.; BRUIJN, F. J. Isolation of endophytic bacteria from rice and assessment of their potential for supplying rice with biologically fixed nitrogen. Plant and Soil, v.194, p.25-36, 1997. 
STURZ, A. V.; CHRISTIE, B. R.; MATHESON, B. G.; ARSENAULT, W. J.; BUCHANAN, N. A. Endophytic bacterial communities in the periderm of potato tubers and their potential to improve resistence to soil-borne plant pathogens. Plant Pathology, v.48, p.360-369, 1999.

STURZ, A. V.; CHRISTIE, B. R.; NOWAK, J. Bacterial endophytes: potential role in developing sustainable systems of crop production. Critical Review in Plant Sciences, v.19, p.1-30, 2000.

STUURMAN, N.; BRAS, C.; SCHLAMAN, H.; WIJFJES, A.; BLOEMBERG, G.; SPAINK, $\mathrm{H}$. Use of green fluorescent protein colour variants expressed on stable broad host range vectors to visualise Rhizobia interacting with plants. Molecular Plant-Microbe Interactions, v.13, p.1163-1169, 2000.

SURETTE, M. A.; STURZ, A. V.; LADA, R. R.; NOWAK, J. Bacterial endophytic in processing carrots (Daucus carota L. var. sativus): their localization, population density, biodiversity and their effects on plant growth. Plant and Soil, v.253, p.381-390, 2003.

SWOFFORD, D.L. (Eds.) Paup*. Phylogenetic Analysis Using Parsimony ( ${ }^{*}$ and Other Methods), Version 4. Sunderland: Sinauer Associates. 2002. 
TAECHOWISAN T.; PEBERDY, J.F.; LUMYONG, S. Chitinase production by endophytic Streptomyces aureofaciens CMUAc130 and its antagonism against phytopathogenic fungi. Annals of Microbiology, v.53, p.447-461, 2003.

TEATHER, R.M.; WOOD, P.J. Use of Congo red-polysaccharide interactions in enumeration and characterization of cellulolytic bacteria from bovine rumen. Applied and Environmental Microbiology, v.43, p.777-780, 1982.

TERASAWA, G. L. V.; GLIENKE, B. C.; HUNGRIA. M. Diversity of a soybean rhizobial population adapted to a cerrados soil. World Journal of Microbiology and Biotechnology, v.19, p.933-939, 2003.

TESTER, C. F. Influence of genetically modified endophytic bacterium on composition and decompositions of corn residue. Soil Biology and Biochemistry, v.24, p.1107-1112, 1992.

THERON, J.; CLOETE, T. E. Molecular techniques for determining microbial diversity and community structure in natural environments. Critical Reviews in Microbiology, v.26, p.37-57, 2000. 
TIGANO, M. S.; ALJANABI, S.; MELLO, S. C. M. Genetic variability of Brazilian Alternaria spp. isolates as revealed by RAPD analysis. Brazilian Journal of Microbiology, v. 34, p. 117-119, 2003.

TOMASINO, S. F.; LEISTER, R. T.; DIMOCK, M. B.; BEACH, R. M.; KELLY, J. L. Field performance of Clavibacter xyli subsp. cynodontis expressing the insecticidal protein gene $\operatorname{cry} I A(c)$ of Bacillus thuringiensis against European corn borer in field corn. Biological Control, v.5, p.442-448, 1995.

TOR, M.; MANTELL, S. H.; AINSWORHT, C. Endophytic bacteria expressing beta-glucuronidase cause false positive in transformation of Discorea species. Plant Cell Reports, v.11, p.452-456, 1992.

VALADARES-INGLIS, M. C.; INGLIS, P. W.; QUEIROZ, P. R.; CASTRO, M. E. B. Genética e biologia molecular de fungos e vírus utilizados no controle biológico. In: MELO, I. S.; VALADARES-INGLIS, M. C; NASS, L. L.; VALOIS, A. C. C. (Ed.) Recursos Genéticos e MelhoramentoMicrorganismos. 2002. cap 18. p.477-518. 
VAN ELSAS, J. D.; DUARTE, G. F.; ROSADO, A. S.; SMALLA, K. Microbiological and molecular biological methods for monitoring microbial inoculants and their effects in the soil environment. Journal of Microbiological Methods, v. 32, p. 133-154, 1998.

VAN LOON L. C.; BAKKER, P. A. H. M.; PIETERSE, C. M. J. Systemic resistance induced by rhizosphere bacteria. Annual Review of Phytopathology. v.36, p.453-483, 1998.

VANDAMME, P.; POT, B.; GILLIS, M.; de VOS, P.; KERSTERS, K.; SWINGS, J. Polyphasic taxonomy, a consensus approach to bacterial systematics. Microbiological Review, v.60, p.407-438, 1996.

VANEECHOUTTE, M. DNA fingerprinting techniques for microorganisms. Molecular Biotechnology, v.6, p.115-142, 1996.

VENTURA, M.; ELLI, M.; RENIERO, R.; ZINK, R. Molecular microbial analysis of Bifidobacterium isolates from different environments by the speciesspecific amplified ribossomal DNA restriction analysis (ARDRA). FEMS Microbiology Ecology, v.36, p.113-121, 2001. 
VERMA, S. C.; LADHA, J. K.; TRIPATHI, A. K.. Evaluation of plant growth promoting and colonization ability of endophytic diazotrophs from deep water rice. Jounal of Biotechnology, v.91, p.127-141, 2001.

WELSH, J.; MCCLELLAND, M. Fingerprinting using PCR with arbitrary primers. Nucleic Acids Research, v.18, p.7213-7218, 1990.

WILLIAMS, J. G. K.; KUBELIK, A. R.; LIVAK, K. J.; TINGEY, S. V. DNA polymorphisms amplified by primers are useful as genetic markes. Nucleic Acids Research, v.18, p.6531-6535, 1990.

WILSON, D. Endophytes: the evolution of a term, and clarification of its use and definition. OIKOS, v.73, p.274-276, 1995.

WISE, M. G.; VAUN MCARTHUR, J.; WHEAT, C.; SHIMKETS, L. J. Temporal variation in genetic diversity and structure of a lotic population of Burkholderia (Pseudomonas) cepacia. Applied and Environmental Microbiology, v.62, p.1558-1562, 1996. 
WOO, P. C. Y.; KENNETH, N. H. L.; LAU, S. K. P.; FUNG, A. M. Y.; LEUNG K. W.; TAM, D. M. W.; QUE, T. L.; YUEN, K. Y. Usefulness of the microseq 50016 s ribosomal dna-based bacterial identification system for identification of clinically significant bacterial isolates with ambiguous biochemical profiles. Journal of Clinical Microbiology, v.41, p.1996-2001, 2003.

YANG, H. H.; VINOPAL, R. T.; GRASSO, D.; SMETS, B. F. High diversity among environmental Escherichia coli isolates from a bovine feedlot. Applied and Environmental Microbiology, v.70, p.1528-1536, 2004.

ZINNIEL, D. K.; LAMBRECHT, P.; HARRIS, N. B.; FENG, Z.; KUCZMARSKI, D.; HIGLEY, P.; ISHIMARU, C. A.; ARUNAKUMARI, A.; BARLETTA, R. G.; VIDAVER, A. K. Isolation and characterization of endophytic colonizing bacteria from agronomic crops and prairie plants. Applied and Environmental Microbiology, v.69, p.2198-2208, 2002. 